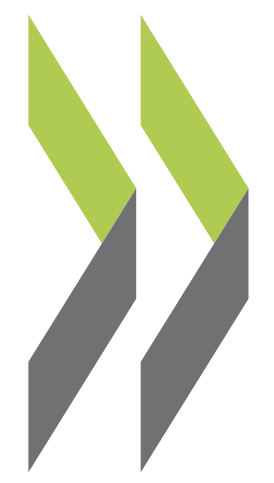

OECD Economics Department Working Papers No. 1572

Fostering Argentina's integration into the world

economy

Robert Grundke, Jens Arnold 


\section{ECONOMICS DEPARTMENT}

\section{FOSTERING ARGENTINA'S INTEGRATION INTO THE WORLD ECONOMY}

\section{ECONOMICS DEPARTMENT WORKING PAPERS No. 1572}

By Robert Grundke and Jens Arnold

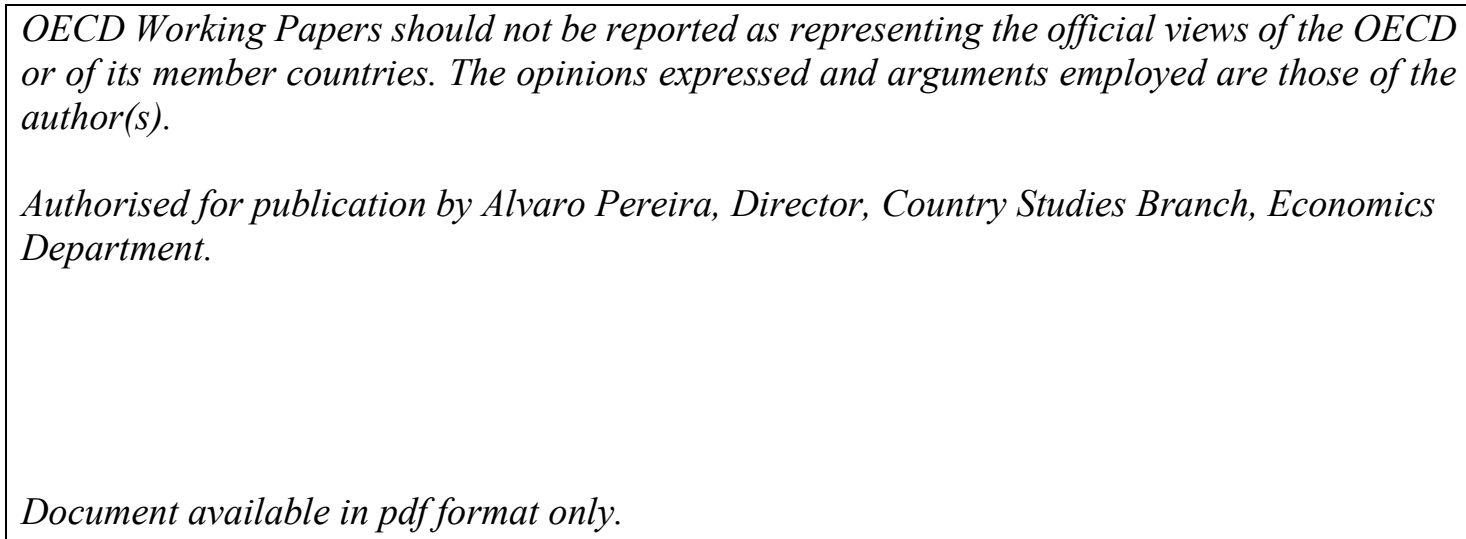
or of its member countries. The opinions expressed and arguments employed are those of the author(s).

Authorised for publication by Alvaro Pereira, Director, Country Studies Branch, Economics Department.

Document available in pdf format only.

All Economics Department Working Papers are available at www.oecd.org/eco/workingpapers.

JT03452691 
OECD Working Papers should not be reported as representing the official views of the OECD or of its member countries. The opinions expressed and arguments employed are those of the author(s).

Working Papers describe preliminary results or research in progress by the author(s) and are published to stimulate discussion on a broad range of issues on which the OECD works.

Comments on Working Papers are welcomed, and may be sent to OECD Economics Department, 2 rue André-Pascal, 75775 Paris Cedex 16, France, or by e-mail to eco.contact@oecd.org.

All Economics Department Working Papers are available at www.oecd.org/eco/workingpapers.

On 25 May 2018, the OECD Council invited Colombia to become a Member. At the time of preparation the deposit of Colombia's instrument of accession to the OECD Convention was pending and therefore Colombia does not appear in the list of OECD Members and is not included in the OECD zone aggregates.

This document and any map included herein are without prejudice to the status of or sovereignty over any territory, to the delimitation of international frontiers and boundaries and to the name of any territory, city or area.

The statistical data for Israel are supplied by and under the responsibility of the relevant Israeli authorities. The use of such data by the OECD is without prejudice to the status of the Golan Heights, East Jerusalem and Israeli settlements in the West Bank under the terms of international law.

\section{(C) OECD (2019)}

$\overline{\text { You can copy, download or print OECD content for your own use, and you can include }}$ excerpts from OECD publications, databases and multimedia products in your own documents, presentations, blogs, websites and teaching materials, provided that suitable acknowledgment of OECD as source and copyright owner is given. All requests for commercial use and translation rights should be submitted to rights@oecd.org. 


\section{Table of Contents}

Fostering Argentina's integration into the world economy ........................................................................ 6

Argentina has not shared in the benefits of international trade ..................................................... 8

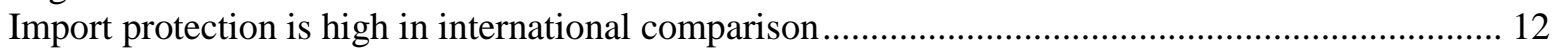

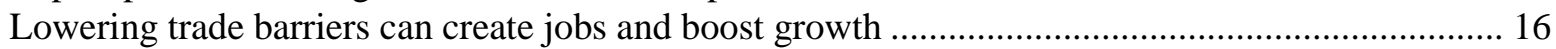

Trade policy options for fostering stronger integration into the global economy............................ 33

Easing the transition: Policies to support the structural transformation ............................................ 40

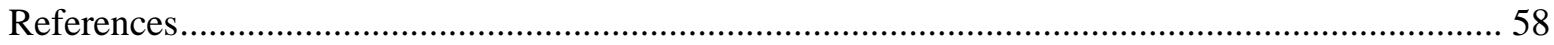

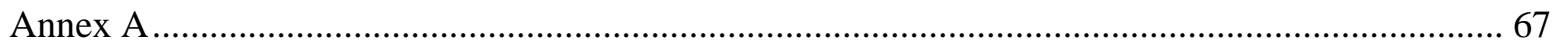

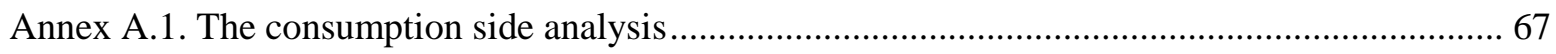

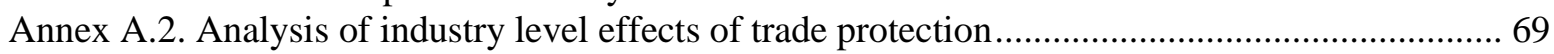

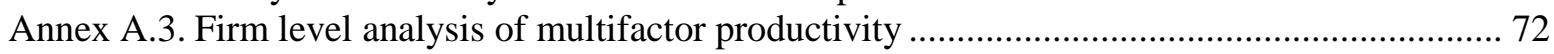

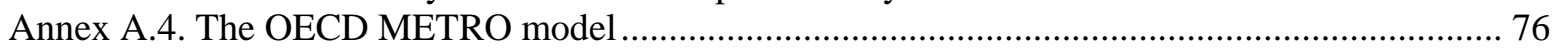

Annex A.5. The effects of import protection on foreign direct investment ..................................... 79

\section{Tables}

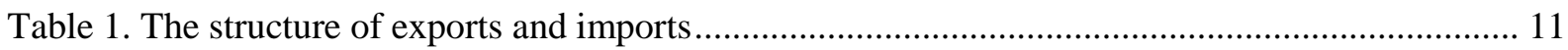

Table 2. Effects of average input tariffs on economic activity (within economic sectors) ................... 19

Table 3. Effects of average input tariffs on economic activity (across economic sectors).................... 21

Table 4. Effects of output tariffs on economic activity (within economic sectors) ................................ 23

Table 5. Effects of output tariffs on economic activity (across economic sectors) ............................... 24

Table 6. Unilateral tariff decreases would boost production in agricultural and some manufacturing

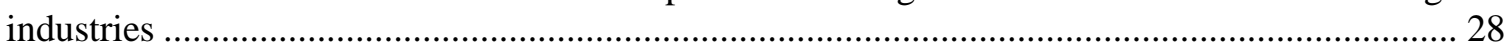

Table 7. Pharmaceuticals and medical devices from Argentina have difficulties to enter the US

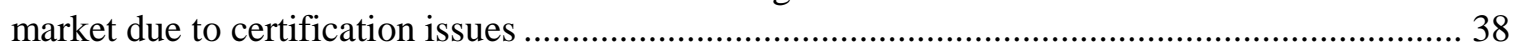

Table 8. Some food products from Argentina have difficulties to enter the EU markets due to non-

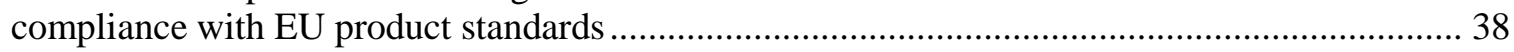

Table 9. Retraining needs are mostly limited to task-specific skills ................................................. 45

Annex Table A.1. Effects of output tariffs on economic activity (within economic sectors) -

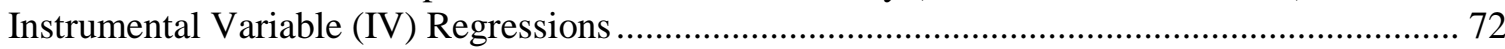

Annex Table A.2. The productivity of firms depends on skills, international integration, innovation, access to credit, infrastructure and the regulatory environment ................................................ 75

Annex Table A.3. Correlates of firm's total factor productivity for Argentinian firms ........................ 75

Annex Table A.4. Unilateral tariff cuts would decrease input prices in many industries ..................... 78

Annex Table A.5. Unilateral tariff cuts would lead to sectoral reallocation of workers ....................... 79

Annex Table A.6. FDI Flows are oriented to the domestic market .................................................... 80

\section{Figures}

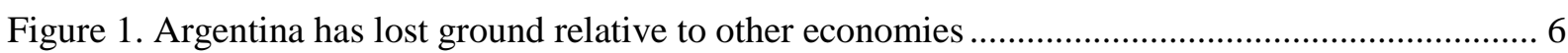

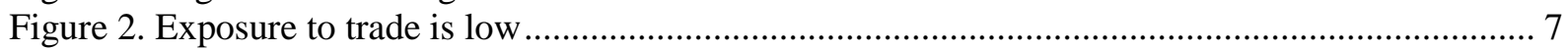

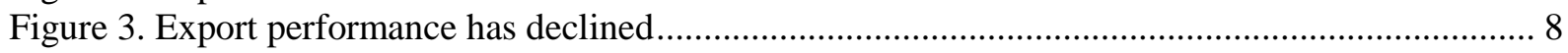

Figure 4. Argentina's' integration into global value chains is low....................................................... 9

Figure 5. Argentina has remained on the sidelines of global value chains.......................................... 10 


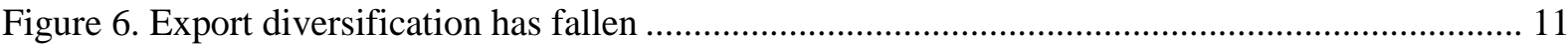

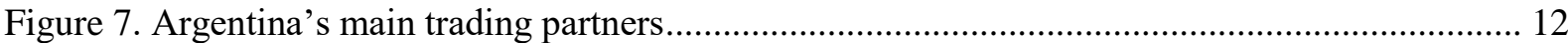

Figure 8. Tariff protection is high, especially for capital goods and intermediate inputs ..................... 13

Figure 9. Many industries are protected through high import tariffs ................................................... 14

Figure 10. Non-automatic import licenses are required in many industries ........................................ 15

Figure 11. Domestic producers play a dominant role in many tradable sectors ................................... 15

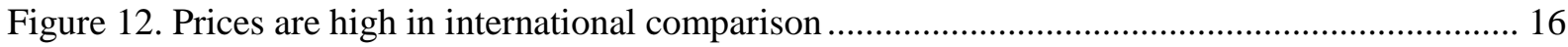

Figure 13. Potential consumer benefits from lower trade barriers are progressive ............................... 17

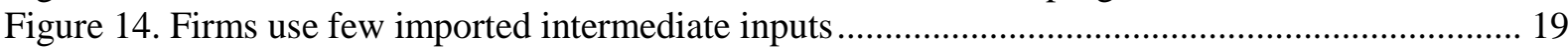

Figure 15. Reducing input tariffs boosts economic activity and exports ........................................... 20

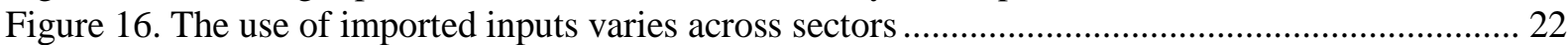

Figure 17. Decreasing output tariffs boosts productivity, but can reduce employment in a few

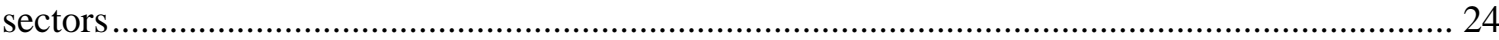

Figure 18. Productivity is low in sectors with high trade protection................................................. 25

Figure 19. Protected sectors have dispersed productivity and low allocative efficiency ...................... 26

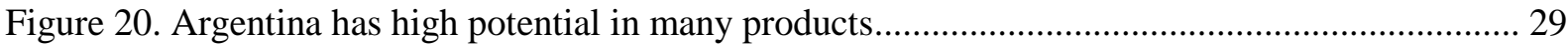

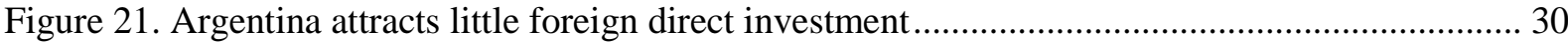

Figure 22. Stock of foreign direct investment by sector in 2017 (in Million USD) ............................. 32

Figure 23. Argentina's services exports face high barriers in its main current and potential export

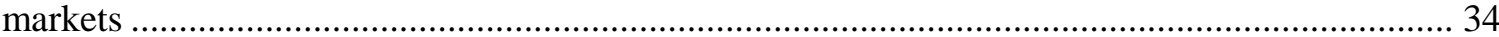

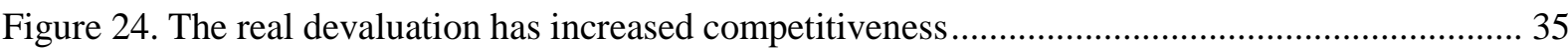

Figure 25. Argentina's products face issues with product standard regulations in its main export

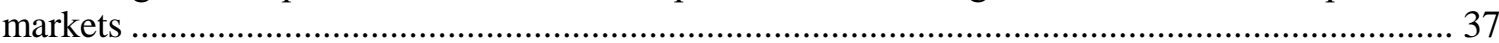

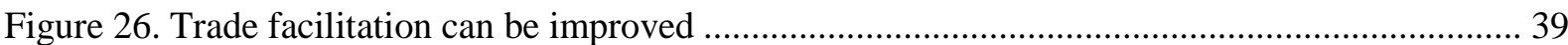

Figure 27. Spending on active labour market policies is below the OECD average ............................ 43

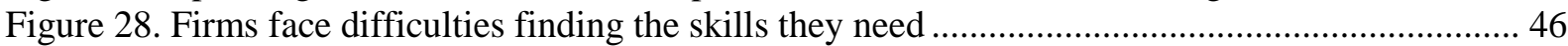

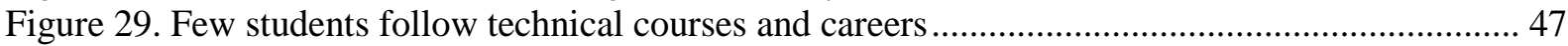

Figure 30. There is room to reduce the restrictiveness of product market regulations.......................... 49

Figure 31. Product market regulations could allow more room for competition .................................. 50

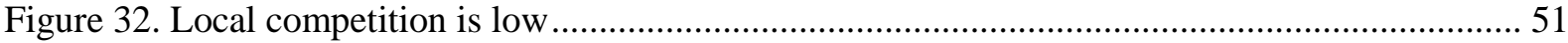

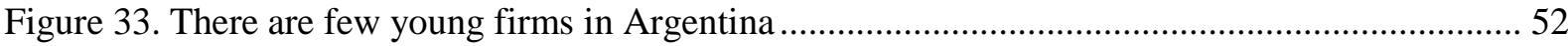

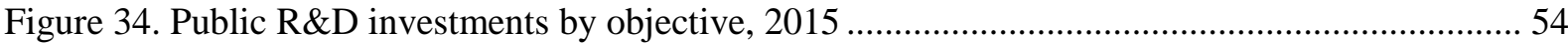

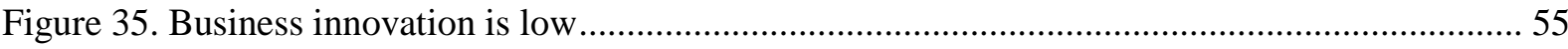

Annex Figure A.1. Potential consumer benefits from lowering trade barriers by $50 \%$....................... 69

\section{Boxes}

Box 1. Product standards and their enforcement might pose significant barriers to Argentina's exports to advanced economies

Box 2. Successful examples of policies to complement the structural transformation .......................... 41

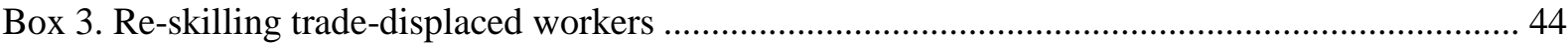

Box 4. Recommendations to foster integration into the world economy ............................................. 57 


\section{ABSTRACT/RÉSUMÉ \\ Fostering Argentina's integration into the world economy}

Ever since the early 20th century, Argentina has failed to fully reap the benefits that integrating into the world economy can offer. With exports and imports only accounting for less than 30\% of GDP, Argentina is significantly less integrated into the world economy than other emerging market economies. This reflects several decades of inward oriented policies including a strategy of industrialisation through import substitution. Trading little, Argentina has also remained on the side-lines of global value chains, all of which represents significant lost opportunities for growth and well-being. This paper, based on a chapter in the 2019 Economic Survey of Argentina, analyses the potential benefits and distributional effects of a stronger integration into the global economy. It also discusses policy options for opening up and for accompanying policies to ease the transition towards a more open economy.

This Working Paper relates to the 2019 OECD Economic Survey of Argentina

http://www.oecd.org/economy/argentina-economic-snapshot/

JEL classification codes: F13, F14, F16

Keywords: International trade, empirical trade analysis, trade openess, Argentina, adjustment costs, factor reallocation, domestic distortions

\section{Favoriser l'intégration de l' Argentine dans l'économie mondiale}

Depuis le début du XXe siècle, l'Argentine n'a pas pleinement exploité les avantages que l'intégration à l'économie mondiale peut offrir. Les exportations et les importations représentant moins de 30\% du PIB, l'Argentine est nettement moins intégrée à l'économie mondiale qued'autres économies émergentes. Cela reflète plusieurs décennies de politiques orientées vers l'intérieur, y compris une stratégie d'industrialisation par substitution des importations. Ainsi, l'Argentine est également restée en marge des chaînes de valeur mondiales, ce qui représente toutes des opportunités perdues en termes de croissance et de bien-être. Ce document, basé sur un chapitre de l'Étude Économique de l'Argentine de 2019, analyse les avantages et les effets distributifs d'une intégration plus poussée. Il aborde également les options politiques en matière d'ouverture et les politiques d'accompagnement destinées à faciliter la transition vers une économie plus ouverte.

Ce Document de travail se rapporte à l'Étude économique de l'OCDE de l'Argentine 2019

http://www.oecd.org/frleconomie/argentine-en-un-coup-d-oeil/

Codes de classification JEL : F13, F14, F16

Mots-clés : Commerce international, analyse empirique des relations commercials, ouverture commerciale, Argentine, coûts d'ajustement, réaffectation des facteurs de production, distorsions intérieures 


\title{
Fostering Argentina's integration into the world economy
}

\author{
By Robert Grundke and Jens Arnold ${ }^{1}$
}

Argentinas' growth performance has been weak since the 1950s as the economy has been held back by weak policy settings (Figure 1). Recurrent fiscal crises, monetary financing of fiscal deficits and the weakness of external accounts have lead to macroeconomic instability and disappointing growth performance. High volatility has weighed on investment, distorted saving decisions and curbed the development of domestic capital markets.

\section{Figure 1. Argentina has lost ground relative to other economies}

$$
\text { GDP per capita }
$$

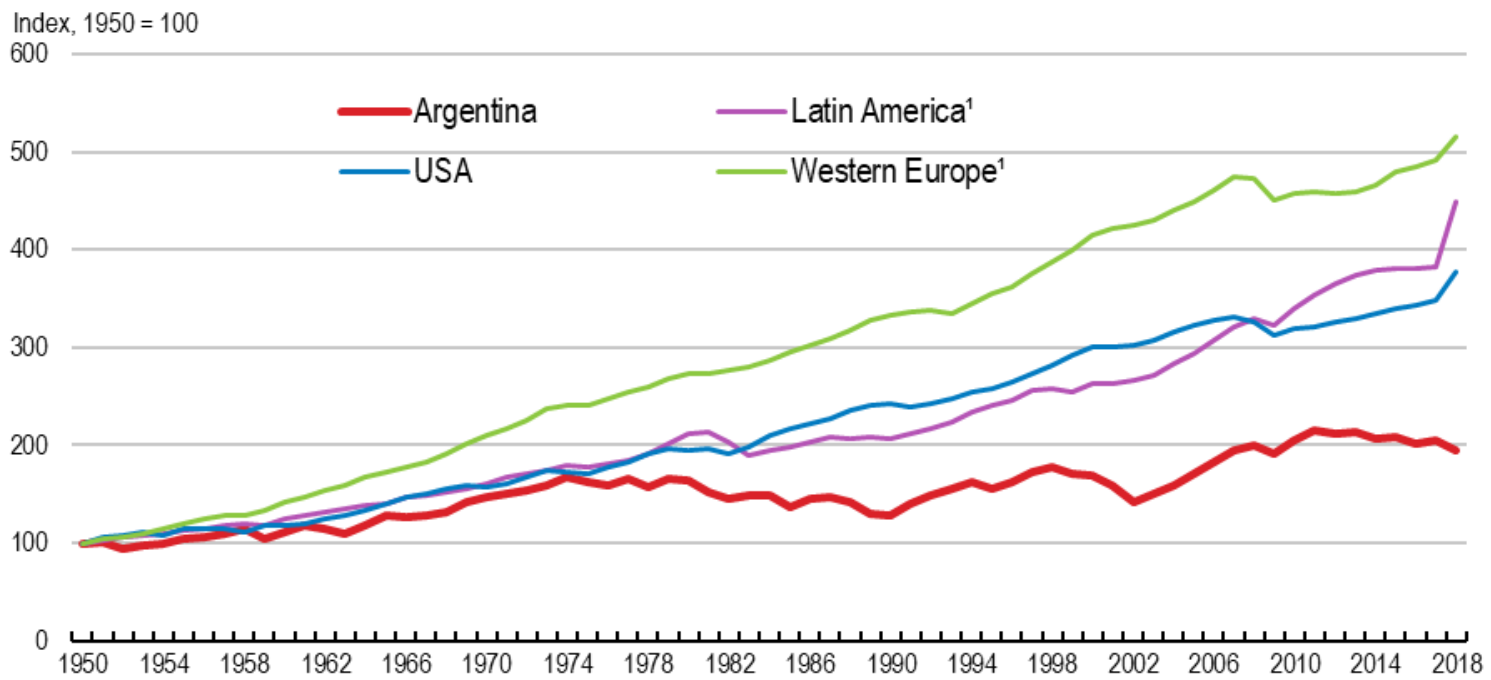

Note 1: Western Europe includes: Austria, Belgium, Denmark, Finland, France, Germany, Greece, Ireland, Italy, Netherlands, Norway, Portugal, Spain, Sweden, Switzerland and United Kingdom; Latin America includes: Brazil, Chile, Colombia, Mexico and Peru.

Source: OECD calculations based on Bolt and Van Zanden (2014) (see http://www.ggdc.net/maddison/maddison-project/data.htm).

Argentina's policies towards international trade have also been characterised by large swings. After participating actively in international trade at the beginning of the 20th century, with exports focused on commodities, inward-focused policies took over as of the 1930s. These were based on the attempt to develop an industrial sector through import substitution at the expense of agriculture. After a drop of real per capita incomes of over

${ }^{1}$ Robert Grundke is Economist and Jens Arnold Principal Economist in the OECD Economics Department. This working paper benefitted from comments from David Haugh and Sahra Sakha as well as participants of the Economic Development Review Committee (EDRC). Special thanks are due to Anne Legendre for statistical support and Assa Fofana and Carolina Gonzalez for editorial support. Financial support for this project from the European Commission through the EU Facility for Development in Transition in Latin America and the Caribbean is gratefully acknowledged. 
$20 \%$ between 1970 and 1990, import tariffs were lowered to some extent and foreign investment inflows surged. The economy returned to growth after 1990 in the context of a currency pegged to the US dollar and falling inflation. However, the exchange rate became increasingly misaligned and export competitiveness declined over the course of the decade, and by the late 1990s the economy was facing a severe recession. Rising fiscal imbalances led to the 2001 debt default and the end of the currency peg. The subsequent massive devaluation wiped out large amounts of household savings held in domestic currency, adding to the impoverishing effect of the crisis. Policies then turned more inward again, including renewed attempts of building up domestic industries through import substitution. Today, Argentina is significantly less integrated into the world economy than other emerging market economies of similar size (Figure 2). Trading little, Argentina has also remained on the sidelines of global value chains and productivity growth has been low, and even negative over the last decade.

Figure 2. Exposure to trade is low

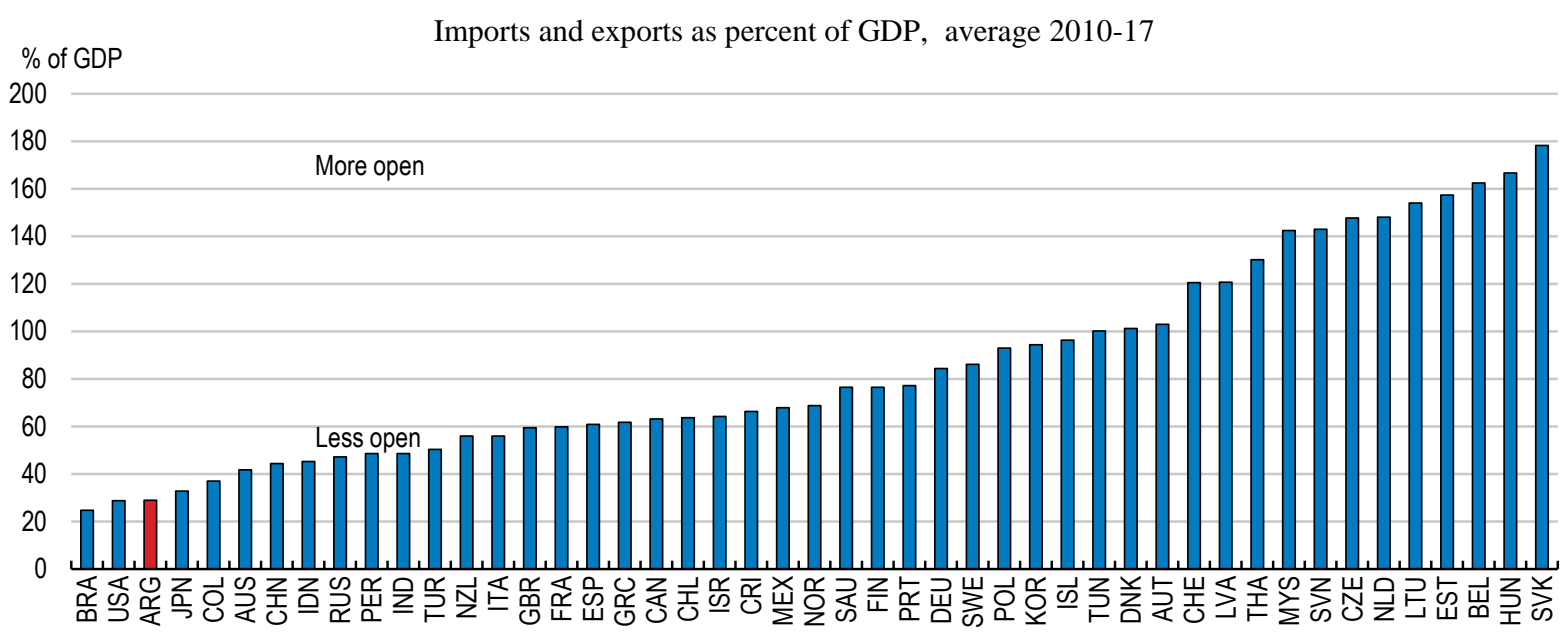

Notes: Larger economies typically show smaller trade to GDP ratios because they trade more with themselves (i.e. more intensive internal trade in intermediate inputs and final goods). Argentina shows the lowest trade to GDP ratio among the smaller economies.

Source: IMF World Economic Outlook; OECD Economic Outlook database.

StatLink त्गाड़ http://dx.doi.org/10.1787/888933942999

The only way for incomes to rise in a sustainable manner is that firms and workers find new ways to become more productive. In light of the productivity benefits that other emerging market economies have reaped from their stronger integration into the global economy, tapping into the unexploited potential of international trade presents probably Argentina's best opportunity to achieve higher living standards.

Both consumers and producers can benefit from stronger integration into the global economy and the opportunities it creates. For producers, the access to cheaper and higher quality inputs and capital goods leads to significant productivity gains and stronger competitiveness, which is the basis for improvements in real wages (Amiti and Konings, $2007_{[1]}$; Goldberg et al., 2009 $\left.{ }_{[2]}\right)$. For consumers, trade has potential to reduce prices and enlarge the variety and quality of available goods, which improves particularly the purchasing power of low-income households. 
Embracing the global economy will introduce a much-needed boost of competition into the economy that will raise incentives for enhancing productivity and trigger important structural changes. In this transition, complementary policies can play an important role to ensure that all Argentinians benefit from the positive effects of integration and to mitigate the adjustment costs it creates for workers (Winters, Mcculloch and Mckay, 2004 $4_{[3]}$; Goldberg and Pavcnik, 2007 $\left.{ }_{[4]}\right)$. These adjustment costs can arise particularly in importcompeting sectors, as jobs are shed in low productivity firms and shift towards new or high productivity firms or even new sectors. Most importantly, this calls for supporting workers with targeted education and training programmes to address future skill needs, but also ensuring effective social protection for all, including those who currently work in the informal sector.

Well-designed policies can also go a long way to support the structural transformation of the economy by reducing frictions on labour markets, improving infrastructure, reducing tax distortions and encouraging innovation. Moreover, further reducing barriers to competition on product markets is crucial, as Argentina still has the highest barriers to entrepreneurship among countries covered by the latest revision of the OECD Product Market Regulation (PMR) Indicators. This paper evaluates the opportunities and consequences of an increasing integration into the world economy for Argentina and discusses policy options to support this trajectory.

\section{Argentina has not shared in the benefits of international trade}

Export performance, which measures how exports have grown relative to the overall growth of Argentina's export markets, has been worsening persistently since 2005 (Figure 3). This contrasts with Mexico, for example, whose policies have actively favoured participation in international trade and global value chains.

Figure 3. Export performance has declined

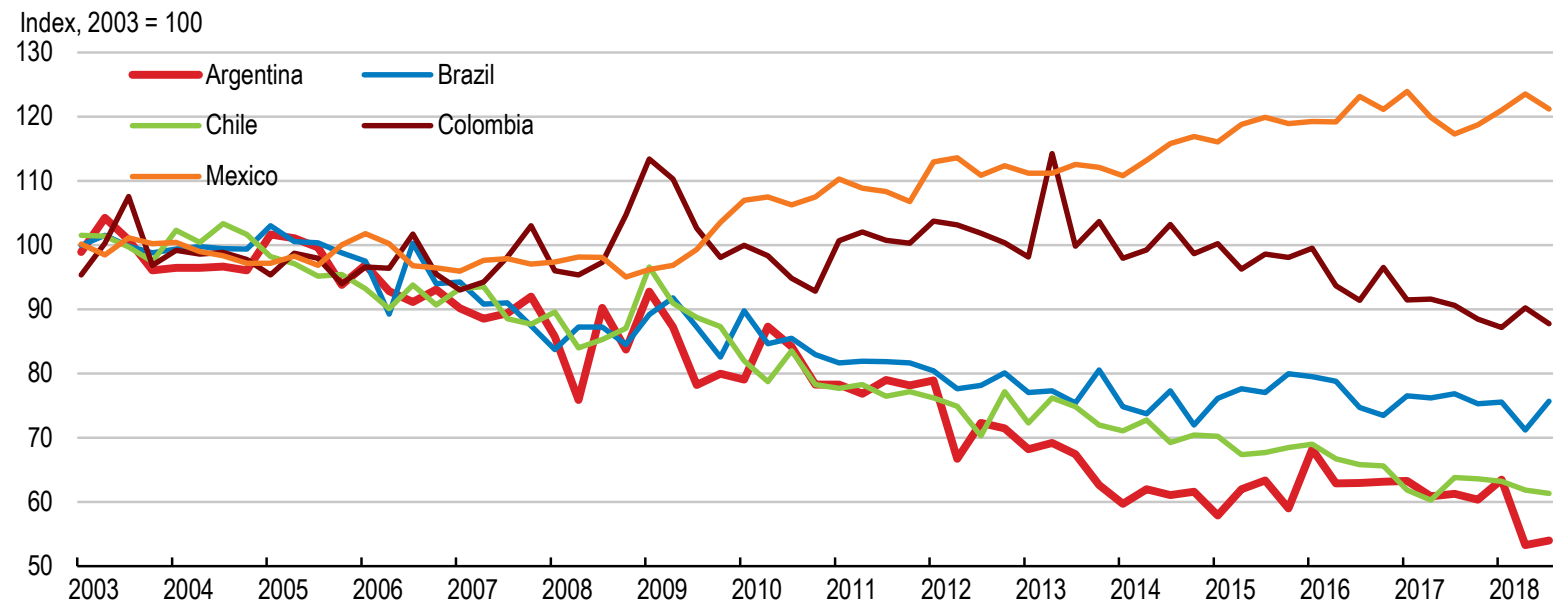

Note: Export performance is measured as actual growth in exports relative to the growth of the country's export markets, which represents the potential export growth for a country assuming that its market shares remain unchanged.

Source: OECD Economic Outlook database. 
Argentina is one of the least integrated economies in global value chains (Figure 4). A small share of domestic value added is exported, i.e. its forward integration into global chains is low. In addition, the low value of the backward integration index shows that firms make little use of foreign intermediate goods and services as well as foreign capital goods, likely one of the main reasons for the low export performance of firms.

Figure 4. Argentina's' integration into global value chains is low

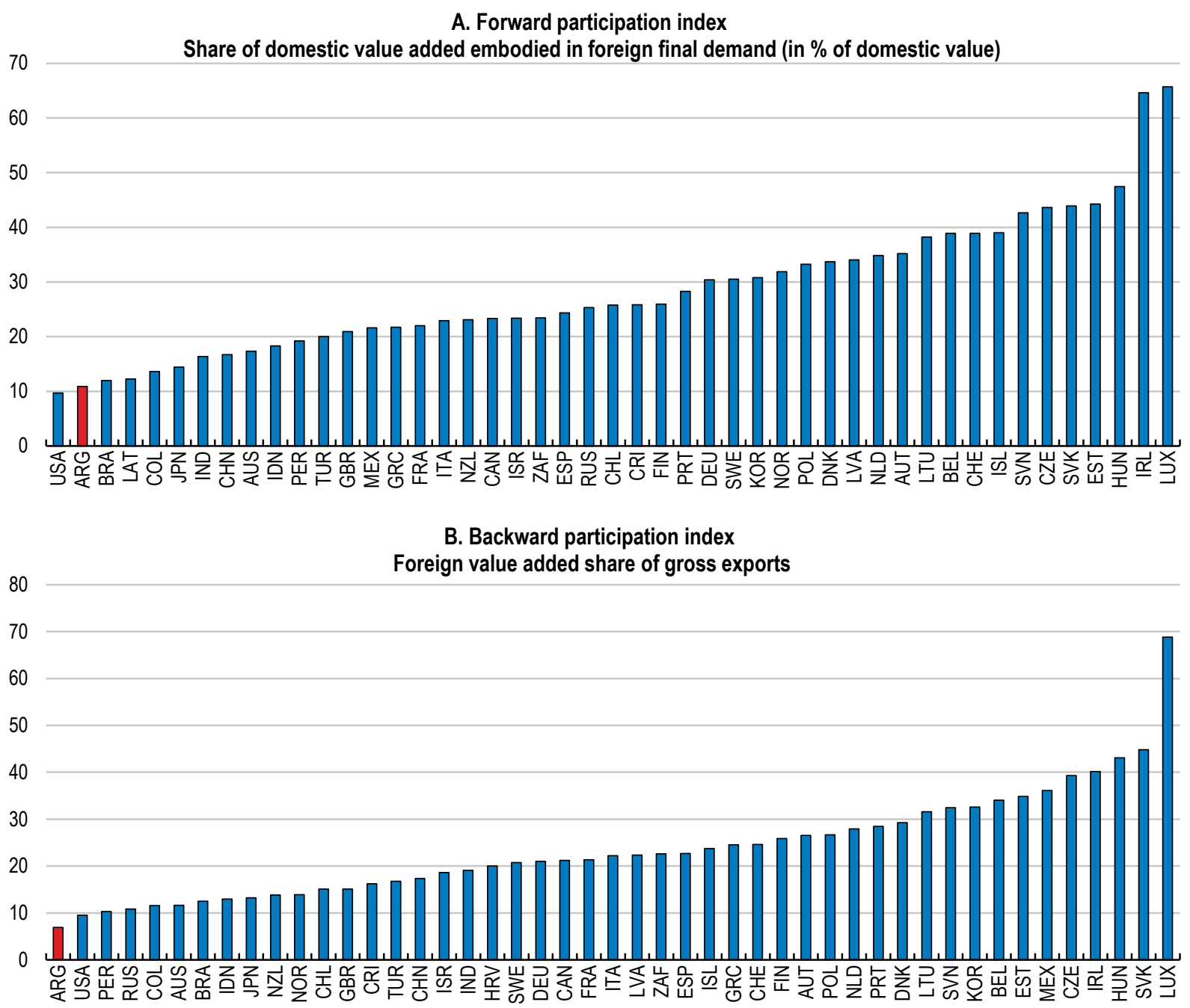

Note: Larger economies typically show smaller participation in global value chains and international trade. Source: OECD Trade in Value Added (TiVA) data base (September 2018).

\section{StatLink त्ञाजी https://doi.org/10.1787/888933943037}

A simplified mapping of trade flows within the context of global value chains suggests that Argentina's only discernible value chain link is with neighbouring Brazil (Figure 5). By contrast, many Asian and European economies are tightly intertwined through their trade relationships, both among themselves and with other advanced economies. Remoteness with respect to international manufacturing hubs, weak transport infrastructure and trade 
policies can all help to explain the low integration of Latin American economies into global value chains (Cadestin, Gourdon and Kowalski, 2016 $\left.{ }_{[5]}\right)$.

Figure 5. Argentina has remained on the sidelines of global value chains

A map of global value chains

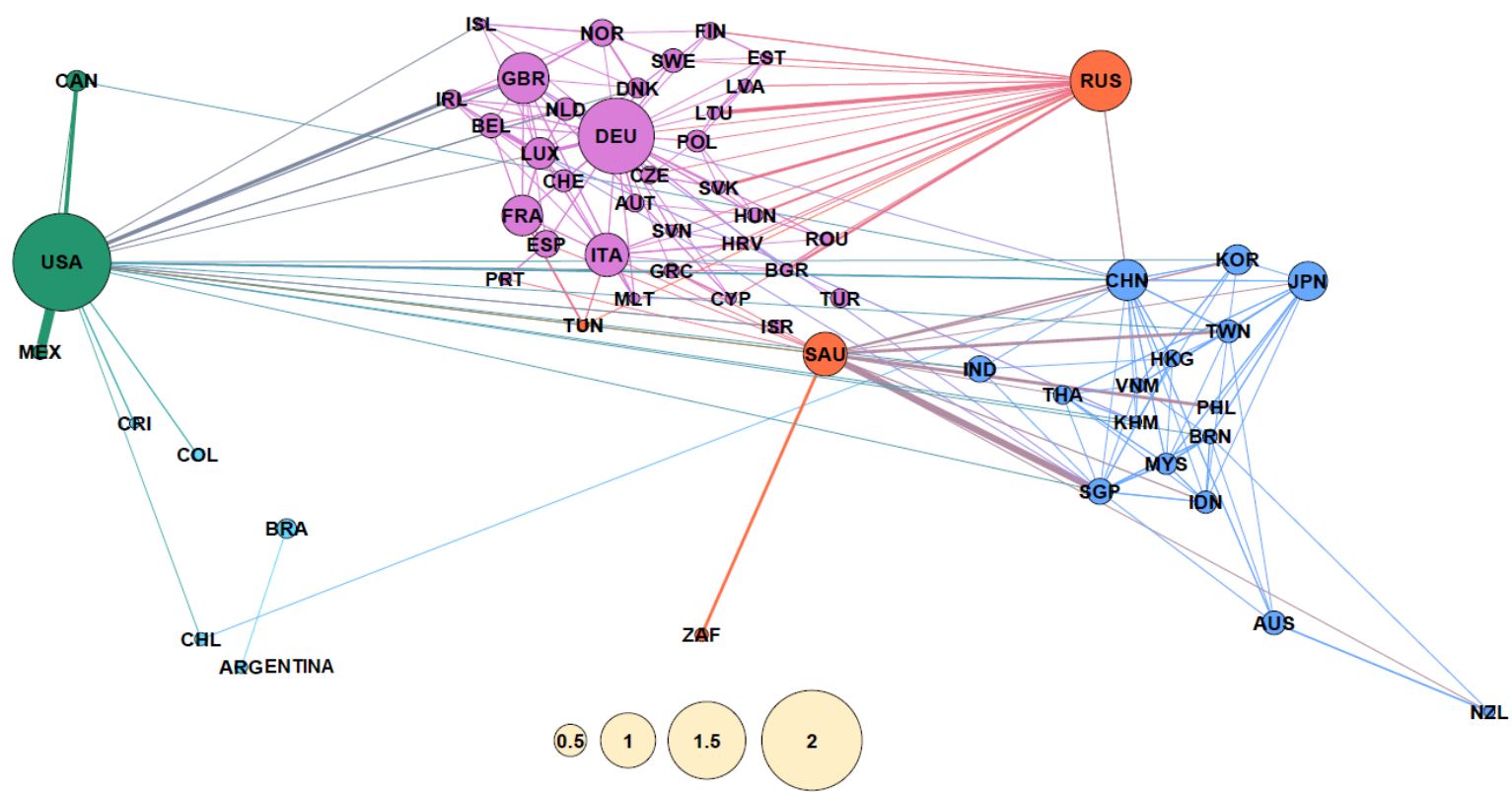

Note: A larger circle reflects an economy that is more connected within global production networks. A line reflects input flows exceeding $2 \%$ of total inputs used in the importing or exporting economy.

Source: (Criscuolo and Timmis, 2018[6]).

Argentina's export structure is dominated by agricultural commodities, which account for around $48 \%$ of all merchandise exports, and processed food products with around $17 \%$. Argentina is the world's largest exporter of soybean meal and soybean oil, which together with soybeans account for $27 \%$ of total exports (Table 1). Other important agricultural export products are corn and wheat (11\% of exports), bovine meat $(2.2 \%)$, crustaceans $(2.1 \%)$, and wine $(1.3 \%)$. Major manufacturing exports include motor vehicles $(8 \%$ of exports), which are predominantly exported to neighbouring Brazil, although exports to other Latin American markets have increased in recent years. Main imports comprise motor vehicles and parts, petroleum oil and gases, electrical and office equipment, machinery and parts, and pharmaceuticals. 
Table 1. The structure of exports and imports

10 main exported and imported goods in 2017 (in \% of total merchandise exports and imports, respectively)

\begin{tabular}{lrlr}
\hline \multicolumn{1}{c}{$\begin{array}{c}\text { Exports (in \% of total merchandise } \\
\text { exports) }\end{array}$} & \multicolumn{2}{c}{ Imports (in \% of total merchandise imports) } \\
\hline Soybean meal & 15.6 & Motor cars and other motor vehicles & 9.4 \\
Corn & 6.7 & Parts and accessories for motor vehicles & 4.2 \\
Soybean oil & 6.4 & Electrical apparatus for line telephony or line telegraphy & $3.4 \mathrm{~s}$ \\
Motor vehicles for the transport of goods & 5.6 & Petroleum gases and other gaseous hydrocarbons & 3.3 \\
Soybeans & 4.7 & Motor vehicles for the transport of goods & 3.1 \\
Wheat & 4.0 & Petroleum oils, other than crude petroleum & 3.0 \\
Gold & 3.9 & Automatic data processing machines and parts thereof & 2.0 \\
Motor cars and other motor vehicles & 2.6 & Medicaments & 1.9 \\
Prepared binders for foundry moulds or & 2.2 & Parts for machinery & 1.9 \\
cores & & & \\
Crustaceans & 2.1 & Other aircraft (for example, helicopters, aeroplanes); & 1.6 \\
& & spacecraft & \\
\hline
\end{tabular}

Source: OECD calculations based on WITS data for merchandise exports and imports.

Overall, the diversification of merchandise exports has fallen during the last decade (Figure 6). This partly reflects rising exports of soybeans, soybean oil and meal, a trend that has been more pronounced than in other Latin American economies. Main export destinations are Brazil, the EU, China and the U.S., which are also the four main import partners (Figure 7). Besides Brazil, Argentina trades relatively little with other Latin American countries, reflecting both a lack of bilateral agreements beyond Mercosur and infrastructure weaknesses.

\section{Figure 6. Export diversification has fallen}

\section{Number of exported products}

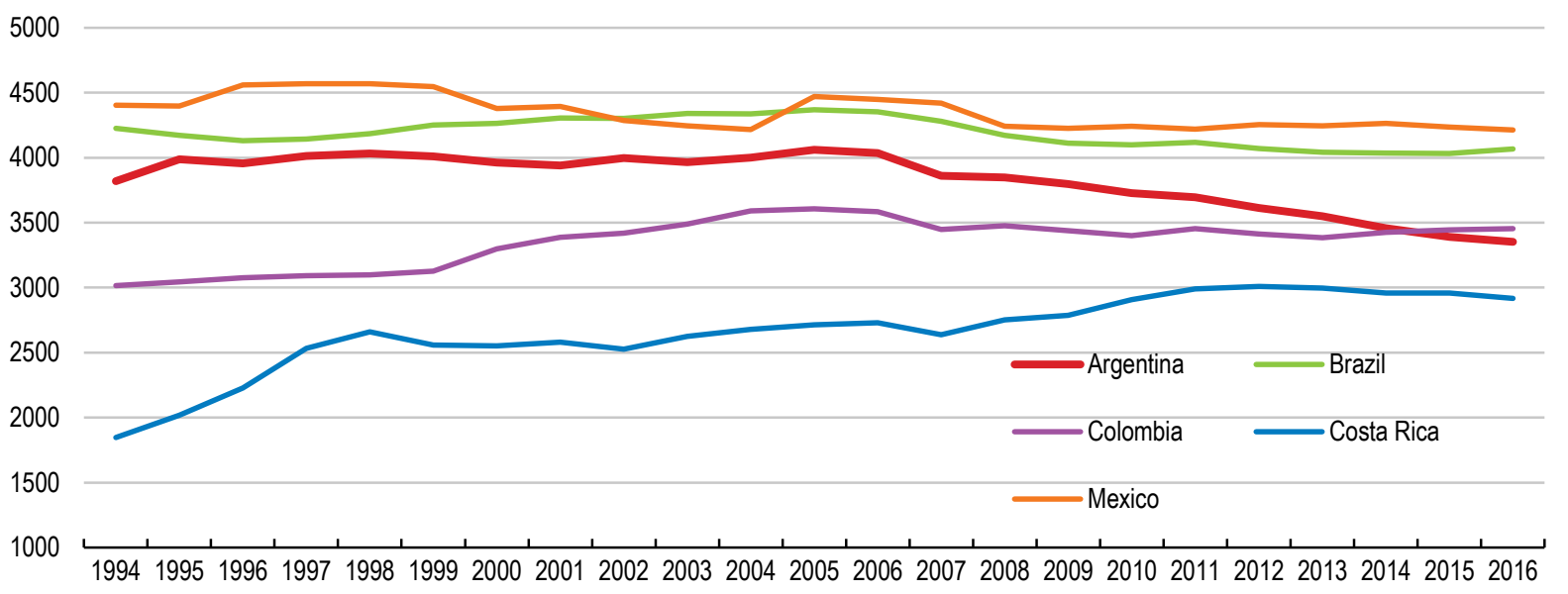

Note: A product is defined as a 6-digit product category in the Harmonised System (HS) product classification. Source: WITS database (2018). 
Figure 7. Argentina's main trading partners
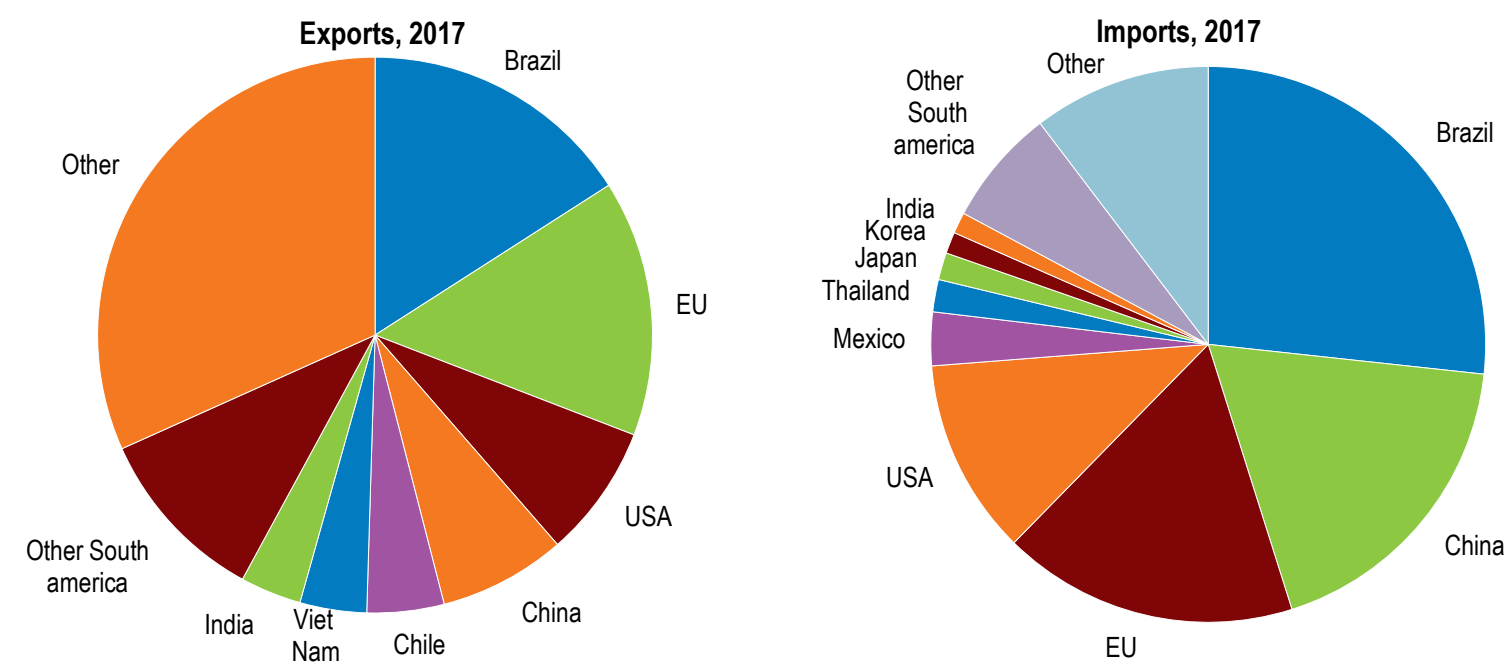

Source: OECD calculations based on WITS data.

StatLink 제패 http://dx.doi.org/10.1787/888933942562

Beyond merchandise exports, exports of knowledge-based services have increased from the late 1990s until 2017 (Gayá, 2017 $[7]$ ). They account for almost 9\% of total exports in goods and services and comprise mostly business, professional and technical services as well as software and computer services (including audio-visual services). Main services export destinations are the US (41\%) and the European Union (26\%), but also other Latin American countries (Gayá, 2017 $\left[{ }_{[7]}\right)$. Imports of knowledge based services have also risen, mostly as intermediate inputs into the production of goods and services, amounting to around $8 \%$ of imports in goods and services.

\section{Import protection is high in international comparison}

The main reason for Argentina's low integration into the world economy and global value chains are high tariffs and non-tariff trade barriers, which increase the costs of imports substantially.

\section{Tariffs are high}

Tariffs are not only high on average, but they also affect intermediate inputs and capital goods, raising production costs across the economy (Figure 8). In other words, tariff protection not only raises consumer prices, it also hurts the competitiveness and productivity of firms and their ability to create jobs. 
Figure 8. Tariff protection is high, especially for capital goods and intermediate inputs

Average applied tariffs by product class for the year 2017 (in \%)
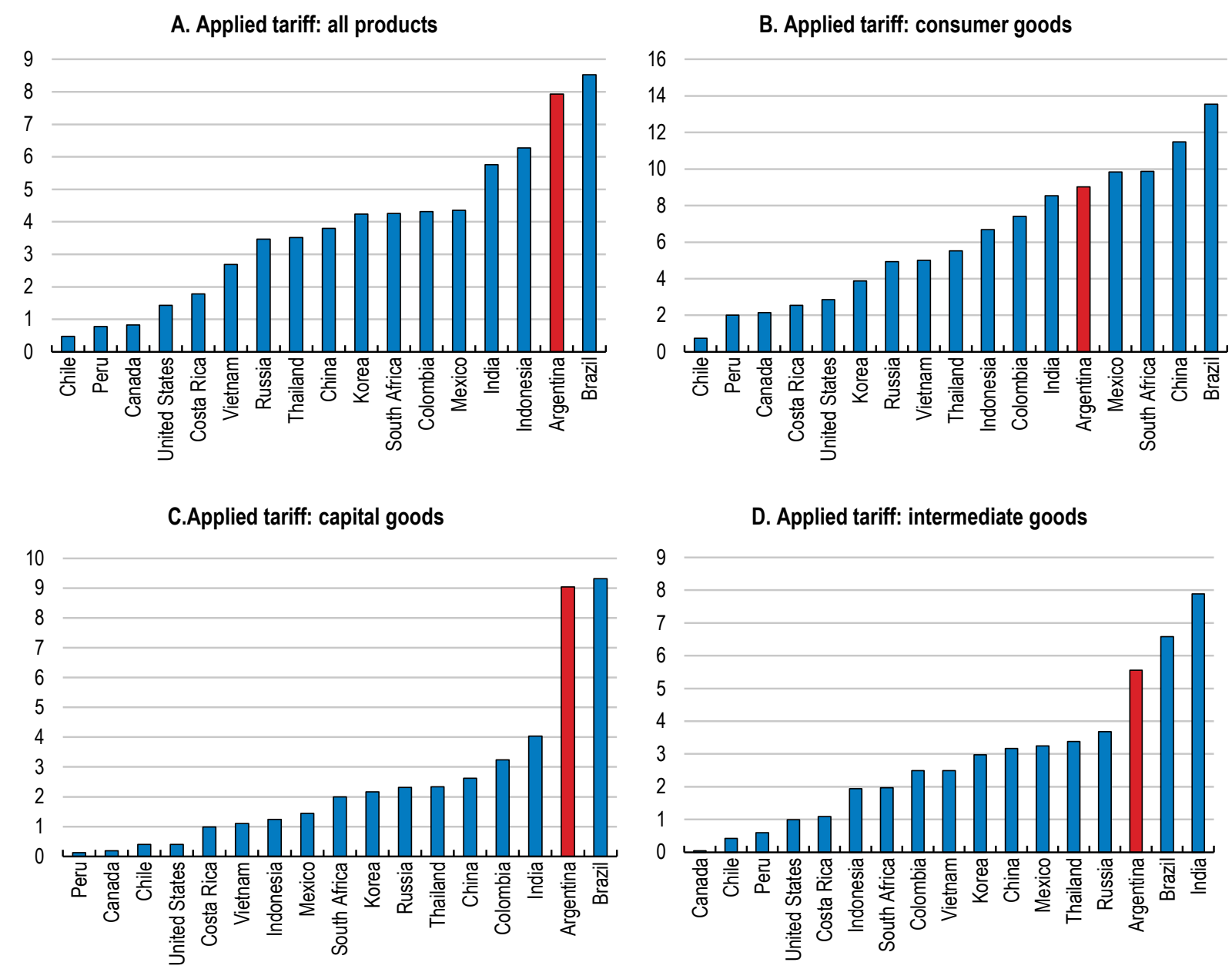

Note: Average applied tariffs for each product class are computed as weighted average of effectively applied tariffs (AHS) across single products within the product class, whereby the tariffs are weighted by the import value of each product.

Source: World Integrated Trade Solution database (WITS).

StatLink 제내 http://dx.doi.org/10.1787/888933942885

Behind high average tariffs lies a strong heterogeneity in tariff rates across different industries (Figure 9). Wearing apparel, textile products and footwear, motor vehicles and furniture are highly protected by average tariffs larger than $20 \%$. Also sectors that produce mainly intermediate and capital goods are protected by tariffs of around 15\%, e.g. fabricated metal products, rubber and plastic products or machinery and equipment. Although tariffs on computers, tablets and notebooks were eliminated in 2017, the average tariff for other office, accounting and computing machinery is still around 11\%. By contrast, tariffs for petroleum, gas, mineral products and other raw materials are low, consistent with being a net importer of oil and gas. 
Figure 9. Many industries are protected through high import tariffs

Average tariffs by industry for the year 2018 (in \%)

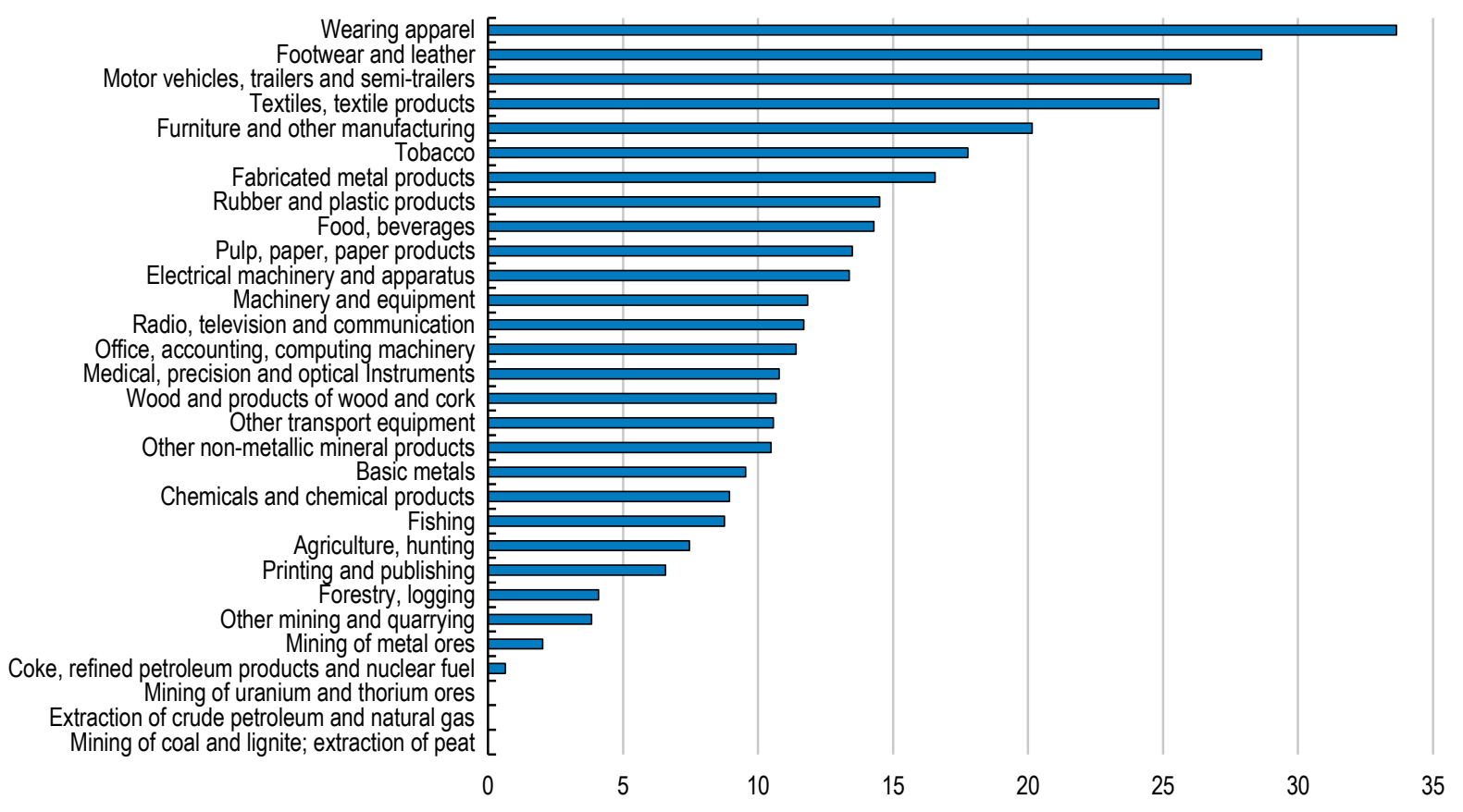

Source: Ministry of Production and Employment (June 2018).

StatLink जils https://doi.org/10.1787/888933943075

\section{Non-tariff barriers add substantially to levels of protection}

Beyond tariffs, non-tariff measures also add to import costs in Argentina. Non-automatic import licenses have effectively also added to protection from foreign competition in certain industries (Figure 10). In sectors like textiles and wearing apparel, footwear, leather products and furniture, more than $70 \%$ of imports are still subject to non-automatic import licenses. More than $30 \%$ of all imports of machinery and electronic equipment, optical and medical instruments as well as toys, instruments and games are still subject to nonautomatic import licenses.

While countries around the world increasingly use non-tariff measures to protect domestic industries, it is important to acknowledge that many non-tariff measures result from legitimate policy objectives and are not necessarily motivated by protectionist motives (Baldwin and Evenett, 2009 $[8]$; WTO, 2012 $[9]$; Bown and Crowley, 2013 ${ }_{[10]}$ ). For example, product standards and technical regulations are mainly imposed to overcome market failures and protect the health of domestic consumers.

Recent evidence shows that countries can use product standards and their enforcement to protect domestic industries (Grundke and Moser, 2019 [11] $)$. Non-tariff measures such as requirements to obtain a non-automatic import license can impose considerable costs on importers. Argentina has made considerable progress in reducing the number of items subject to non-automatic import licenses. 
Figure 10. Non-automatic import licenses are required in many industries

Share of imports requiring a non-automatic import license in 2018 (in \% of total industry imports)

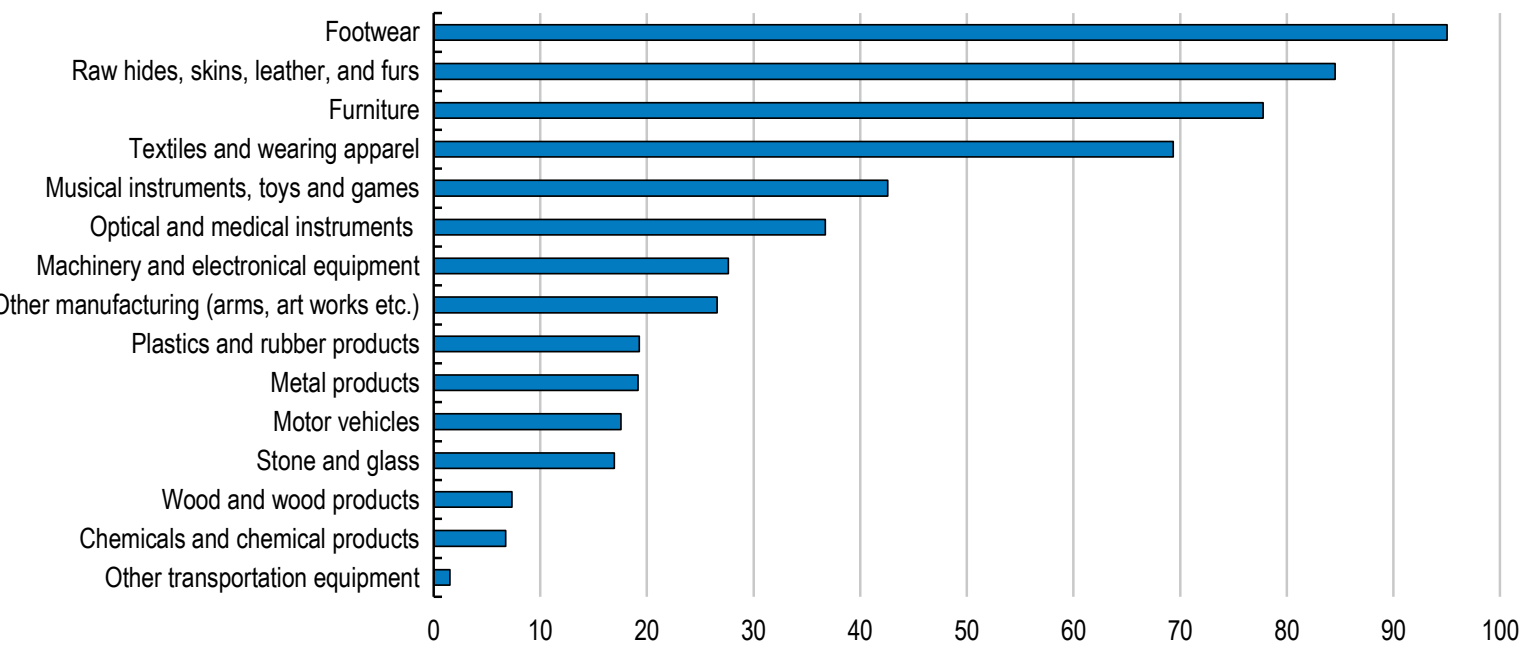

Note: The raw data indicates which HS 8 digit code is covered by the requirements of non-automatic import licenses in Argentina as of June 2018. The graph shows for each group of HS 2 digit product groups the share of import value that is covered by non-automatic import licenses.

Source: Ministry of Production and Employment (June 2018).

\section{StatLink त्माज् https://doi.org/10.1787/888933943094}

\section{Figure 11. Domestic producers play a dominant role in many tradable sectors}

Share of domestic production in total final demand by industry (in \%)

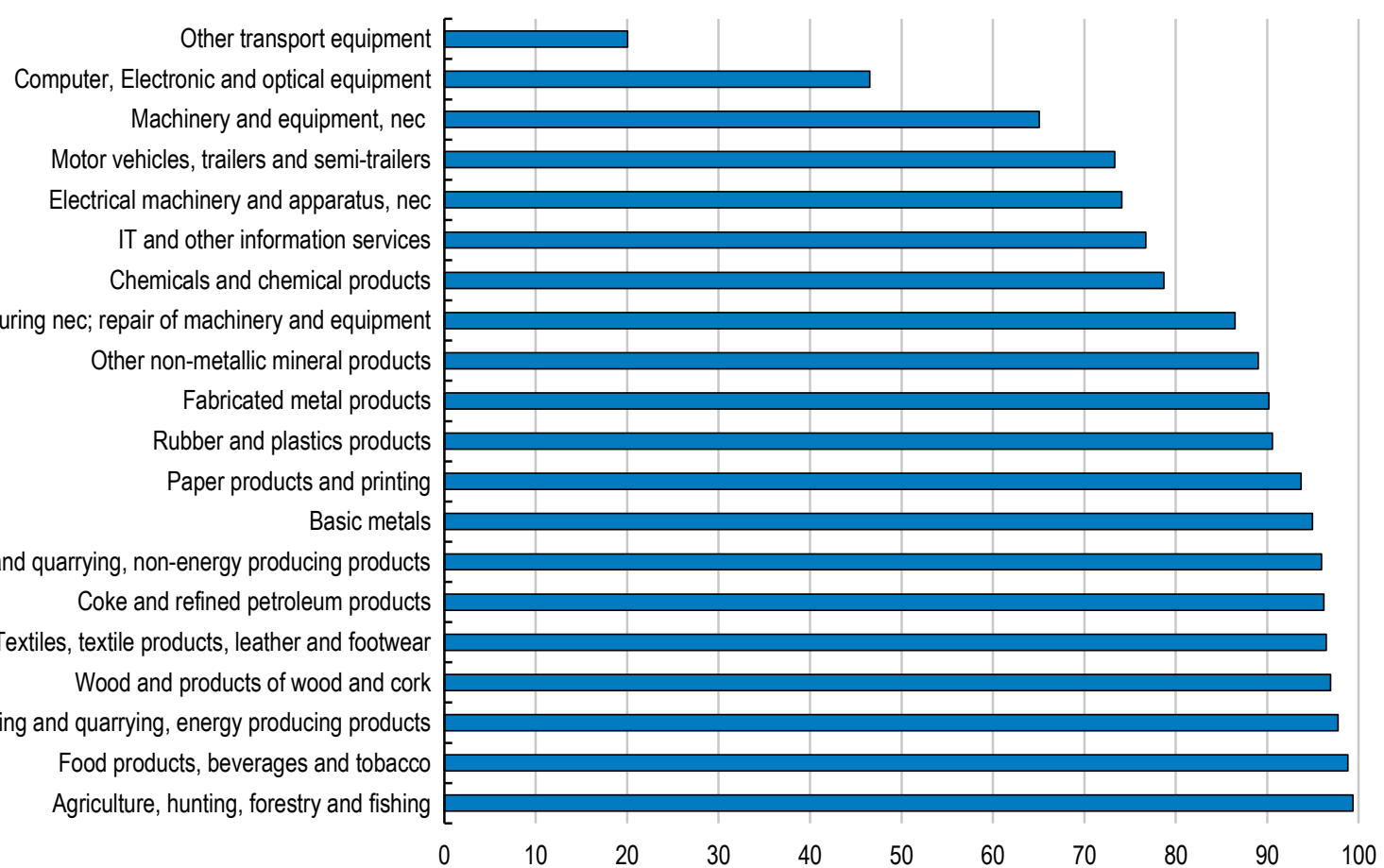

Source: OECD Trade in Value Added (TiVA) data base (September 2018).

StatLink तiाs https://doi.org/10.1787/888933943113 


\section{Many markets are dominated by domestic producers and prices are high}

As a result of the effect of tariff and non-tariff barriers, key tradable sectors are dominated by domestic producers (Figure 11). Bearing in mind that Argentina's population is only 45 million, the high share of total final demand served by domestic producers, in many sectors over $90 \%$, is surprising. By comparison, only $75 \%, 74 \%$ and $80 \%$ of tradable goods are domestically produced in Chile, Mexico and Colombia, respectively.

This is one factor behind the significantly higher prices that Argentinian consumers pay for a wide range of goods from protected sectors. A case in point is clothing, where trade protection is very high (Figure 12). High prices are consistent with evidence of rents that have resulted from shielding domestic producers from foreign competition. This has also reduced the incentives and discipline for undertaking constant improvements and innovation (Martínez Licetti et al., 2018 [12]).

\section{Figure 12. Prices are high in international comparison}

Prices for clothing in current USD (June 2019)

\section{Clothing}

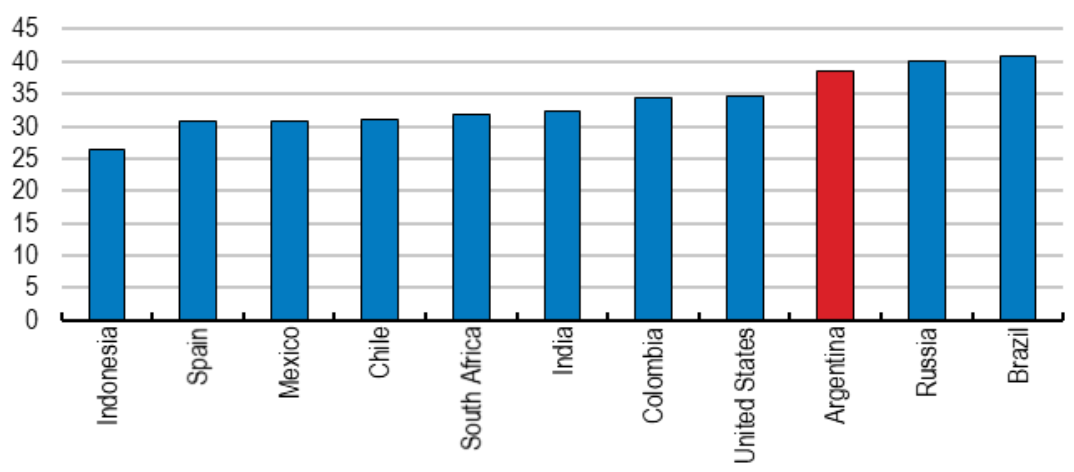

Note: Clothing prices are proxied by the price of a dress in a Chain Store. Due to the real devaluation during the course of the year 2018, the USD prices of Argentinian products have decreased in comparison to other countries rendering Argentinian products more competitive in global markets (Figure 24). However, relative price differences for many goods and services persist across countries, when they are expressed in relationship to a common consumption basket (in USD PPP).

Source: OECD computations based on Numbeo data.

StatLink जiाs https://doi.org/10.1787/888933943132

\section{Lowering trade barriers can create jobs and boost growth}

Lowering trade barriers can bring substantial benefits through a number of channels. Consumers can expect lower prices, higher quality and more variety. For domestic producers, the situation is slightly more complex as they are affected in several ways on input and output markets, but the newly created opportunities clearly outweigh the associated challenges.

\section{Trade can reduce consumer prices, benefitting particularly poorer households}

The most evident and immediate effects of lower trade barriers would be lower prices for consumers (Amiti, Redding and Weinstein, 2019 ${ }_{[13]}$ ). To quantify the effects of lower trade 
barriers on household welfare for different segments of the income distribution, this paper uses data from the Argentinian household survey "Encuesta Nacional de Gastos de los Hogares (ENGHO)" from the year 2012 and 2013. The analysis simulates the partial equilibrium effects of a 100\% (50\%) cut in tariffs and non-tariff measures (NTMs) on household purchasing power, taking into account differences in the consumption basket across households (see Annex A.1). The estimates suggest average gains of $25 \%$ under the ambitious scenario of a full removal of trade barriers (Figure 13).

Figure 13. Potential consumer benefits from lower trade barriers are progressive

Increases in real purchasing power (relative to total expenditures) due to a reduction of tariffs and/or nontariff measures (NTMs) by 100\% for each household income decile (in \%)
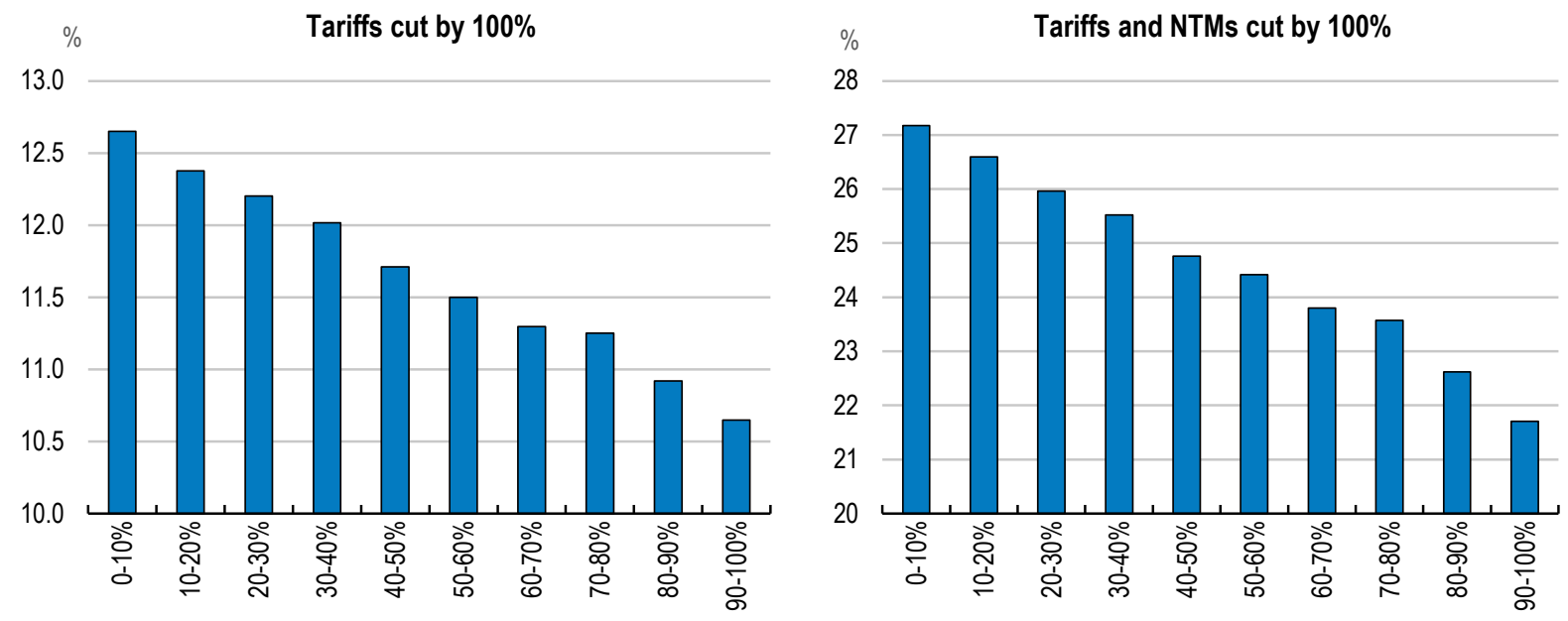

Note: The horizontal axis shows the ten income deciles of the household income distribution, starting with the poorest decile (0-10\%). Ad-valorem equivalents of non-tariff measures (NTMs) for Argentina are taken from (Cadot, Gourdon and van Tongeren, 2018 ${ }_{[14]}$ ). Tariff rates at the detailed product level are taken from WITS and from data sent by the Ministry of Production and Employment. The data and the methodology are described in more detail in Annex A.1.

Source: OECD calculations based on the Argentinian household survey ENGH 2012/2013.

StatLink तiाs ht htps://doi.org/10.1787/888933943151

Moreover, these benefits are progressive as lower income households spend larger shares of their incomes on tradable goods such as food, home appliances, furniture and clothing. The lowest-income decile could gain as much as $27 \%$ in terms of additional purchasing power, compared to $22 \%$ for the top decile. Lower tariffs and non-tariff measures would therefore bring particular benefits to poor consumers, which is in line with evidence found for other countries (Fajgelbaum and Khandelwal, 2016 $[15]$; Porto, 2006 $[16])$.

Besides price reductions, a stronger integration would give consumers access to a larger variety and higher quality of products and services (Broda and Weinstein, 2006 $6_{[17]}$ ). Nontariff measures seem to play a particularly important role in the import protection for basic consumption goods and reducing only tariffs would have about half the effect of full liberalisation. Non-tariff measures also include legitimate technical regulations or product standards, so that a realistic reduction of trade barriers might not include a full elimination of non-tariff measures (WTO, 2012 $2_{[9]}$ ). Reducing tariff and non-tariff barriers by $50 \%$ still leads to an average increase of the real purchasing power of around $12.5 \%$ with poorer households benefitting relatively more than richer ones (Annex Figure A.1). Moreover 
trade costs related to regulatory differences across countries could be further reduced by international harmonization of technical regulations and product standards.

In the specific case of passenger vehicles, the falling prices that are likely to result from a reduction of trade protection might also bring environmental benefits if they encourage a shift towards newer cars. As nearly $50 \%$ of vehicles are older than 10 years and $22 \%$ older than 20 years, a fleet renovation has significant potential to reduce emission levels (World Bank, 2016 $[18])$. The use of old vehicles without modern pollution filters is one factor behind high PM2.5 pollution levels of six times the WHO recommended threshold of 10 $\mu \mathrm{g} / \mathrm{m} 3$ in Buenos Aires, three times in Córdoba and twice in Mendoza.

\section{For producers, trade improves access to intermediate inputs and capital goods}

With respect to companies and employment, the effects of lowering trade barriers generally combine medium-term benefits with short-term adjustment costs. Just like consumers, firms gain improved access to intermediate inputs and capital goods. Simultaneously, they also face fiercer competition on their output markets, an issue that will be discussed in the next section.

When firms are constrained in their choice of using imported inputs, they are likely to pay higher prices and may even have to source lower quality inputs. The same applies to capital goods used in the production process. Lower trade barriers will bring down prices and raise the quality of these inputs. This may be the result of rising imports, but also of the reaction of domestic producers to rising competition. Many domestic producers of intermediate goods would react to the stronger foreign competition by upgrading their production processes and improving their products, and only the least productive ones would lose market share (Amiti and Khandelwal, 2013 ${ }_{[19]}$; Topalova and Khandelwal, 2011 $1_{[20]}$; Pavcnik, 2002 $[21])$. Hence increased import competition will not necessarily imply a strong substitution of domestic intermediate inputs and capital goods by imports.

Improved sourcing options for intermediate inputs and capital goods lowers production costs and may allow domestic firms to upgrade their production processes through technology embedded in new machinery (Amiti and Konings, 2007 ${ }_{[1]}$ ). Moreover, there is evidence that increased importing activities of firms can help building foreign networks and acquiring knowledge about foreign markets, which is crucial for increasing export activities (He and Dai, 2017 [22]; Blalock and Veloso, 2007[23]).

Due to high tariffs and non-tariff measures on intermediate inputs, Argentinian firms import - on average- a much lower share of their intermediate inputs than producers in other countries (Figure 14). Looking across firms, evidence for Argentina suggests strong links between the use of imported inputs, productivity and export propensity (Brambilla, Depetris Chauvin and Porto, 2017[24]; Bas, 2012 $2_{[25]}$ ). Firm-level analysis conducted for this report also finds a significant positive relationship between the use of imported intermediate inputs and total factor productivity of Argentinian firms (see Annex A.2). Moreover, firms that use technology licensed by a foreign company have a $2.3 \%$ higher total factor productivity, emphasising the importance of reducing import barriers for facilitating technology diffusion. 
Figure 14. Firms use few imported intermediate inputs

Share of imported intermediate inputs over total inputs (in \%)

70

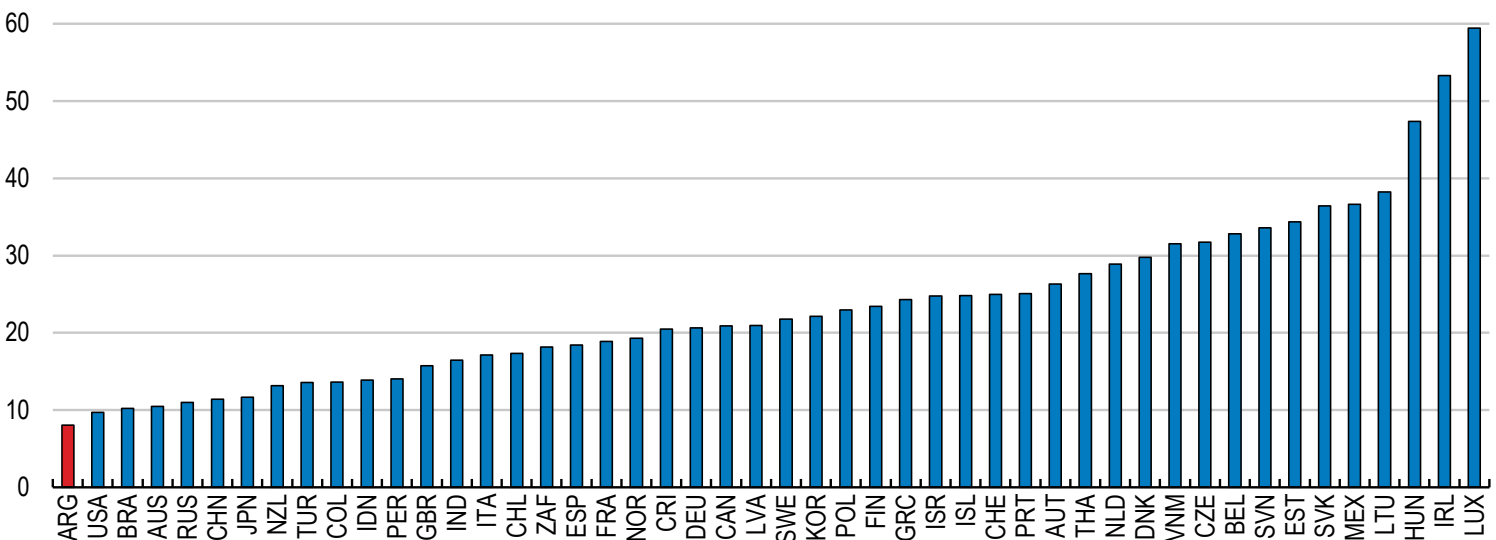

Source: OECD Trade in Value Added (TiVA) data base (September 2018).

StatLink त्गाज् https://doi.org/10.1787/888933943170

To investigate how sectoral economic activity and exports have reacted to changes in input tariffs, this paper uses a balanced industry panel dataset from 1996 until 2016, which provides information on sectoral input tariffs, employment, average wages, production and value added as well as several indicators for the integration into global value chains. Fixed effect estimations suggest that whenever a sector experienced an increase in input prices due to higher input tariffs, this came along with lower employment, production and value added as well as with a strong decline in exports (Table 2; for the empirical methodology see Annex A.3).

Table 2. Effects of average input tariffs on economic activity (within economic sectors)

OLS regressions control for sector fixed effects and use only variation within economic sectors

\begin{tabular}{|c|c|c|c|c|c|c|c|c|}
\hline & $(1)$ & $(2)$ & (3) & (4) & $(5)$ & $(6)$ & (7) & $(8)$ \\
\hline $\begin{array}{l}\text { Dependent } \\
\text { Variables: }\end{array}$ & $\begin{array}{l}\text { Log of } \\
\text { employment }\end{array}$ & $\begin{array}{l}\text { Log of } \\
\text { production }\end{array}$ & $\begin{array}{l}\text { Log of } \\
\text { value } \\
\text { added }\end{array}$ & $\begin{array}{l}\text { Log of } \\
\text { output per } \\
\text { worker }\end{array}$ & $\begin{array}{l}\text { Log of value } \\
\text { added per } \\
\text { worker }\end{array}$ & $\begin{array}{l}\log \text { of } \\
\text { exports }\end{array}$ & $\begin{array}{c}\text { Log of value } \\
\text { added } \\
\text { exports }\end{array}$ & $\begin{array}{l}\text { Log of real } \\
\text { wages }\end{array}$ \\
\hline \multirow{2}{*}{$\begin{array}{l}\text { Average tariffs } \\
\text { for Inputs }\end{array}$} & $-0.023^{* * *}$ & $-0.018^{* *}$ & $-0.024^{\star *}$ & 0.003 & -0.004 & $-0.062^{* *}$ & $-0.064^{* *}$ & $0.007^{*}$ \\
\hline & $(0.007)$ & $(0.009)$ & $(0.011)$ & $(0.011)$ & $(0.012)$ & $(0.029)$ & $(0.028)$ & $(0.004)$ \\
\hline Sector FE & Yes & Yes & Yes & Yes & Yes & Yes & Yes & Yes \\
\hline Year FE & Yes & Yes & Yes & Yes & Yes & Yes & Yes & Yes \\
\hline Observations & 672 & 561 & 561 & 512 & 512 & 548 & 555 & 672 \\
\hline R-squared & 0.986 & 0.980 & 0.979 & 0.936 & 0.906 & 0.962 & 0.970 & 0.996 \\
\hline $\begin{array}{l}\text { Adjusted R- } \\
\text { squared }\end{array}$ & 0.985 & 0.978 & 0.976 & 0.930 & 0.896 & 0.958 & 0.967 & 0.996 \\
\hline
\end{tabular}

Note: For each dependent variable, the table shows the results of fixed effects regressions that control for unobservable sector and time specific characteristics and only use variation within economic sectors over time for identification. Due to data availability issues, the sample sizes vary according to the respective dependent variables. Regressions using the same set of observations show similar results and can be obtained upon request. Robust standard errors in parenthesis, *** $\mathrm{p}<0.01$, ** $\mathrm{p}<0.05$, * $\mathrm{p}<0.1$.

Source: OECD calculations based on data from OECD TiVA and INDEC. 
Using these estimated relationships for simulation analysis suggests that a reduction of input tariffs by $50 \%$ is associated with an average $7 \%$ increase in sectoral employment, whereas production and value added increase by $5 \%$ and $7 \%$, respectively (Figure 15). Furthermore, the increased access to cheaper and higher quality foreign inputs is associated with an even larger increase of gross exports as well as exports in value added terms by $18 \%$ and $19 \%$, respectively. These results are in line with existing firm level evidence for Argentina (Bas, 2012 ${ }_{[25]}$ ). Output or value added per worker, however, is not affected much, as sectoral employment increases about the same amount as production or value added.

Figure 15. Reducing input tariffs boosts economic activity and exports Increase of economic activity and exports (in \%) when average input tariffs are cut by $50 \%$

25

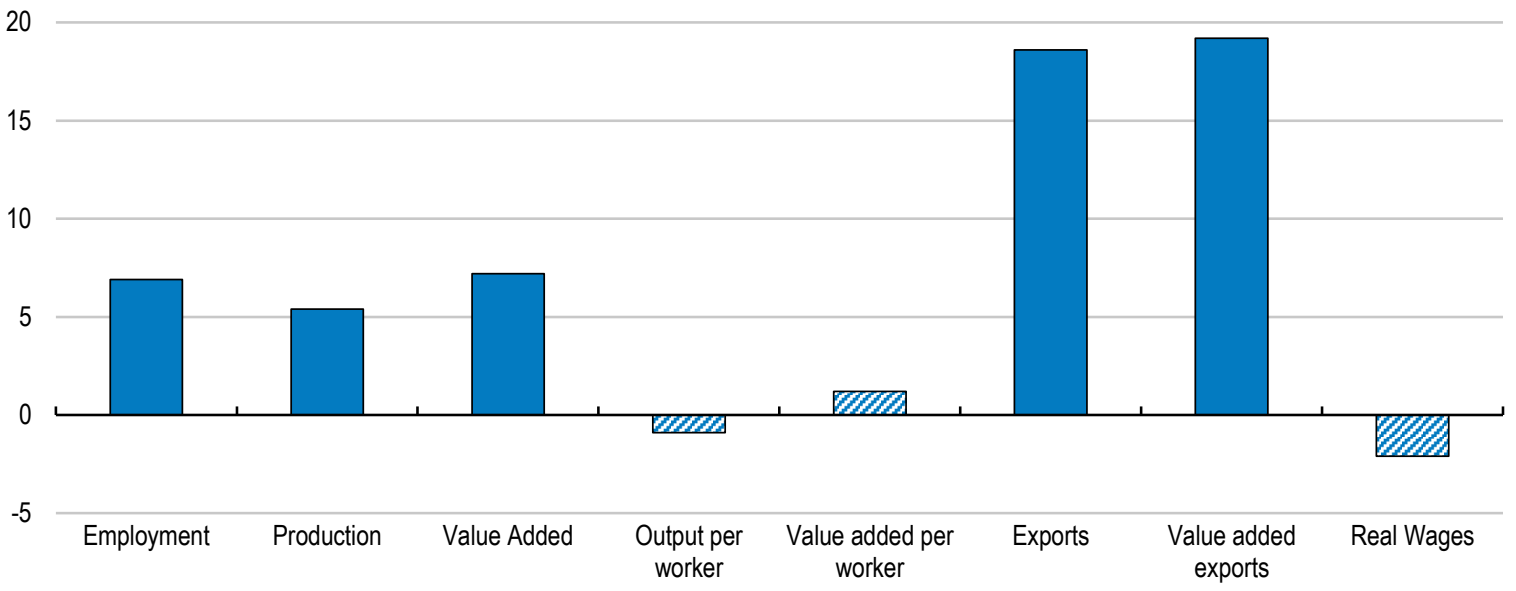

Note: The simulations are based on a partial equilibrium exercise whereby the $50 \%$ input tariff cut is simulated at the sample average of input tariffs for the latest available year in the sample (2016). Shaded bars indicate that the coefficient that underlies the simulations is not significant at the 5\% level.

Source: OECD calculations based on OECD TiVA.

StatLink त्गाडs https://doi.org/10.1787/888933943189

These results draw only on variation within industries over time, which allows controlling for time-constant sector-specific differences that might otherwise bias the results. At the same time, this excludes a large part of the available variation in the data, notably across economic sectors. Additional analysis using tariff variation across industries supports the baseline results and finds that industries facing higher average input tariffs have lower labour productivity, export significantly less and pay lower wages (Table 3). This is in line with earlier work using firm level data, which finds that Argentinian exporters are around $40 \%$ more productive and pay $31 \%$ higher wages than non-exporters (Brambilla, Depetris Chauvin and Porto, 2017 $[24]$ ). 
Table 3. Effects of average input tariffs on economic activity (across economic sectors)

OLS regressions do not control for fixed effects and use variation across economic sectors

\begin{tabular}{lcccccccc}
\hline & $(1)$ & $(2)$ & $(3)$ & $(4)$ & $(5)$ & $(6)$ & $(7)$ & $(8)$ \\
\hline \multicolumn{1}{c}{$\begin{array}{c}\text { Dependent } \\
\text { Variables: }\end{array}$} & $\begin{array}{c}\text { Log of } \\
\text { employment }\end{array}$ & $\begin{array}{c}\text { Log of } \\
\text { production }\end{array}$ & $\begin{array}{c}\text { Log of } \\
\text { value } \\
\text { added }\end{array}$ & $\begin{array}{c}\text { Log of output } \\
\text { per worker }\end{array}$ & $\begin{array}{c}\text { Log of value } \\
\text { added per } \\
\text { worker }\end{array}$ & $\begin{array}{c}\text { Log of } \\
\text { exports }\end{array}$ & $\begin{array}{c}\text { Log of value } \\
\text { added } \\
\text { exports }\end{array}$ & $\begin{array}{c}\text { Log of real } \\
\text { wages }\end{array}$ \\
Average tariffs & 0.004 & $-0.134^{* * *}$ & $-0.115^{* * *}$ & $-0.141^{* * *}$ & $-0.123^{* * *}$ & $-0.127^{* * *}$ & $-0.139^{* * *}$ & $-0.067^{* * *}$ \\
for Inputs & $(0.020)$ & $(0.014)$ & $(0.018)$ & $(0.014)$ & $(0.010)$ & $(0.031)$ & $(0.031)$ & $(0.008)$ \\
Sector FE & No & No & No & No & No & No & No & No \\
Year FE & Yes & Yes & Yes & Yes & Yes & Yes & Yes & Yes \\
Observations & 672 & 561 & 561 & 512 & 512 & 548 & 555 & 672 \\
R-squared & 0.030 & 0.191 & 0.141 & 0.336 & 0.366 & 0.046 & 0.043 & 0.869 \\
Adjusted R- & -0.00174 & 0.165 & 0.114 & 0.315 & 0.345 & 0.0151 & 0.0129 & 0.865 \\
squared & & & & & & & & \\
\hline
\end{tabular}

Note: For each dependent variable, the table shows the results of OLS regressions that control for unobservable time specific characteristics and use variation across economic sectors for identification. Due to data availability issues, the sample sizes vary according to the respective dependent variables. Regressions using the same set of observations show similar results and can be obtained upon request. Robust standard errors in parenthesis, $* * * \mathrm{p}<0.01, * * \mathrm{p}<0.05, * \mathrm{p}<0.1$.

Source: OECD calculations based on data from OECD TiVA and INDEC.

The link between lower input tariffs and higher output and exports is significant across economic sectors, but tends to be higher in those sectors that make more use of imported inputs (Figure 16). For example, motor vehicles, electrical machinery as well as computer, electronic and optical equipment use more imported intermediate inputs and stand to gain more from a reduction in input tariffs than other sectors. 
Figure 16. The use of imported inputs varies across sectors

Share of imported intermediate inputs in total sectoral production (in \%)

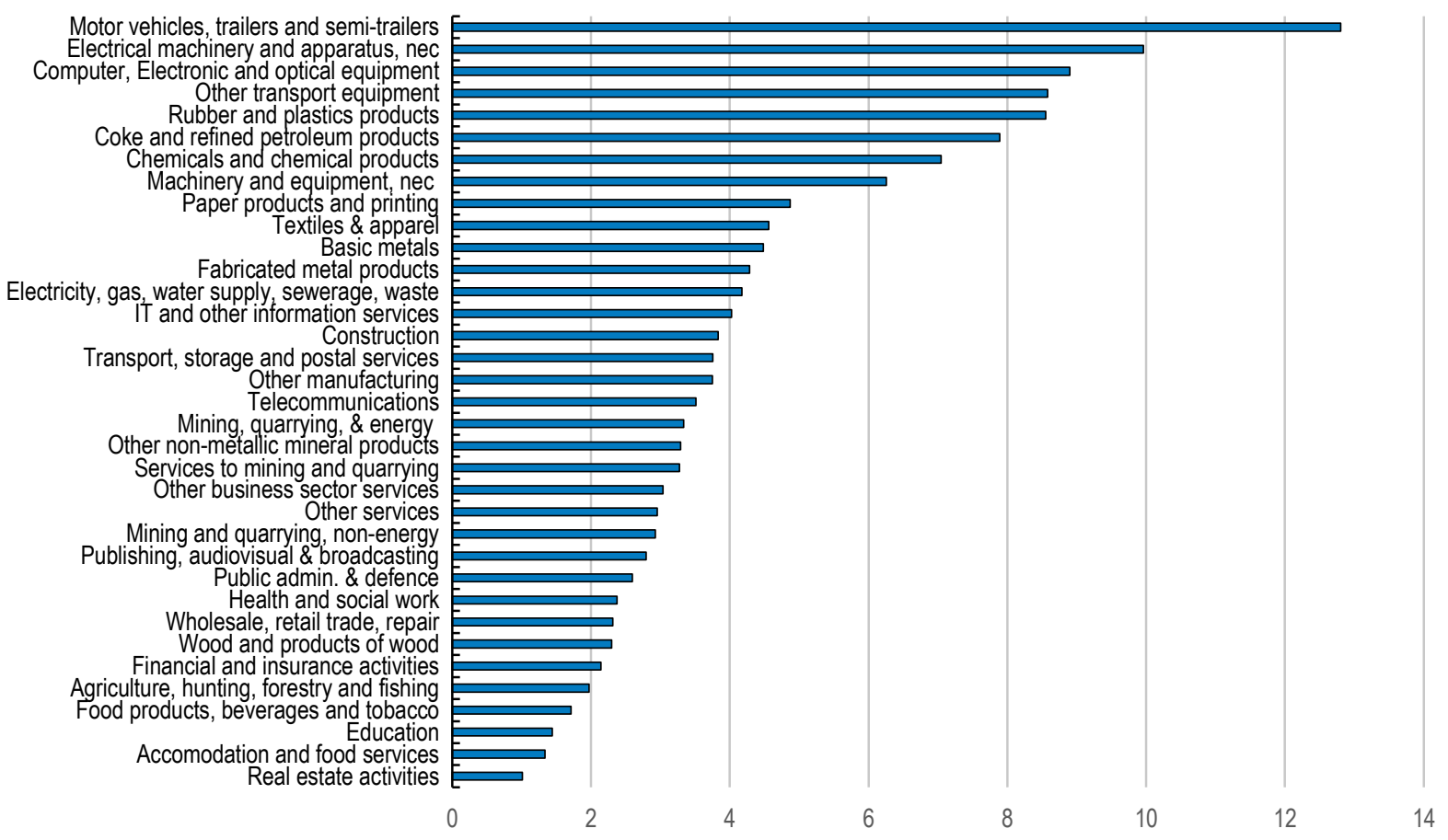

Source: OECD Trade in Value Added (TiVA) data base (September 2018).

StatLink जiाs https://doi.org/10.1787/888933943208

\section{Trade can stimulate competition and raise productivity}

Besides the productivity enhancing effects through the input side, the disciplining effect of import competition in the same sector would force companies to reduce inefficiencies, upgrade their production processes through more advanced technologies, increase product quality and reduce high prices that result from low domestic competition (Amiti and Khandelwal, 2013 ${ }_{[19]}$; De Loecker et al., 2016 $[26]$ ). This could lead to substantial gains in productivity, and it does not necessarily imply a massive substitution towards imports. It rather leads to a revitalising effect on the more productive domestic firms, while some lowproductivity firms would leave the market, freeing resources for the more productive ones to grow (Melitz, 2003 [27]; Pavcnik, 2002 [21]).

Just as some firms lose domestic market share in the face of stronger integration and may eventually leave the market, others seize newly arising export opportunities, expand and hire new workers. It is precisely this reallocation process that will allow capital and labour to flow to more productive sectors or firms where new and better-paying jobs can be created (Brandt, Van Biesebroeck and Zhang, 2012 ${ }_{[28]}$; Criscuolo, Gal and Menon, 2014 ${ }_{[29]}$; Criscuolo and Timmis, 2018 $\left.{ }_{[30]}\right)$. A significant share of productivity growth in advanced economies can be attributed to these reallocation effects (Hsieh and Klenow, 2009 [31] $)$. For Argentina, estimates suggest potential productivity gains on the order of 50-60\% (Busso, Madrigal and Pagés, 2013 [32]). 
To investigate how sectoral economic activity, productivity and exports have reacted to changes in output tariffs, this paper uses the same sectoral panel dataset for Argentina from 1995 until 2016 described in the preceding section, adding average output tariffs at the sector level for Argentina from OECD tariff data. Fixed-effect estimations suggest that whenever a sector experienced an increase in output tariff protection, this came along with lower labour productivity, production and value added as well as slightly higher employment (Table 4, for methodological details see Annex A.3). For sectoral exports or average wages, no significant link with trade protection could be detected.

Table 4. Effects of output tariffs on economic activity (within economic sectors)

OLS regressions control for sector fixed effects and use only variation within economic sectors

\begin{tabular}{|c|c|c|c|c|c|c|c|c|}
\hline & (1) & (2) & (3) & (4) & (5) & (6) & (7) & (8) \\
\hline $\begin{array}{l}\text { Dependent } \\
\text { Variables: }\end{array}$ & $\begin{array}{l}\text { Log of } \\
\text { employment }\end{array}$ & $\begin{array}{l}\text { Log of } \\
\text { production }\end{array}$ & $\begin{array}{l}\text { Log of } \\
\text { value } \\
\text { added }\end{array}$ & $\begin{array}{l}\text { Log of output } \\
\text { per worker }\end{array}$ & $\begin{array}{l}\text { Log of value } \\
\text { added per } \\
\text { worker }\end{array}$ & $\begin{array}{l}\text { Log of } \\
\text { exports }\end{array}$ & $\begin{array}{c}\text { Log of value } \\
\text { added } \\
\text { exports }\end{array}$ & $\begin{array}{l}\text { Log of real } \\
\text { wages }\end{array}$ \\
\hline \multirow{2}{*}{$\begin{array}{l}\text { Average output } \\
\text { tariffs }\end{array}$} & $0.007^{* * *}$ & $-0.018^{* * *}$ & $-0.018^{\star * *}$ & $-0.026^{\star * *}$ & $-0.026^{\star * *}$ & -0.005 & -0.005 & 0.002 \\
\hline & $(0.003)$ & $(0.005)$ & $(0.006)$ & $(0.006)$ & $(0.006)$ & $(0.012)$ & $(0.011)$ & $(0.001)$ \\
\hline Sector FE & Yes & Yes & Yes & Yes & Yes & Yes & Yes & Yes \\
\hline Year FE & Yes & Yes & Yes & Yes & Yes & Yes & Yes & Yes \\
\hline Observations & 378 & 306 & 306 & 288 & 288 & 306 & 306 & 378 \\
\hline R-squared & 0.991 & 0.994 & 0.988 & 0.981 & 0.965 & 0.950 & 0.951 & 0.997 \\
\hline $\begin{array}{l}\text { Adjusted R- } \\
\text { squared }\end{array}$ & 0.990 & 0.993 & 0.987 & 0.979 & 0.960 & 0.943 & 0.945 & 0.997 \\
\hline
\end{tabular}

Note: For each dependent variable, the table shows the results of fixed-effects regressions that control for unobservable sector- and time-specific characteristics and only use variation within economic sectors over time for identification. Due to data availability issues, the sample sizes vary according to the respective dependent variables. Regressions using the same set of observations show similar results and can be obtained upon request. Robust standard errors in parenthesis, $* * * \mathrm{p}<0.01,{ }^{* *} \mathrm{p}<0.05, * \mathrm{p}<0.1$.

Source: OECD calculations based on data from OECD TiVA and INDEC.

Simulations based on these estimations suggest that on average, a reduction of output tariffs by $50 \%$ would be associated with a $10 \%$ increase in sectoral labour productivity (Figure 17). This productivity increase translates into 7\% higher output and value added. Unless the demand curve has changed, this would suggest that prices have dropped or quality has improved. In a few industries like textiles, wearing apparel, footwear and other transport equipment, employment contracts as trade protection lessens. Although all other industries slightly increase sectoral employment in reaction to lower import protection, the above mentioned sectors explain a small average employment decrease of around 3\%.

These results draw only on variation within economic sectors across time for identification. This allows controlling for time constant sector-specific differences that otherwise might bias the results, but disregards a large part of the available variation in the data, notably across economic sectors. Estimations without fixed effects confirm the baseline results and show that sectors with higher import protection have significantly lower labour productivity, value added and output, but slightly higher employment (Table 5). The positive employment effects of protection vanish once again when abstracting from two sectors (textiles, wearing apparel, footwear and other transport equipment). Moreover, the results show that the more protected sectors export significantly less and pay lower wages. Additional robustness checks using an instrumental variable approach support the baseline results (see Annex A.3). 
Figure 17. Decreasing output tariffs boosts productivity, but can reduce employment in a few sectors

Average increase of economic activity and exports (in \%) when output tariffs are cut by $50 \%$

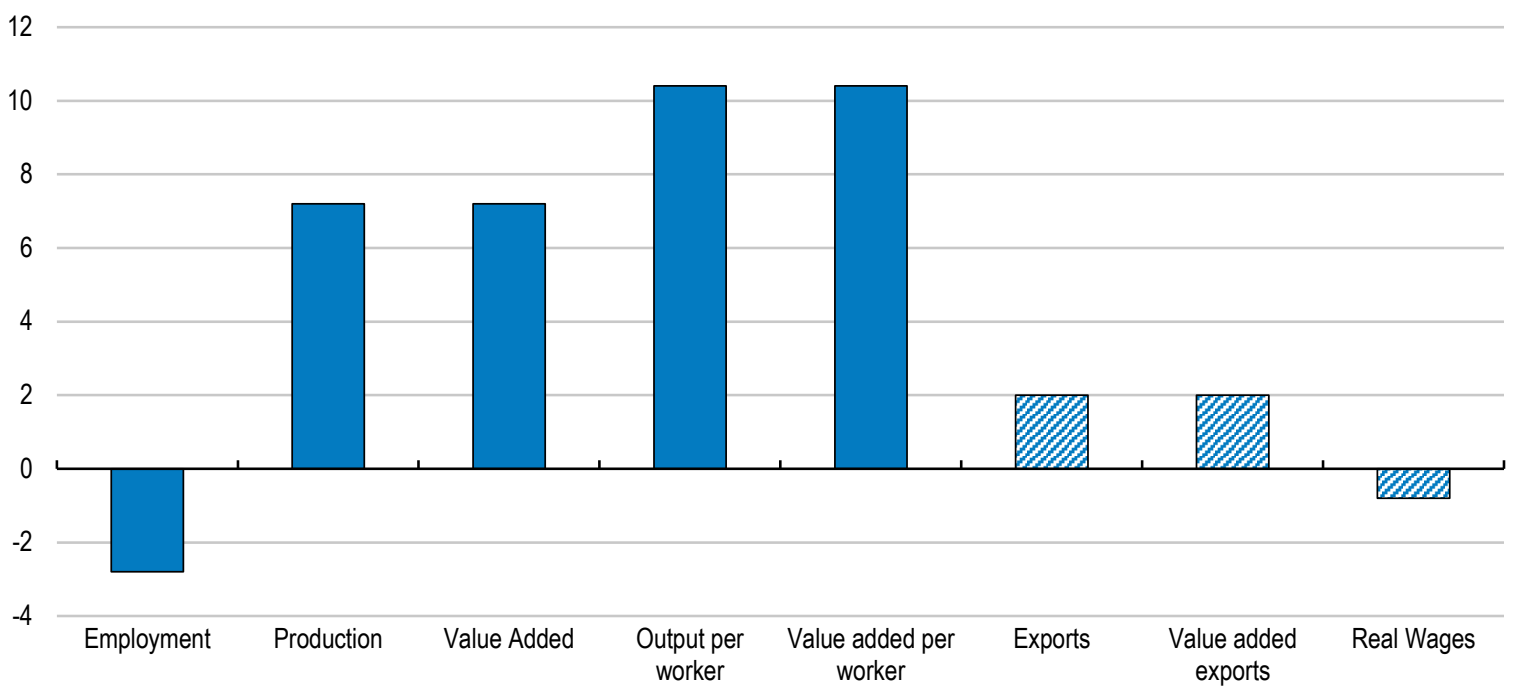

Note: The simulations are based on a partial equilibrium exercise whereby the $50 \%$ output tariff cut is simulated at the sample average of output tariffs for the latest available year in the sample (2016). Shaded bars indicate that the coefficient that underlies the simulations is not significant at the 5\% level.

Source: OECD calculations based on OECD TiVA and tariff data from WITS.

StatLink त्गा5 https://doi.org/10.1787/888933943227

Table 5. Effects of output tariffs on economic activity (across economic sectors)

OLS regressions do not control for fixed effects and use variation across economic sectors

\begin{tabular}{|c|c|c|c|c|c|c|c|c|}
\hline & (1) & (2) & (3) & (4) & (5) & (6) & (7) & (8) \\
\hline $\begin{array}{l}\text { Dependent } \\
\text { Variables: }\end{array}$ & $\begin{array}{l}\text { Log of } \\
\text { employment }\end{array}$ & $\begin{array}{l}\text { Log of } \\
\text { production }\end{array}$ & $\begin{array}{l}\text { Log of } \\
\text { value } \\
\text { added }\end{array}$ & $\begin{array}{l}\text { Log of output } \\
\text { per worker }\end{array}$ & $\begin{array}{l}\text { Log of value } \\
\text { added per } \\
\text { worker }\end{array}$ & $\begin{array}{l}\log \text { of } \\
\text { exports }\end{array}$ & $\begin{array}{l}\text { Log of value } \\
\text { added } \\
\text { exports }\end{array}$ & $\begin{array}{l}\text { Log of real } \\
\text { wages }\end{array}$ \\
\hline \multirow{2}{*}{$\begin{array}{l}\text { Average output } \\
\text { tariffs }\end{array}$} & $0.025^{\star *}$ & $-0.047^{* * *}$ & $-0.046^{\star \star *}$ & $-0.085^{\star * *}$ & $-0.085^{\star \star *}$ & $-0.079^{* \star *}$ & $-0.080^{\star \star \star}$ & $-0.046^{* \star *}$ \\
\hline & $(0.011)$ & $(0.012)$ & $(0.013)$ & $(0.011)$ & $(0.009)$ & $(0.016)$ & $(0.016)$ & $(0.005)$ \\
\hline Sector FE & No & No & No & No & No & No & No & No \\
\hline Year FE & Yes & Yes & Yes & Yes & Yes & Yes & Yes & Yes \\
\hline Observations & 378 & 306 & 306 & 288 & 288 & 306 & 306 & 378 \\
\hline R-squared & 0.053 & 0.113 & 0.119 & 0.299 & 0.395 & 0.148 & 0.136 & 0.876 \\
\hline $\begin{array}{l}\text { Adjusted R- } \\
\text { squared }\end{array}$ & 0.003 & 0.061 & 0.067 & 0.257 & 0.359 & 0.098 & 0.085 & 0.868 \\
\hline
\end{tabular}

Note: For each dependent variable, the table shows the results of OLS regressions that control for unobservable time specific characteristics and use variation across economic sectors for identification. Due to data availability issues, the sample sizes vary according to the respective dependent variables. Regressions using the same set of observations show similar results and can be obtained upon request. Robust standard errors in parenthesis, $* * * \mathrm{p}<0.01, * * \mathrm{p}<0.05, * \mathrm{p}<0.1$.

Source: OECD calculations based on data from OECD TiVA and INDEC. 


\section{Trade can increase productivity through the efficient reallocation of ressources across firms within economic sectors}

To complement the sector-level analysis on the effects of import protection on economic activity presented above, this study uses firm-level panel data for Argentina from the World Bank Enterprise survey to investigate the dispersion of firms' multifactor productivity within different sectors of the economy. The analysis allows a more detailed look on the efficiency of the sectoral allocation of resources across firms and can identify sectors where the misallocation of resources is a major explanation for low average productivity.

The findings are consistent with the international evidence that shielding domestic producers from foreign competition tends to cement existing industry structures and hampers the reallocation of resources towards their most productive uses, both across sectors and across firms within sectors (Annex A.2). First, total factor productivity (TFP) of firms is lower in industries that are protected by higher tariffs (Figure 18).

\section{Figure 18. Productivity is low in sectors with high trade protection}
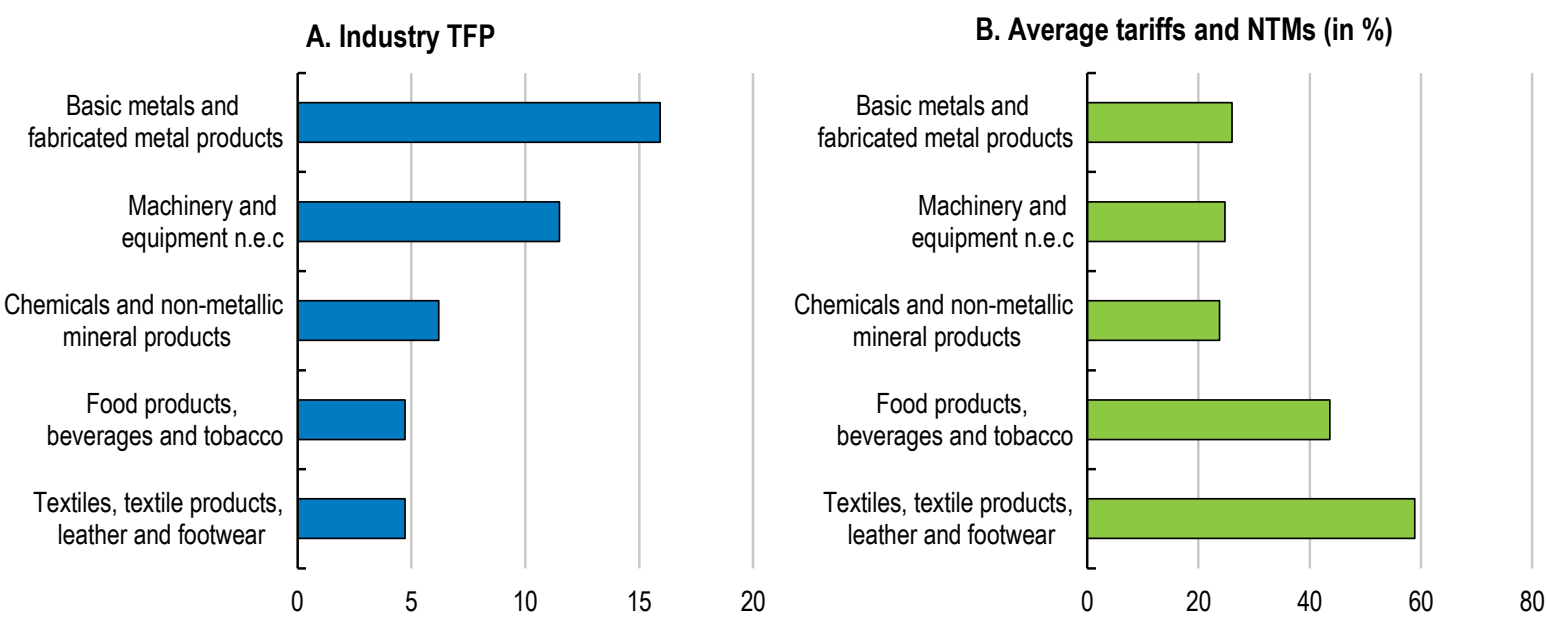

Note: Panel A shows weighted averages of total factor productivity (TFP) within the industry in 2017. Panel B shows the sum of average tariffs and non-tariff measures (NTMs) by industry (in \%).

Source: OECD calculations based on the World Bank Enterprise Survey 2006, 2010 and 2017. Data on tariff is from the Ministry of Production and Employment (June 2018) and data on non-tariff measures from (Cadot, Gourdon and van Tongeren, 2018 $[14])$.

StatLink त्ञाज https://doi.org/10.1787/888933943246

Moreover, sectors with higher trade protection are also characterised by a larger dispersion of total factor productivity across firms (Figure 19). For example, in the textile, leather and footwear industry, where tariffs and NTMs have a combined level of protection of around $60 \%$, many low-productivity firms co-exist with more productive ones and average prices are high (Figure 12). The sector is also characterised by a low allocative efficiency.

A quantitative measure of how much the allocation of resources across firms contributes to aggregate productivity is the decomposition suggested by Olley and Pakes (1996). In this decomposition, the covariance term measures allocative efficiency, or the extent to which firms with greater efficiency have a greater market share. In the textile, leather and footwear industry, the allocation of resources across firms only explains $4 \%$ of average sectoral 
productivity, which is much lower than in metals where it is $24 \%$. This indicates that in the textile, leather and footwear industries resources are trapped in low-productivity firms.

This analysis suggests several things. For one, exposing the textile sector to stronger external competition would not affect all firms in the same way. Stronger competition would likely drive some low-productivity textile firms out of the market, but at the same time, the high productivity dispersion suggests that there are also firms in the sector that could probably withstand foreign competition. External competition would lead these to reduce inefficiencies, upgrade their production processes through more advanced technologies, increase product quality and create new job opportunities (Pavcnik, 2002 [21]; Melitz, 2003 $[27]$.

\section{Figure 19. Protected sectors have dispersed productivity and low allocative efficiency}
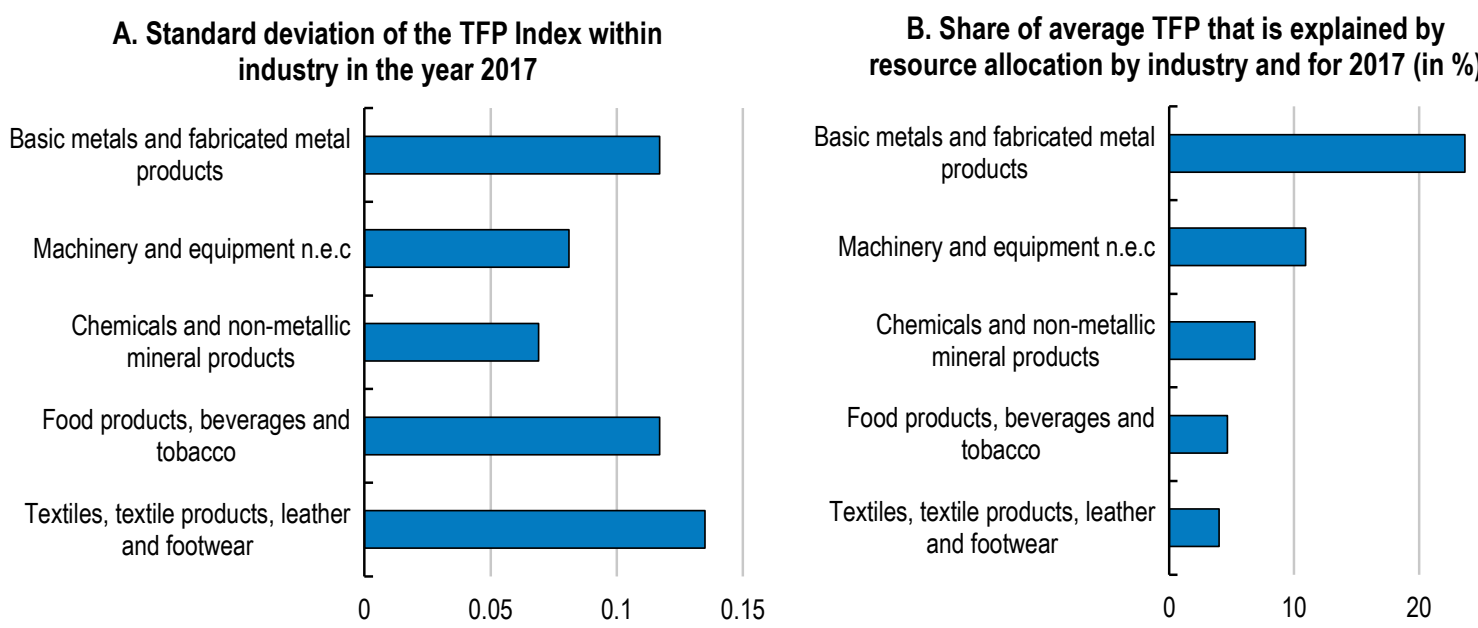

Note: Panel B shows the results from an Oley-Pakes-Decomposition of average total factor productivity (TFP) of industries into the part that is explained by the simple average of firm level TFP and the part that is explained by resource allocation across firms within an industry. The share that is explained by resource allocation is a commonly used measure for allocative efficiency in the sector. A more detailed description of the methodology can be found in Annex A.2.

Source: OECD calculations based on the World Bank Enterprise Survey.

StatLink הills http://dx.doi.org/10.1787/888933943265

Hence, if the sector were to face stronger competition from imports, the first expected reaction would be a movement of labour and capital towards more productive firms in the same sector. The disciplining effect of import competition could even provide opportunities for the most productive textile firms to start exporting to niche markets in advanced economies. As the high informality in the upper segment of the supply chain has so far complicated the establishment of a modern supply chain management, increasing external pressure to introduce quality control and certification systems could be key to open new export markets. This could end up providing new employment opportunities within the sector.

All this said, it is still possible that some textile workers may have to seek employment in other sectors, which may require new skills and appropriate income support. This calls for comprehensive education and training programmes for displaced workers, which should be closely coordinated with the private sector and focus on future skill needs. Moreover, effective income support and social protection for displaced workers, including those in the 
informal sector, are crucial for the success of the re-training programmes. However, given the strong heterogeneity of Argentinian textile firms, often cited fears of a complete shutdown of the sector with massive employment losses are not at all supported by the empirical evidence.

\section{The general equilibrium effects of stronger integration are positive}

The effects of trade policy changes tend to affect almost all parameters of an economy due to numerous feedback effects. One attempt to capture these effects is to undertake simulations in a computable general equilibrium model. Such models can capture the input linkages between economic sectors and also model markets for production factors, which are mobile across sectors. Thus, tariff changes affecting output in one sector also have repercussions on other sectors by changing the demand and prices for inputs and production factors. Moreover, these models also capture the feedback effects of changing income of workers and relative prices of goods and services on private consumption as well as the interlinkages of disaggregated sectoral trade flows.

To analyse the economy wide effects of a reduction in import protection for Argentina, simulations have been undertaken using the OECD METRO model, which links 61 countries and 57 economic sectors (Annex A.4). Simulations suggest that lowering currently applied tariffs unilaterally to the lowest levels among G20 countries would reduce input costs, increase production and exports and lead to rising real wages for workers. Total exports would increase by $4.7 \%$, while total imports rise by $3.5 \%$, indicating that the competitive pressure on domestic producers reduces prices, but does not lead to a strong substitution towards imported inputs and final goods. Total domestic production increases by $0.5 \%$ and real GDP by $0.3 \%$. It should be noted that these effects only comprise allocative efficiency effects. The static CGE model used for this analysis does not simulate further growth effects due to more efficient capital accumulation or sectoral productivity increases caused by better access to imported technology and intermediate inputs.

Importantly, as the tariff cuts lead to increases in total production and labour demand, real incomes increase for workers of all skill categories. In particular, unskilled workers benefit from lower trade barriers, as their real incomes rise by $1 \%$, largely on the basis of nominal wage improvements. The real labour income of clerks, service assistants, technical professionals, professionals and managers rises by around $0.5 \%$.

However, there is considerable heterogeneity in how the tariff reductions affect different economic sectors (Table 6). The model simulations suggest strong benefits for the motor vehicles and the non-ferrous metals industries, largely due to lower intermediate input costs (Annex Table A.4). Automobile production could increase by around 10\% and exports by almost $15 \%$. Other expanding sectors are agricultural and natural resource sectors and food processing. Demand for services would also rise, allowing expansion in transportation and professional business services, for example. All expanding sectors increase their labour demand for workers of all skill types and absorb the jobs shed in the shrinking sectors (Annex Table A.5). The sectors that may see moderate contractions are the textile and wearing apparel, the metal products, electronic equipment and the machinery and equipment industries. 
Table 6. Unilateral tariff decreases would boost production in agricultural and some manufacturing industries

Changes in sectoral production in reaction to a unilateral tariff cut (in \%)

\begin{tabular}{lc}
\hline \multicolumn{1}{c}{ Sector } & Percentage change (in \%) \\
\hline Cereal grains & 2.3 \\
Other agriculture & 0.6 \\
Oil seeds & 1.8 \\
Dairy & 1.0 \\
Natural resources & 0.9 \\
Meats & 0.5 \\
Food and beverage & 1.7 \\
\hline Textile and wearing apparel & -1.4 \\
Mineral products & -0.3 \\
\hline Ferrous metals & 1.2 \\
Nonferrous metals & 7.8 \\
Metal products & -1.9 \\
Motor vehicles and parts & 9.6 \\
Transport equipment & -0.3 \\
Electronic equipment & -0.9 \\
Machinery and equipment & -2.0 \\
Other manufacturing & 0.5 \\
Transportation & 1.4 \\
Communication & 0.6 \\
\hline Financial services & 0.5 \\
Insurance & 0.8 \\
Business services & 0.9 \\
Other services & -0.3 \\
\hline
\end{tabular}

Note: The results show the percentage change in sectoral production in reaction to a unilateral tariff cut in all sectors to the lowest levels among G20 countries.

Source: OECD calculations based on the OECD Metro model.

\section{Trade can generate new export opportunities}

As the economy integrates better into global trade, new export opportunities can emerge in sectors where Argentina has so far not had a strong export performance. A strong devaluation of the currency during 2018 has provided a boost to competitiveness, suggesting that now is a particularly appropriate time to seize new export opportunities. Improving access to competitively-priced intermediate inputs by lowering trade barriers would support this improved competitiveness of Argentinian producers.

Argentina's comparative advantage is apparent in products that are intensive in natural resources, e.g. agricultural and food products, but it is far from being confined to lowvalue-added activities. A detailed look at the economy's revealed comparative advantage (RCA), which measures how much a country exports of a given good relative to an average country, shows that at the product level, Argentina has revealed comparative advantages across many different industries (Figure 20). This applies to chemicals, pharmaceuticals and basic metals, but also machinery, rubber and plastics. Building on existing industrial clusters, and in particular the accumulated knowledge and skills, there are many opportunities for further diversifying the production system. 
Figure 20. Argentina has high potential in many products

Number of HS 6 digit products with revealed and latent comparative advantage by industry

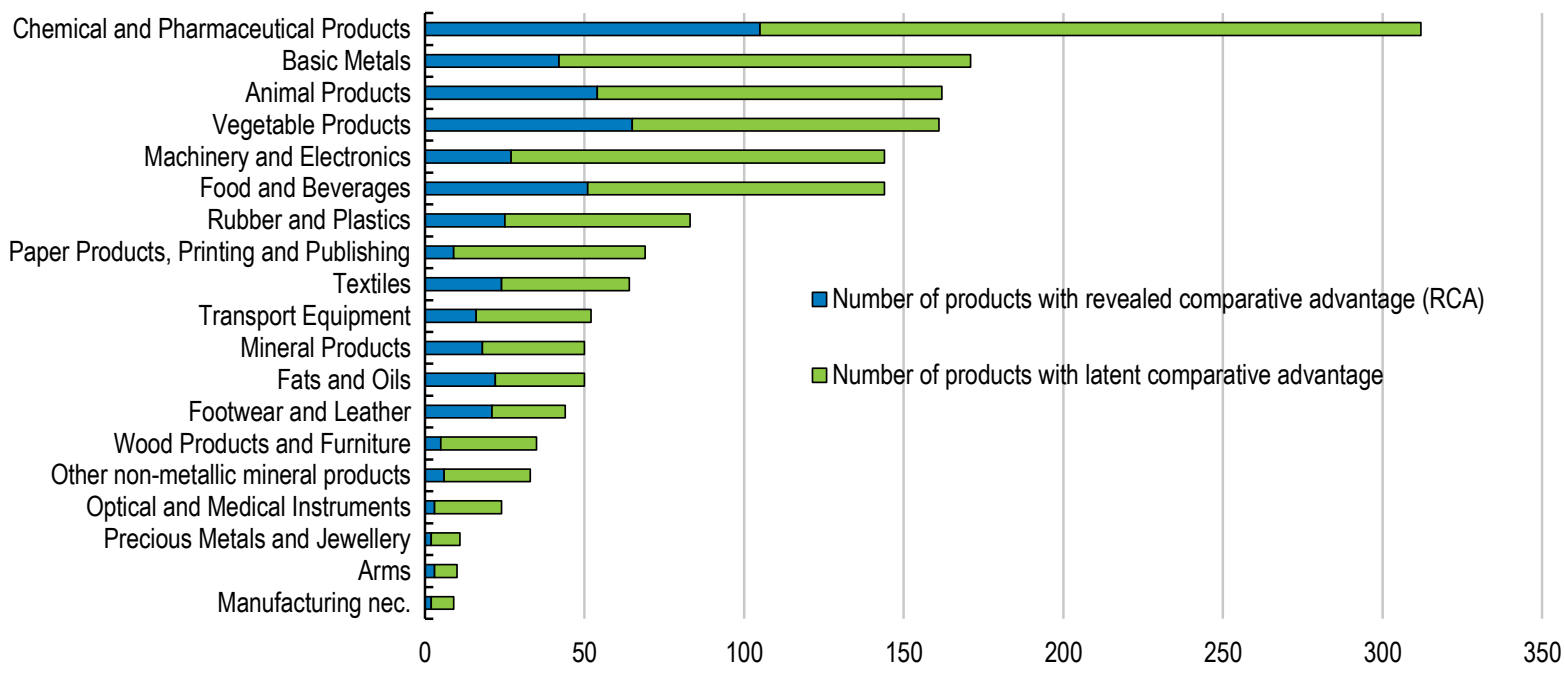

Note: A country has a revealed comparative advantage in the production of a product, if it exports relatively more of this product than an average country in the world. The graph shows the number of HS 6 digit products where Argentina has a revealed comparative advantage. The number of products with a latent comparative advantage is computed using network analysis and computing distances between products (Hidalgo et al., 2007[33]). Products with a latent comparative advantage are products that are close to products (in terms of skills and capital necessary to produce them) for which Argentina already has a revealed comparative advantage.

Source: (García Díaz and Dragún, 2019[34])

StatLink त्ञाजी https://doi.org/10.1787/888933943284

Two of the recent success stories of the Argentinian economy have been evolving without strong protection or large industry subsidies. Argentinian wine makers have seized the opportunities of a stable macro-economic environment and low import protection in the 1990s to invest in new production methods and machinery and diversify their product lines (Artopoulos, Friel and Hallak, 2013 ${ }_{[35]}$ ). Adapting to changing tastes in the major export markets and building on the strong comparative advantage of Argentinian soils, they increased their exports from from USD 25 million in 1993 to USD 650 million in 2008.

The second example concerns the impressive success of the Argentinian knowledge based services sector, whose exports grew from USD 151 million in 1996 to 6.5 billion in 2015 (Gayá, 2017 ${ }_{[7]}$ ). The sector is dominated by small and medium size firms, which due to a good digital infrastructure are relatively spread out over the country $(58 \%$ are in the greater Buenos Aires area), and have the potential to reduce regional disparities. Although there have been some stimulating incentives for parts of the sector through tax deductions (ley de software), the impressive dynamic is not explained by these incentives (Gayá, 2017 [7]; Oliveira, $\left.2018_{[36]}\right)$. Firms in this sector have built on the comparative advantages of Argentina in high skilled labour with good knowledge of English and a similar time zone with the United States.

\section{More integration will attract export-oriented foreign direct investment}

Foreign direct investment is an important source of external financing, but also key to increasing the integration of the economy into global value chains. In many emerging markets, supplying the domestic subsidiaries of foreign multi-national enterprises is one of 
the most promising ways for many small and medium size enterprises to increase their forward integration into global value chains (López González, 2017 $[37]$ ). This can act as a conduit for knowledge transfer and learning, enable domestic firms to adapt new technologies, production methods or better management practices and contributes to stronger productivity performance (Arnold, Javorcik and Mattoo, 2011 ${ }_{[38]}$; Blalock and Gertler, 2009 [39]). On the other hand, foreign direct investment also increases the use of foreign intermediate inputs in the domestic economy which stimulates knowledge and technology spill-overs raising productivity and exports of domestic firms (Lopez Gonzalez, $\left.2016_{[40]}\right)$.

In contrast to its high tariff and non-tariff barriers, Argentina has low restrictions on foreign direct investment (FDI) and ranks far below the OECD average according to the OECD FDI regulatory restrictiveness index. Nevertheless, during the last decade it has attracted far less foreign direct investment inflows than other Latin American countries such as Mexico or Brazil (Figure 21). The main reasons are macroeconomic and political instability, low infrastructure quality and high trade barriers. Other key factors that influence the stock of foreign direct investment are labour costs, institutional quality (corruption, the rule of law), skills or intellectual property protection (Cadestin, Gourdon and Kowalski, 2016 $[5]$ ).

Figure 21. Argentina attracts little foreign direct investment

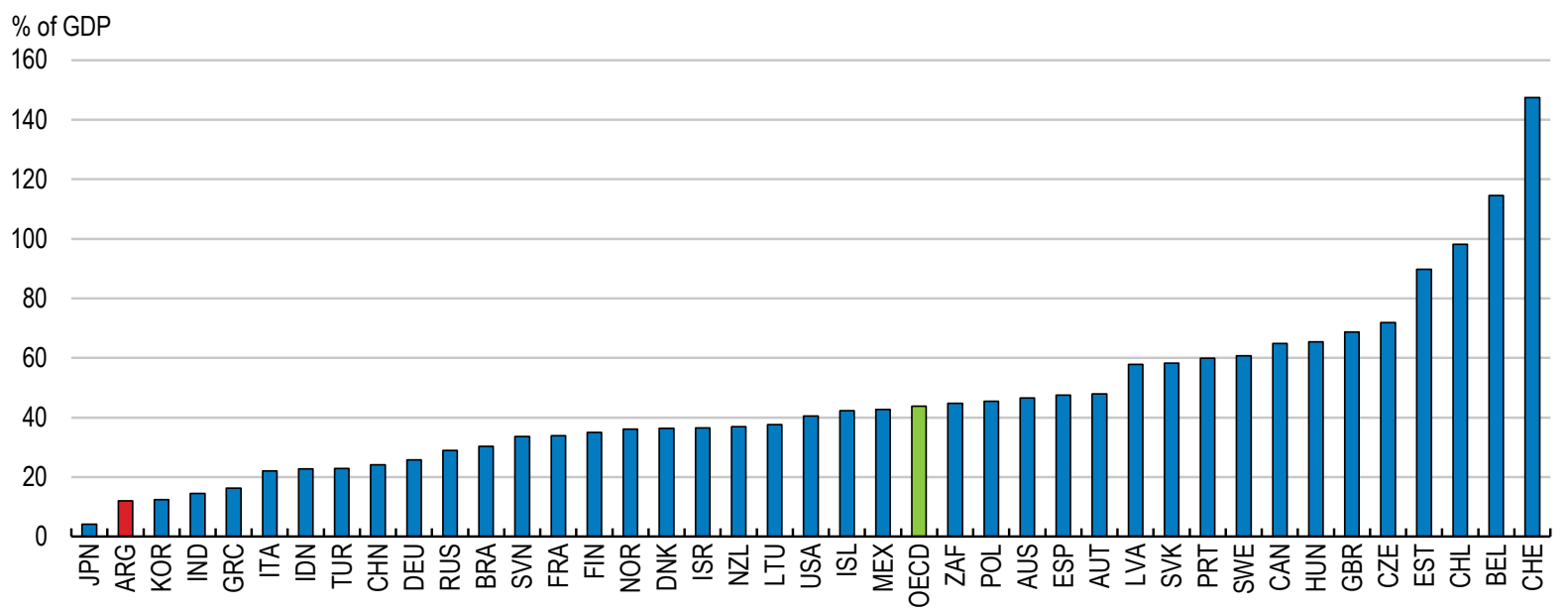

Source: CEPAL; and OECD FDI main aggregates database.

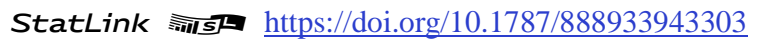

The objective behind incoming foreign direct investment influences its effects on the domestic economy. Foreign firms that conduct market-seeking investments are mainly focused on supplying the domestic market, often enticed by comparatively high prices, as has been the case of Argentina. In contrast, when foreign firms undertake efficiencyseeking investments, they benefit from the comparative advantage of a country, e.g. its natural resources, the supply of high skilled labour, or its institutional arrangements, which enables them to be more competitive and export to international markets. Because competition is higher in international markets, firms undertaking efficiency-seeking foreign direct investment have a strong incentive to use high quality inputs and capital 
goods as well as the most advanced technologies for their production. This explains why knowledge and technology spill-overs as well as productivity, employment and trade effects on the domestic economy are much higher for efficiency-seeking investments than for market-seeking investments (Barrientos, Gereffi and Rossi, 2011 ${ }_{[41]}$ ).

As market-seeking foreign direct investment focuses exclusively on the domestic market, it is attracted by protection of domestic markets which increases domestic prices and the economic rents for producers. In contrast, efficiency-seeking investments, which heavily depend on imported intermediate inputs and capital goods, are sensitive to high import barriers. When analysing the sectoral composition of the stock of foreign direct investment in Argentina for the year 2017, it appears that foreign direct investment flows in the last decade have been mostly targeting sectors with relatively high import protection, e.g. motor vehicles, pharmaceuticals, chemical and metal production (Figure 22). However, Argentina has also attracted foreign direct investments in sectors where it has a relative comparative advantage, such as food and beverage, the mining industries including oil and gas extraction as well as refined petroleum products.

Empirical analysis conducted for this chapter suggests that FDI inflows into specific sectors in Argentina since 2005 have tended to increase in reaction to higher import protection (Annex A.5). This indicates that foreign direct investment flows to Argentina are mainly oriented to the domestic market, possibly because they exploit the economic rents that are created through high import protection. As this type of foreign direct investment provides lower potential for technology and knowledge spill-overs to the domestic economy compared to efficiency-seeking investments, a reduction in import barriers might allow Argentina to attract more export-oriented foreign direct investments, which would have strong positive effects for productivity and employment (Barrientos, Gereffi and Rossi, $\left.2011_{[41]}\right)$.

Argentina has the potential to become an attractive destination for efficiency-seeking foreign direct investment. A convenient time zone with respect to US or Europe, which is crucial for companies requiring real time communications with customers or headquarters, and good English language skills among tertiary graduates are strategic advantages not fully exploited by international companies so far. Especially, the professional business services, IT and software services are attractive sectors that are already booming in Argentina, but do not receive large amounts of foreign direct investment. Other promising sectors for further foreign direct investment are the mining and energy sector including oil and gas extraction and renewable energies, the petrochemical industries as well as agriculture and the food and beverage industries.

Moreover, some of the industries that have been growing due to high import protection might also start being attractive for efficiency-seeking foreign direct investment. For example, the pharmaceutical and medical instruments industry has been growing strongly and is already exporting to many other Latin American countries. However, for these protected industries as for other industries to flourish in the future and to attract efficiencyseeking investments, it is key to reduce import protection and enable the access to a larger variety of cheaper and higher quality inputs. 
Figure 22. Stock of foreign direct investment by sector in 2017 (in Million USD)
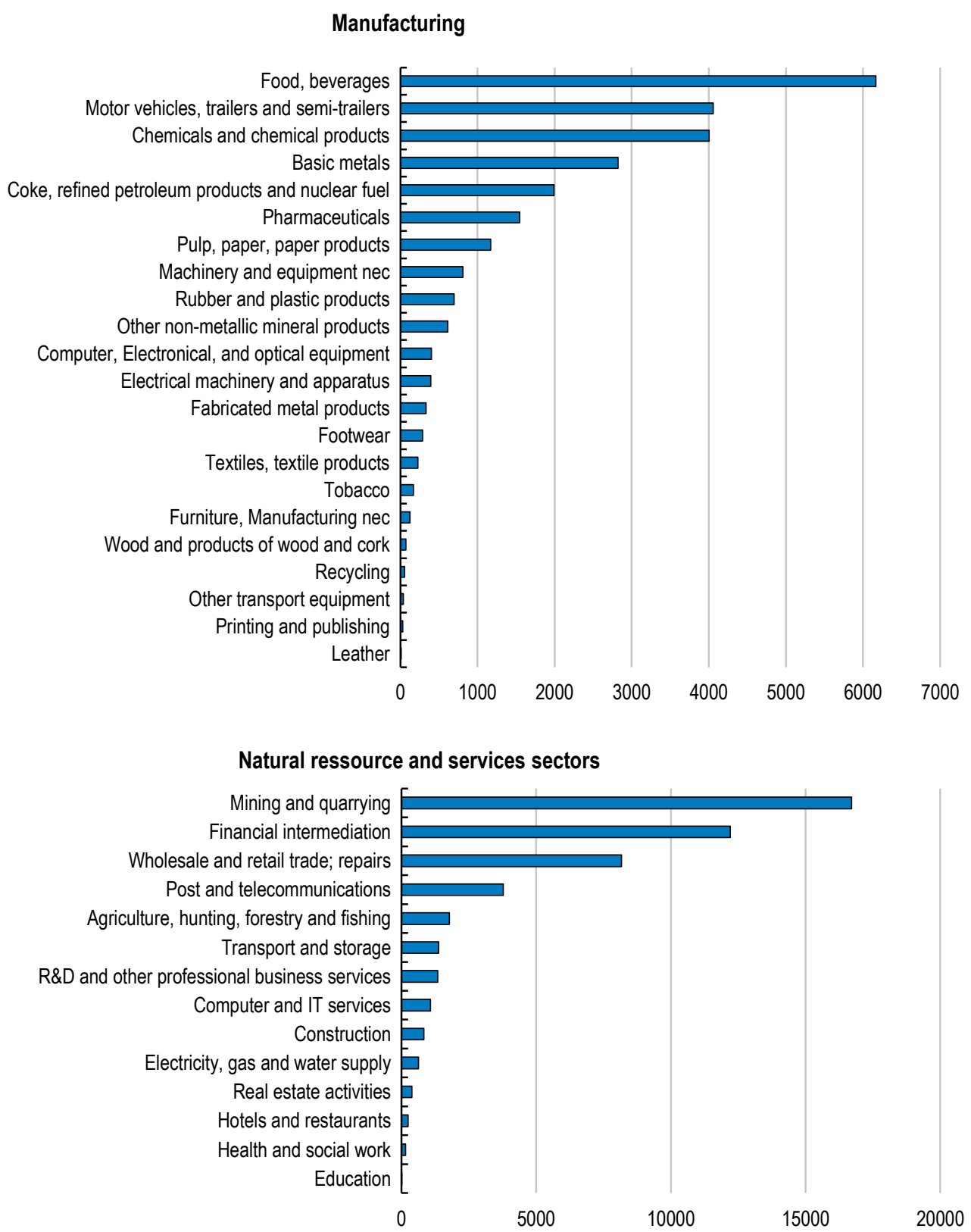

Source: Banco Central de la República Argentina (BCRA) (2018).

StatLink *iाls ht htps://doi.org/10.1787/888933943322

Furthermore, to attract more and higher quality foreign direct investments, it is crucial to ensure longer-term macro-economic and political stability. It is also important that the 2017 tax reform will be implemented over the next five years, as the current distortive and unfair tax system continues to be one of the main obstacles for doing business in Argentina (Schwab, 2018 $\left.{ }_{[42]}\right)$. A strong and decisive commitment to strengthen the rule of law and fight corruption would help to increase the trust in government institutions, especially as in recent months the public procurement and infrastructure planning system of the previous government has been exposed to large scale corruption accusations. Moreover, 
improvements in the efficiency of the legal and judicial systems to settle disputes are necessary, as this continues to be signalled by investors as an important impediment to do business in Argentina (Schwab, 2018 $8_{[42]}$ ).

Finally, the recent real depreciation of the Argentinian peso has considerably increased the international competitiveness and attractiveness of Argentina for foreign direct investment and may present a good opportunity for attracting more and new forms of investments (Figure 24).

\section{Trade policy options for fostering stronger integration into the global economy}

Defining a concrete policy agenda for integration requires a reflection on the different options for trade policy reform, given Argentina's current agreements and obligations. It will also require thinking about the role of international trade negotiations. Finally, finding the right sequencing can matter significantly to maximise the benefits of trade.

\section{Space for lowering trade protection with and without Mercosur partners}

Argentina is a member of the MERCOSUR trade bloc, which has helped to strengthen trade linkages with the other members, in particular Brazil. At the same time, the exchange of goods and services with the rest of the region is weak (IMF, 2017 ${ }_{[43]}$ ). Bilateral trade negotiations between MERCOSUR and external trading partners would be an obvious way forward as they allow achieving better market access in return. Tariffs faced by Argentinian exports average at $4.12 \%$, but this number hides substantial heterogeneity. Some promising export markets for Argentinian agricultural and food products like China and India levy average applied tariffs on food and beverages of $12 \%$ and $65 \%$, respectively. Besides tariffs, Argentinian exports also face particularly high non-tariff measures with an average ad-valorem equivalent of around 20\% (Cadot, Gourdon and van Tongeren, 2018 ${ }_{[14]}$ ).

Historically, the MERCOSUR has not pursued an active strategy of seeking new trade agreements with other countries. It has only signed bilateral agreements covering about $10 \%$ of world GDP. For comparison, Peru and Chile have already signed trade agreements covering about 70-80\% of world GDP. The traditionally passive stance of the MERCOSUR has changed recently, with trade negotiations ongoing or planned with the European Union, the Andean Community, the Pacific Alliance, South Korea and Canada. The implementation of the recently negotiated trade agreement with the European Union, in particular, will make a big difference as it will imply integration with a large and competitive market.

Argentina should continue to play a leading role in trade negotiations, as lower trade barriers in current and potential export destinations could provide a significant boost to Argentina's exports. In particular, efforts should also focus on reducing non-tariff measures in export markets, as these are especially burdensome for agricultural and food products as well as the other main export products from Argentina (Box 1). Items of interest to Argentina include quantitative import restrictions, the harmonisation of product standards between countries or the mutual recognition of certification systems for product quality assessment (Maskus and Wilson, 2001 [44]).

Negotiations should also include services sectors. IT, software and other professional business services account for $10 \%$ of total exports in goods and services and face significant service trade restrictions in major export markets as well as potential markets (Figure 23). 
Figure 23. Argentina's services exports face high barriers in its main current and potential export markets

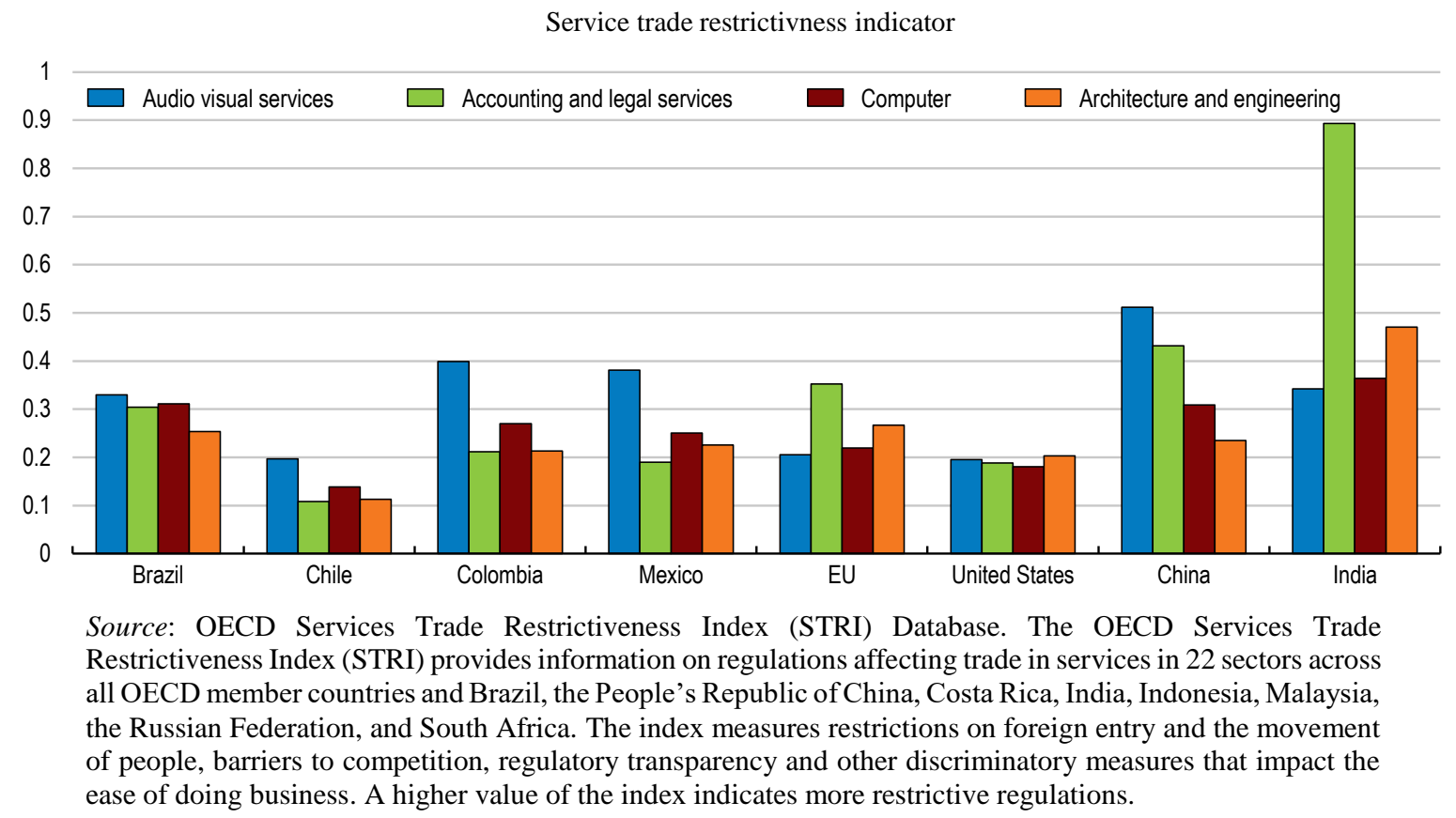

StatLink 제 जी https://doi.org/10.1787/888933943341

At the same time, the sometimes glacial pace of trade negotiations and the risk that they may not lead to a significant agreement at all implies that pursuing only bilateral negotiations could be a risky bet. Given how closed the economy is and how large the potential benefits of stronger integration into the global economy are, efforts to lower trade barriers should go beyond bilateral negotiations. Many Asian countries as well as Chile pursued a strategy of liberalising unilaterally in addition to regional and bilateral agreements, with tariffs often reduced for the purpose of attracting investment (Baldwin, $\left.2006_{[45]}\right)$.

In the short term, Argentina has several main avenues for reducing its own trade barriers. First, Argentina could use its margin for tariff adjustment within the current MERCOSUR agreement. Member countries have the right to undertake unilateral changes to common tariffs in about $30 \%$ of tariff lines, which -if chosen strategically- could have a major impact (Olarreaga and Soloaga, 1998 $\left.{ }_{[46]}\right)$. Second, the MERCOSUR agreement does not preclude member countries from changing its non-tariff measures (Bown and Tovar, 2016 $\left.{ }_{[47]}\right)$. Third, Argentina could work together with MERCOSUR trading partners to evaluate the scope of consensus for specific unilateral reductions of the bloc's common external tariff.

\section{Finding the best sequencing}

A quick materialisation of positive effects and the minimisation of adjustment costs depend crucially on finding the best sequencing of policy reforms. However, while some trade reforms may not be part of a possible first set of measures, these should not be pushed into the far future as the current macro-economic environment provides a unique opportunity for a reduction in import barriers. The real depreciation of the currency has increased the international competiveness of Argentinian firms, which mitigates substantially the 
adjustment costs that some sectors and firms would face due to increasing import competition (Figure 24).

Figure 24. The real devaluation has increased competitiveness

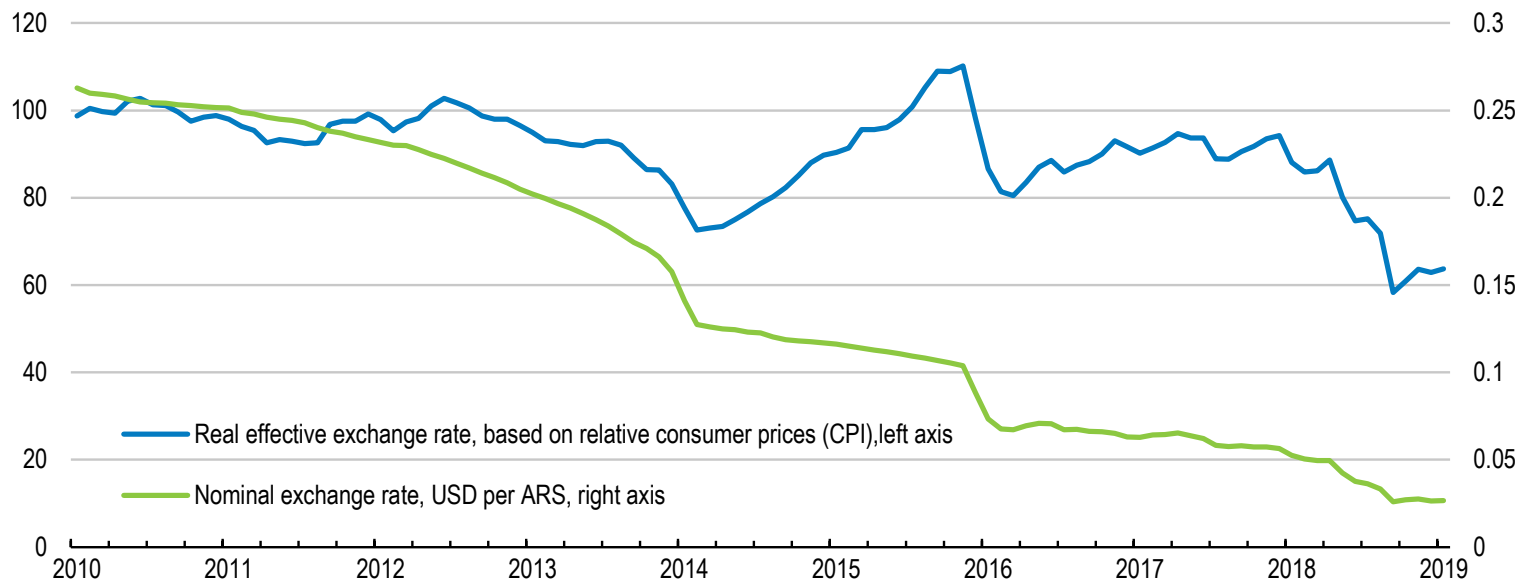

Note: A decrease in the real exchange rate signals that that the USD prices of Argentinian products decreased relative to prices of foreign products (left hand scale), implying that the Argentinian economy has gained competitiveness in international markets. The right hand scale shows the value of the nominal exchange rate in USD per ARG Peso.

Source: OECD ADB database.

StatLink त्गाड़ https://doi.org/10.1787/888933943360

In light of the strong empirical evidence underpinning the benefits of better access to inputs, sectors providing key intermediate inputs to other parts of the economy, but also capital goods, should be a first priority. This would benefit all sectors of the economy and in turn help to boost exports, as with expanded access to modern technology embodied in foreign inputs local companies can become more productive and competitive in global markets (Amiti and Konings, 2007 $[1]$ )

Scaling back non-tariff measures such as non-automatic import licenses could also be frontloaded, as these measures are non-transparent and the effective protection resulting from such measures sometimes even exceeds tariff rates. Moreover, Argentina has the power to remove non-tariff measures without delay and without consulting with its partners. This opens space for a thorough revision of non-automatic import licenses with a view towards limiting them to a minimum, for example to areas where public health concerns exist.

Reducing tariffs in intermediate sectors and eliminating most non-tariff measures would be an obvious first step, and could happen immediately. In the current fiscal context, it is important to bear in mind that this would not result in significant fiscal losses as total tariff revenues currently amount to around $0.7 \%$ of GDP and the productivity effects of better integration would likely lead to an expansion of activity and additional tax revenues. Estimations conducted for this report indicate that reducing current trade barriers to the average levels of the regional peers Chile, Colombia and Mexico, would lead to a yearly increase of GDP per capita by around 1.3\% over the next ten years (Table 1 in Key Policy Insights).

Furthermore, some intermediate inputs and capital goods that are not produced in Argentina are subject to import protection. For example, the government has recently reduced tariffs for some selected intermediate and capital goods with high technology content and no 
domestic production to about $2 \%$. For these type of products, the adjustment costs of fully eliminating import barriers would be minimal. The temporary admission regime, which allows firms to import inputs without paying tariffs in case the final product is exported, is a step into the right direction, but should be extended to firms producing for the domestic market.

Sectors that do not provide major inputs into other activities, including the textile sector which employs a large fraction of the low-skilled workforce often in informal work conditions, could instead be subjected to a gradual, pre-announced and steady reduction of protection. That would encourage firms to upgrade their technologies and become more competitive. Communicating a clear and credible time line for phasing out trade barriers could be a useful instrument, although it may be hard for policy makers to make credible commitments to lower protection. Greater international commitments, for example in the context of bilateral negotiations, could help ensure that barriers continue to be reduced .

In the meantime, policies should be put in place to mitigate the social impact of lower trade barriers in the remaining sectors, particularly those where overall employment may decline and workers may need to move to other sectors. This may require new skills, and training policies geared towards workers in sensitive sectors hold large potential to smooth the transition. Putting in place such active training policies may have a high pay-off independently of trade policy reforms, as some sectors where employment losses are conceivable, such as textiles and apparel, have a high share of informal employment. Better training could allow some of those employed there to find formal employment in other parts of the economy.

After some transition period, a gradual and pre-announced elimination of tariffs and NTMs for final consumption goods can do much to raise productivity and real wages in Argentina, both through the emergence of new job opportunities and through declining consumer prices, with particularly visible benefits for poorer households.

\section{Increasing market access for Argentinian exports}

In parallel to these unilateral reductions in import barriers, Argentina could bilaterally negotiate lower barriers in its export markets due to non-tariff measures, e.g. product standard regulations and enforcement (Box 1). Recent successful negotiations with China about the market access of Argentinian meat show that there is large scope for such bilateral negotiations (Clarin, 2018 ${ }_{[48]}$ ). Further opening the Chinese market for Argentinian food products would strengthen exports, employment and value added creation in the Argentinian food processing industry.

Another good example is the end of a 16-year long ban of Argentinian lemons and lemon products in the U.S. which was negotiated by the Argentinian government in 2017 (Polansek, 2017 [49] ; Jouanjean, 2012 ${ }_{[50]}$ ). This is a major opportunity for the production of lemon and lemon juice in the Northern provinces of Argentina and a support to regional employment.

Additional firm-level analysis conducted for this report finds that Argentinian firms with an internationally recognised quality certification for their products have on average a $2.1 \%$ higher total factor productivity compared to firms without such a certification (Annex A.2). This emphasises the potential benefits from improving the domestic quality testing system and obtaining international recognition for the quality assessment certifications issued by the Argentinian authorities. 


\section{Box 1. Product standards and their enforcement might pose significant barriers to Argentina's exports to advanced economies}

Non-tariff measures (NTMs) like product standards and technical regulations have increased in importance in advanced countries compared to tariffs that are at historical lows (Baldwin and Evenett, 2009 $[8]$ ). Although product standards are imposed to overcome market failures and protect the health of domestic consumers, they can act as significant import barriers, in particular for exports from emerging markets (Maskus and Wilson, $\left.2001_{[44]}\right)$. Recent empirical research suggests that product standards and their enforcement have also been used to protect industries in advanced economies (Trefler, 1993 [51]; Essaji, 2008 ${ }_{[52]}$; Grundke and Moser, 2019 $\left.{ }_{[11]}\right)$.

Argentina's exports have also been subject to refusal of market entry due to noncompliance with product standards in the U.S. and the EU (Figure 25). Although the number of refused shipments per se does not inform about the refused trade volume, the negative reputation effects of import refusals on other firms in the same export sector are substantial and lead to reduced market access and decreasing exports (Jouanjean, Maur and Shepherd, 2012 ${ }_{[53]}$; Grundke and Moser, 2019 $\left.9_{[11]}\right)$. This particularly affects exporters from emerging markets highlighting the necessity of a comprehensive approach to upgrading product standards systems and building compliance capacity, focusing on sectors rather than individual products. This also entails establishing a system of product quality assessment, which provides certificates that are recognised by the enforcement authorities in export markets.

Figure 25. Argentina's products face issues with product standard regulations in its main export markets

Number of Argentina's product shipments refused entry into important export markets due to noncompliance with product standard regulations

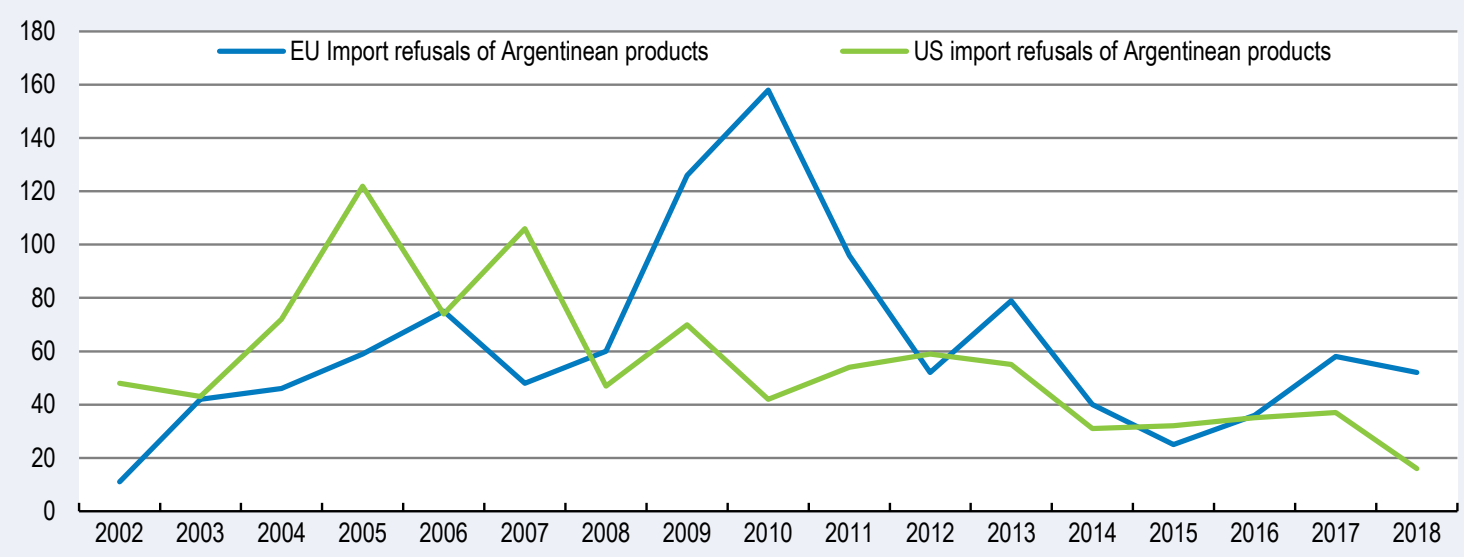

Note: The EU RASFF database only publishes EU import refusals and notifications for food and animal feed products. Thus, any other manufacturing products are not included in the database. The US FDA database includes information on import refusals of food products, pharmaceuticals, cosmetics, medical devices and a wider range of electronic products.

Source: RASFF database for EU refusals and US FDA Import Refusals Report (IRR) database for US refusals.

StatLink त्राजम https://doi.org/10.1787/888933943379

In the U.S., Argentina mainly faces market access issues for its exports of pharmaceuticals and medical devices (Table 7). The main reasons for these import refusals are issues related to certification requirements or product labelling. Thus, it seems that no fundamental 
problems in the production structure exist that would impede Argentina to produce the necessary product quality for U.S. markets. A comprehensive initiative of the Argentinian government to support domestic producers of pharmaceuticals and medical devices should comprise a close cooperation of the Argentinian authorities for product quality assessment with the U.S. Food and Drug Administration. This should aim at reducing information and compliance costs for domestic producers, concerning certification, listing and labelling requirements. This would be a much more cost efficient and effective support for this industry than the high import barriers that still exists for medicaments and medical instruments (which hurt domestic consumers and increase the costs of the public health system in Argentina).

Table 7. Pharmaceuticals and medical devices from Argentina have difficulties to enter the US market due to certification issues

Five most refused product categories and five most frequent reasons for Argentinian products that have been refused entry into US markets (2002-2018).

\begin{tabular}{|c|c|c|c|}
\hline $\begin{array}{l}\text { Five most refused product } \\
\text { categories }\end{array}$ & $\begin{array}{l}\text { Number of shipments } \\
\text { refused (products) }\end{array}$ & Five most frequent reasons & $\begin{array}{l}\text { Number of shipments } \\
\text { refused (reasons) }\end{array}$ \\
\hline $\begin{array}{l}\text { Other medicaments, except } \\
\text { antibiotics and hormones }\end{array}$ & 201 & $\begin{array}{l}\text { It appears the drug or device is not included in a list as } \\
\text { required by the FDA. }\end{array}$ & 220 \\
\hline $\begin{array}{l}\text { Medical instruments, machines } \\
\text { and other medical device }\end{array}$ & 128 & $\begin{array}{l}\text { The article appears to be a new drug without an } \\
\text { approved new drug application. }\end{array}$ & 188 \\
\hline $\begin{array}{l}\text { Fresh and dried fruits, fruit and } \\
\text { vegetable juices }\end{array}$ & 119 & $\begin{array}{l}\text { It appears that the manufacturer has not filed } \\
\text { information on its scheduled process as required. }\end{array}$ & 135 \\
\hline Skin care and make up & 41 & Required label or labelling appears to not be in English & 127 \\
\hline Hormones and insulin & 29 & $\begin{array}{l}\text { The article appears to consist in whole or in part of a } \\
\text { filthy, putrid, or decomposed substance or be otherwise } \\
\text { unfit for food. }\end{array}$ & 92 \\
\hline
\end{tabular}

Note: The US FDA database includes information on import refusals of food products, pharmaceuticals, cosmetics, medical devices and a wider range of electronic products.

Source: US FDA IRR database.

In the EU, nuts, meat and animal feed products from Argentina have particular issues entering the EU market (Table 8). Policy efforts to increase market access to the EU should mainly focus on improving the sector-specific systems for product quality controls. Noncompliance of one exporting firm can hurt the reputation of the whole sector and have significant negative effects on exports to the EU.

Table 8. Some food products from Argentina have difficulties to enter the EU markets due to non-compliance with EU product standards

Five most refused product categories and five most frequent reasons for Argentinian products that have been refused entry into EU markets (2002-2018).

\begin{tabular}{|lclc|}
\hline $\begin{array}{c}\text { Five most refused product } \\
\text { categories }\end{array}$ & $\begin{array}{c}\text { Number of shipments } \\
\text { refused (products) }\end{array}$ & \multicolumn{1}{c}{ Five most frequent reasons } & $\begin{array}{c}\text { Number of shipments } \\
\text { refused (reasons) }\end{array}$ \\
\hline Nuts, nut products and seeds & 499 & Aflatoxin content too high & 502 \\
Meat and meat products & 164 & Salmonella in product & 146 \\
Animal feed materials & 134 & Shigatoxin content too high & 63 \\
Fish and fish products & 88 & Bad temperature control & 41 \\
Fruits and vegetables & 78 & $\begin{array}{l}\text { Substance not authorised by EU authorities } \\
\text { (mostly genetically modified) }\end{array}$ & 35 \\
\hline
\end{tabular}

Note: The EU RASFF database only publishes EU import refusals and notifications for food and animal feed products.

Thus, any other manufacturing products are not included in the database.

Source: EU-RASFF database. 
Since 2016, the government has worked closely with the private sector to identify priority products and destinations, generate information about potential barriers and define a strategy to negotiate foreign market access. Since January 2016, market access for 160 products has improved in more than 40 countries. These efforts have recently been complemented by a national export strategy ("Argentina Exporta"), which among other areas features a newly created national product quality system to ensure compliance of products with product standards in export markets. Other items in the agenda include access to finance, infrastructure, trade facilitation, export promotion and the dissemination of best practices through corporate networks.

In this context, Argentina should try to make further advances in trade facilitation, which could reduce costs for exporting firms significantly (Figure 26). Administrative burdens on exports and imports are higher than in Brazil, Chile and Mexico and the efficiency of customs and border clearance in Argentina has strongly decreased during the last decade, according to World Bank's Logistics Performance Index. Harmonising procedures into a single electronic document and consolidating information and certifications from various authorities, such as customs or health and agriculture, can significantly increase efficiency in customs and reduce associated costs (Sarmiento, Lucenti and Garcia, 2010 ${ }_{[54]}$ ).

Figure 26. Trade facilitation can be improved

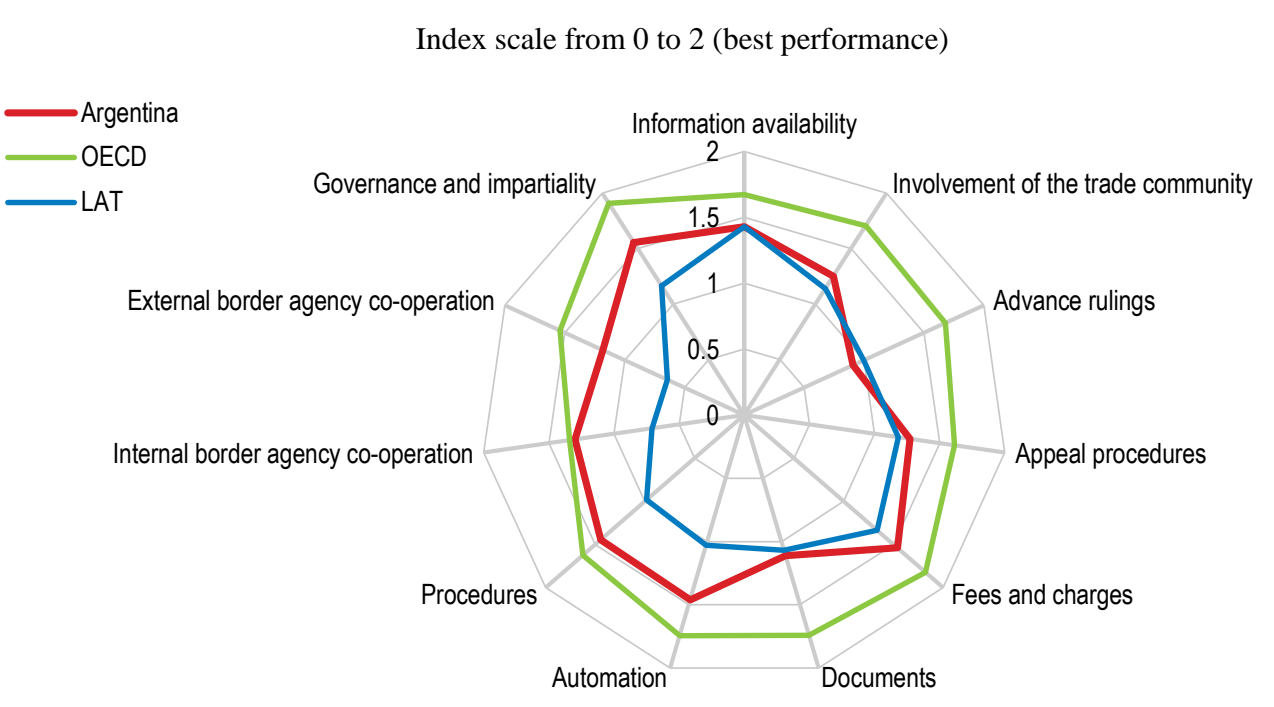

Note: Data is for the year 2017.

Source: OECD Trade facilitation indicators database.

StatLink त्गाs ht htps://doi.org/10.1787/888933943398

Argentina has already made an important step in this direction by lancing the first implementation phase of an online one-stop shop mechanism for exporting (VUCE), which already includes more than 280 administrative procedures and reduces time spent on these procedures by 65 percent. The full implementation is planned for 2020 (Iglesias, 2018 ${ }_{[55]}$ ). Continuing to modernise and simplify customs procedures is crucial to improve export performance (Moïsé and Sorescu, 2013 ${ }_{[56]}$ ). This would also help to reduce the scope for corruption, especially through the establishment of online procedures that eliminate personal interactions. For small firms (with exports up to USD 600000 per year), the government has also established a program to simplify export logistics ("Exporta Simple"). 
Beyond simplifying customs procedures, a cost-effective way to improve trade facilitation is through more cooperation, both among various agencies of the country as well as with neighbouring and third countries (Figure 26). Increasing cooperation with border agencies of other countries and engaging in mutual recognition agreements concerning certifications for product quality assessment would significantly facilitate imports and exports (Box 1). Moreover, a systematic sharing of inspection results of product standard enforcement agencies among neighbouring countries would improve the risk analysis as well as the efficiency of border controls and would facilitate intra-regional trade. The Rapid Alert System for Food and Feed (RASFF) established by EU member countries could serve as a good example. Argentina could also benefit from a harmonisation of data requirements and documentary controls among domestic agencies involved in the management of cross border trade, as established in other countries in the region such as Peru and Mexico.

\section{Easing the transition: Policies to support the structural transformation}

It is important to acknowledge that trade opening typically combines strong medium-term benefits, such as more and better jobs, with short-run adjustment costs as jobs will be lost in some firms, sectors and regions, and created in others. Policies can go a long way to reducing the burden of adjustment for poor and vulnerable households and ensure that all Argentinians benefit from trade. In particular, it is crucial that those that may initially struggle with the transition get adequate support so that they can find new employment opportunities. This is also of particular relevance to gain political support for a stronger integration into the global economy.

Policies to ease the transition can have several dimensions. The most urgent one is to protect workers in the transition by ensuring that adequate social protection, but also adequate training opportunities are put in place. These policies also need to consider the regional dimension of the structural transformation, as certain highly protected industries are concentrated in specific regions, e.g. the electronics industry in the province of Tierra del Fuego or the textile industry in the greater Buenos Aires area. The central government should closely coordinate the necessary policies with provincial governments, in particular because provincial governments have most of the authority over education and training policies and hence play a key role in the structural transformation.

Beyond this, structural policies can reduce frictions and facilitate the structural transformation of the economy (Box 2). Reducing import protection will entail a significant reallocation of resources, i.e. labour and capital, across sectors and within sectors across firms. Allowing this to happen is a precondition for reaping the benefits of stronger integration. Well-functioning product and labour markets play a key role in this context. Finally, innovation is one of the pillars of long-run productivity and competitiveness, with well-designed policies playing a key role in strengthening the incentives to innovate. The successful implementation of these complementary structural reforms will have a bearing on the magnitude of the adjustment costs that workers in import competing sectors and less productive firms will face in the short run (Winters, Mcculloch and Mckay, 2004 ${ }_{[3]}$ ). 


\section{Box 2. Successful examples of policies to complement the structural transformation}

Episodes of structural transformation across OECD countries can offer valuable insights about how policies can facilitate adjustments to changes in economic structure. The cases of the Basque Country in Spain and the Ruhr area in Germany exemplify how a coherent and stable policy package can facilitate transformation and lead to jobs and opportunities in new areas.

In the 1970s and 1980s, the Basque Country underwent a significant restructuring of its economy following the decline of traditional sectors such as steel, shipbuilding and machine tools, which led to high unemployment. Regional policies put the focus on technological upgrading as a way to restore the international competitiveness of the manufacturing sector. This included strengthening the existing but weak technology infrastructure, promoting R\&D activities by firms, creating technology parks and developing training programmes for workers and researchers $\left(\right.$ OECD, 2011 $\left.1_{[57]}\right)$. This strategy, pursued with stability and continuity over time, paid off in the end. The Basque Country now has a strong business-oriented innovation system and has technological strengths in machinery and equipment. Business R\&D is double the national average and is also in the top $25 \%$ of OECD regions and countries (OECD, 2014 $\left.4_{[58]}\right)$. The export performance of the region has improved markedly, driven by goods with a higher technological content (such as aeronautics or telecommunications) and also due to the innovation carried out in traditional industries such as automobile and tool-machinery. Knowledge-intensive services sectors have also gained weight, particularly in areas linked to manufacturing (e.g. engineering and consultancy). The Basque Country is now the region with the lowest unemployment rate in Spain and GDP per capita is 25\% above the European Union average.

The Ruhr region used to be one of the most important industrial regions of Europe, with strong coal mining and steel industries. With a shrinking global demand and a loss of international competiveness, the Ruhr area faced the challenge to restructure its economy. To respond to that challenge, regional policies changed the focus towards environmental technology. Enterprises shifted away from coal and steel and invested in plant engineering, control services and environmental technology. The move into the field of environmental technology has its root in the search for new ways to reduce pollution emitted by traditional coal and steel industries (Galgóczi, 2014 ${ }_{[59]}$ ). As these industries required significant energy resources and produced a lot of waste, the region benefited from an existing comparative advantage in energy production and waste disposal. Building on that comparative advantage, the focus was on stimulating $\mathrm{R} \& \mathrm{D}$ in the fields of renewable energy resources, recycling and waste combustion. Nowadays, the Ruhr area is the centre of environmental technology research in Germany, underpinned by local universities, research centres and local firms. Labour market policies were also part of the strategy, as agencies specialised in job counselling and training took care of facilitating labour market transitions of affected workers. The change in the employment structure of the area was large; manufacturing and services sectors accounted for $60 \%$ and $36 \%$ of employment, respectively, at the beginning of the 1960s. By 2000, manufacturing employed $33 \%$ and services $65 \%$ of the total workforce. 


\section{Improving training and social protection}

Opening up to the world economy tends to have pro-poor effects in emerging market economies (Porto, 2006 $[16])$. In the medium run, workers stand to gain from new job opportunities, as jobs created in exporting firms are more likely to be formal and to pay better. Argentinian exporters pay 31\% higher wages than non-exporters (Brambilla, Depetris Chauvin and Porto, 2017[24] $)$. However, for some workers, reallocations will involve the need to search for a new job. Argentina has high job turnover rates with more than $18 \%$ of employees changing jobs within one year (Pieczynski, 2016 $\left.{ }_{[60]}\right)$. Hence, more firm turnover in the adjustment period is probably a manageable burden for those who find new employment in the same sector. However, when entire sectors contract and workers have to learn new skills or move geographically, the adjustment costs may be more substantial.

Scaling up active labour market policies and providing training opportunities is a key policy lever in this context. Training can help workers to get ready for new jobs in expanding sectors, and even enhance their chances of accessing better paying jobs. Argentina spends slightly less than the average OECD country on active labour market policies, and roughly half of the OECD average for training measures (Figure 27). Expanding the offer of training opportunities, which should also aim at including adults currently outside of the labour market, may require a need to spend more on adult training. Space for this may be found by reallocating some resources from public works schemes, which make up almost $80 \%$ of Argentina's expenditures on active labour market policies (ILO, 2016 $[61]$ ).

Training policies may have a durable impact on employability by improving the beneficiaries' income-generating potential. Benefits can be significant especially for women (Bergemann and Van Den Berg, 2006 $6_{[62]}$ ). Possible training measures include formal education courses to upgrade general cognitive skills through general education training programmes for adults, as for many low skilled workers the move to other jobs and occupations would require a higher level of cognitive skills (Bechichi et al., 2018 ${ }_{[63]}$ ). However, this is only an intermediate step. This general training needs to be accompanied by upgrading and learning new task- and job-specific skills, which will also be necessary for middle and high skilled workers that need to move to new jobs. The content and the implementation of the necessary training should be closely coordinated with the private sector to address current and future skill needs.

Several Latin American countries, including Chile, managed to make labour market policies more effective by adding an active labour market component, such as training and education, to existing conditional cash transfer programmes (Cecchini and Madariaga, $\left.2011_{\text {[64] }}\right)$. Cash transfers provide income support in times of need but they can become more effective if supplemented by a training component that improves participants' chances to find more autonomous and sustainable income generation opportunities.

The experience of Argentina with these types of programmes is positive. Empirical evaluations suggest that participation in a scheme combining a cash transfer with training is associated with better wages and higher chances of accessing formal employment (Lopez Mourelo and Escudero, 2017 $\left.{ }_{[65]}\right)$. Thus, expanding such schemes can be an effective way to provide support to those more affected by the reallocation process that the Argentinian economy has started and, at the same time, empower participants to benefit from the new jobs that Argentina will be creating. Recently established cash transfers to adults who return to school or acquire professional training are a step in this direction and have been taken up by 260000 adults. 
Figure 27. Spending on active labour market policies is below the OECD average

\section{A. Public expenditure on active labour market policies}

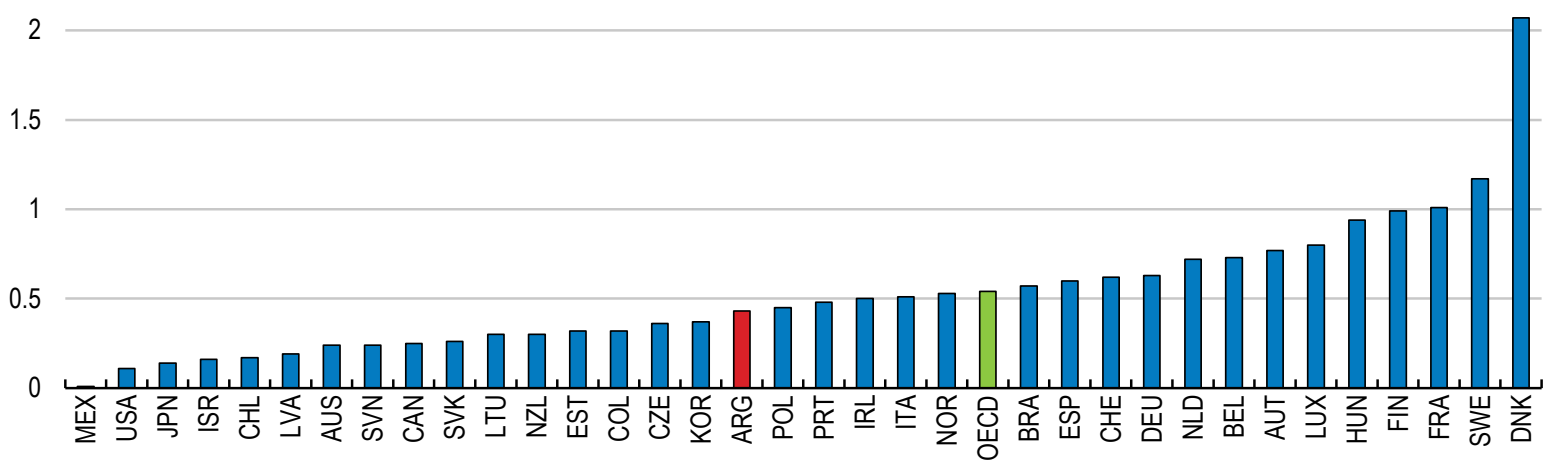

B. Public expenditure on training-based active labour market policies 2016 or latest year available

\section{6}

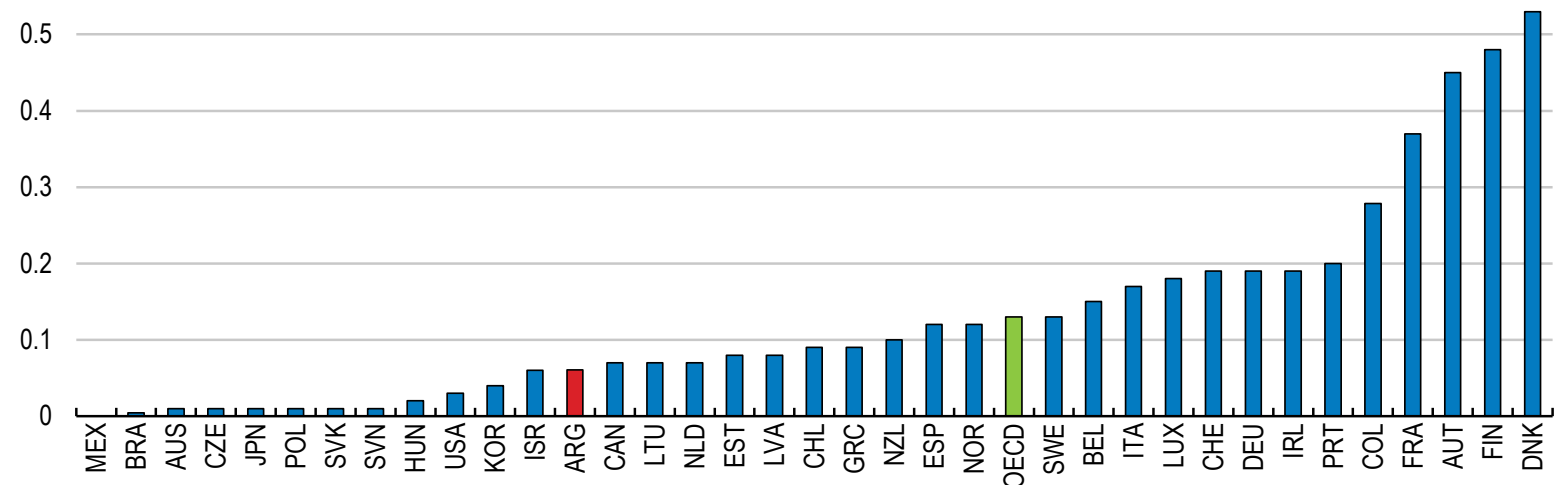

Source: OECD database on public expenditure and participant stocks related to active labour market policies; ILO.

\section{StatLink הत्रा ht htp://dx.doi.org/10.1787/888933942828}

Another recent government programme ("Programa de Transformación Productiva") focuses directly on the consequences of the structural transformation and supports the retraining of displaced workers in cooperation with the private sector and its changing skill needs (Box 3). However, this re-training program is so far only financed by the public sector and is still small scale. 


\section{Box 3. Re-skilling trade-displaced workers}

The "Programa de Transformacion Productiva" and the reduction in import tariffs for computers and notebooks

In November 2016, Argentina announced a strong reduction of its tariffs on computers, notebooks and parts, which was implemented in February 2017. This measure increased competitive pressures on the domestic industry and decreased prices by $28 \%$ over a few months. Product quality improved due to the imports of higher quality inputs and domestic demand expanded. The move also benefitted the downstream software, IT and professional service sectors.

However, the increased import competition was a major challenge for domestic firms, which employed 4489 workers in November 2016. The "Programa de Transformación Productiva" played a key role in mitigating the negative employment effects of tariff reductions. Through re-training measures coordinated with six of the most important computer and notebook-producing firms, the workers were prepared for a re-orientation of the companies towards complementary service activities, e.g. technical support, sales and technical assessment. This ensured that none of these firms suffered major employment losses.

Since 2016, the "Programa de Transformación Productiva" has been dealing with 102 companies that work towards a technological upgrade of their production structure (providing financial support as well as training for the work force). It has also supported 1582 displaced workers with a special benefit of $50 \%$ of their last salary, labour market search assistance and retraining courses in collaboration with potential future employers. Future employers would also receive employment subsidies equivalent to the minimum wage over the first six month of the contract.

So far, of the 1582 workers included in the programme around 50\% have found a new job. This relatively low rate of re-employment is related to the low level of skills of the mostly older workers in the affected sectors, which indicates challenges related to skills. About nine million workers or around $50 \%$ of the total formal and informal workforce have not finished secondary education, and five million have not even finished primary education.

A unilateral tariff reduction would lead to moderate contractions and employment losses in textile and wearing apparel, the metal products, electronic equipment and the machinery and equipment industries (Table 6 and Annex Table A.5). For displaced workers, the cost of relocating to other sectors -where production and employment expand following tariff cuts- depends on whether the skill requirements differ between the new and the old job.

Previous OECD work has measured skill distances between occupations and sectors in terms of general cognitive and task-specific skills (Bechichi et al., 2018 ${ }_{[63]}$ ). This allows an assessment of the amount of retraining required for movements to expanding sectors (Table 9). This work suggests that many job changes that would likely occur in Argentina would be towards sectors that require a similar level of cognitive skills and would therefore not require an additional training in cognitive skills. An exception to this are workers currently employed in the textile, footwear and leather industry, which may require retraining equivalent to around half a year of schooling (or about 4 PIAAC skill scores) (Bechichi et al., 2018 ${ }_{[63]}$ ). As a large part of the workforce in the Argentinian textile, footwear and leather industries is informal and very low skilled, these estimates, which are 
based on industry averages across OECD and two non-OECD countries, might be too optimistic about the retraining needs for displaced workers.

Re-training of workers in the other three shrinking sectors would be limited mostly to joband task-specific skills, requiring close coordination with the private sector. The expanding sectors closest to the shrinking sectors in terms of skill distances are agriculture and other manufacturing sectors. Services sectors would also create more jobs in a more internationally integrated economy, but skill requirements for moving towards services would be higher (Table A.5,Table 6). As the analysis does not include detailed measures for the knowledge areas of jobs, the true re-training efforts required for job-changes might be underestimated (OECD, 2018 $\left.8_{[66]}\right)$.

Table 9. Retraining needs are mostly limited to task-specific skills

Based on skill distances between industries in terms of cognitive and task-specific skills and expected job reallocation patterns

\begin{tabular}{|c|c|c|}
\hline $\begin{array}{l}\text { Sectors with likely job } \\
\text { losses due to a tariff cut }\end{array}$ & $\begin{array}{l}\text { Three closest expanding sectors in } \\
\text { terms of skills }\end{array}$ & Type of skills needed for the transition \\
\hline \multirow[t]{3}{*}{$\begin{array}{l}\text { Textiles, textile products, } \\
\text { leather and footwear }\end{array}$} & $\begin{array}{l}\text { Agriculture, hunting, forestry and } \\
\text { fishing }\end{array}$ & $\begin{array}{l}\text { Self-organisation skills, accountancy and selling } \\
\text { skills }\end{array}$ \\
\hline & $\begin{array}{l}\text { Food products, beverages and } \\
\text { tobacco }\end{array}$ & $\begin{array}{l}\text { Cognitive skills: literacy, numeracy and problem } \\
\text { solving (distance equivalent to about half a school } \\
\text { year); } \\
\text { Management and communication skills }\end{array}$ \\
\hline & Construction & $\begin{array}{l}\text { Numeracy skills (distance equivalent to about half a } \\
\text { school year) } \\
\text { Accountancy and selling, management and } \\
\text { communication, self-organisation skills }\end{array}$ \\
\hline \multirow[t]{3}{*}{ Fabricated metal products } & $\begin{array}{l}\text { Agriculture, hunting, forestry and } \\
\text { fishing }\end{array}$ & $\begin{array}{l}\text { Self-organisation skills, accountancy and selling } \\
\text { skills }\end{array}$ \\
\hline & $\begin{array}{l}\text { Food products, beverages and } \\
\text { tobacco }\end{array}$ & Accountancy and selling skills \\
\hline & $\begin{array}{l}\text { Transport and Storage Services, Post } \\
\text { and Telecommunications }\end{array}$ & $\begin{array}{l}\text { Accountancy and selling, management and } \\
\text { communication skills, readiness to learn }\end{array}$ \\
\hline \multirow[t]{3}{*}{$\begin{array}{l}\text { Electrical and Optical } \\
\text { Equipment }\end{array}$} & $\begin{array}{l}\text { Agriculture, hunting, forestry and } \\
\text { fishing }\end{array}$ & $\begin{array}{l}\text { Self-organisation skills, accountancy and selling } \\
\text { skills }\end{array}$ \\
\hline & $\begin{array}{l}\text { Food products, beverages and } \\
\text { tobacco }\end{array}$ & No major retraining needs expected \\
\hline & $\begin{array}{l}\text { Chemicals and non-metallic mineral } \\
\text { products }\end{array}$ & No major retraining needs expected \\
\hline \multirow[t]{3}{*}{ Machinery and equipment } & $\begin{array}{l}\text { Food products, beverages and } \\
\text { tobacco }\end{array}$ & No major retraining needs expected \\
\hline & $\begin{array}{l}\text { Wood, paper, paper products, printing } \\
\text { and publishing }\end{array}$ & Accountancy and selling skills, readiness to learn \\
\hline & $\begin{array}{l}\text { Chemicals and non-metallic mineral } \\
\text { products }\end{array}$ & No major retraining needs expected \\
\hline
\end{tabular}

Note: The four sectors in the left column are the sectors with expected job losses from a cut in tariffs to the lowest levels of G20 countries (see Table 6 and Annex Table A.5). The middle column shows the three job-creating sectors with the lowest skill distance in terms of cognitive and task-specific skills. Measures for cognitive and task-based skills are based on the OECD Survey of Adult Skills (PIAAC) (Grundke et al., 2017[67]). Cognitive skills include literacy, numeracy and problem solving in technology rich environments. Task-specific skills include ICT skills, managing and communication, accountancy and selling, self-organisation, advanced numeracy as well as readiness to learn. The average skill distances by sector are computed for the whole set of 31 OECD and Non-OECD countries included in PIAAC (Bechichi et al., 2018[63] ). The skill distances may underestimate the true re-training effort required for job changes as skill indicators cannot measure all dimensions of skills and knowledge areas required for jobs. Source: OECD calculations based on skill indicators constructed using the OECD Survey of Adult Skills (PIAAC) (Bechichi et al., 2018[63]; Grundke et al., 2017 ${ }_{[67]}$ ). 
The above analysis uses information on the skill requirements of occupations and sectors from the OECD Survey of Adult Skills (PIAAC). As Argentina does not participate in the PIAAC survey, cross-country averages have been used instead. The analysis could be further improved if Argentina were to participate in the next round of this OECD survey.

Industries that are exposed to an increasing penetration of digital technologies require workers to combine good cognitive skills with an increasing ability to self-organise, to work in teams across interdisciplinary and cultural borders and to communicate using new ICT technologies (Grundke et al., 2018 ${ }_{[68]}$ ). Especially the booming IT, software and professional business services sectors, will require a large amount of workers that can master the challenges of the digital transformation. To address these needs the government has launched an ambitious plan to educate 100000 new software programmers, 10000 software professionals and 1000 software entrepreneurs in 4 years (Plan 111 mil). The plan was closely coordinated with the Argentinian software business association and is adapted to the skill needs of the private sector (recently a new plan to educate 500000 by 2030 was presented). Such cooperation with the private sector could be a model for other sectors, where firms have difficulties to find workers with the right skill mix they need (Figure 28). However, as the technological frontier is shifting fast in many sectors, the provision of continuous adult training is also key to master the challenges of the digital transformation (OECD, 2016[69]).

Figure 28. Firms face difficulties finding the skills they need

Share of firms with difficulties finding qualified staff, 2017

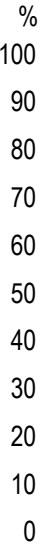

Source: Manpower Group (2018).

Vocational education and training (VET) remains underutilised, below average levels observed in OECD countries, Chile and Mexico (Figure 29), and is of low quality. At the same time, survey results suggest that employers are finding it particularly hard to find technicians, skilled tradespeople and engineers (INET, 2016 $\left.6_{[70]}\right)$. Thus, expanding and enhancing the effectiveness of VET can be particularly useful to address these skill mismatches and to raise workers employability. This would also benefit firms, as equipping workers with the right skills goes along with higher productivity. Additional analysis conducted for this paper finds that formal training programmes for workers are associated with $1.9 \%$ higher total factor productivity of Argentinian firms (Annex A.2). In addition, 
offering VET as a less academic option in secondary education can reduce the high-dropout rates in secondary education.

International experience suggests that workplace training and involving employers in the design and delivery of the training are key elements for a successful development of VET (O'Connell et al., 2017 $7_{[71]}$ ). Currently training institutions are the dominant players of the VET system without much engagement of the private sector, and there is little coordination between the large numbers of regional institutions. Increasing coordination between the different training institutions across and within provinces and giving employers a more central role, both in the design of courses and in the delivery of workplace training, would bring the VET system closer to international standards. A recently established programme for young adults (18-24 years) who return to school and in parallel acquire professional training is a first step in this direction.

As in many OECD countries, there is also scope for a better alignment of tertiary education curriculums to the type of occupations prevailing in the labour market (OECD, 2017 [72]). Skill shortages are particularly concentrated among engineers and technical degrees and reflect a tertiary education system that produces too few graduates in science, technology, engineering or mathematics (Figure 29) (OECD, 2016 $[69])$. To facilitate the alignment of curriculums to the skills required in different occupations, the authorities should consider an update of the outdated Argentinian classification of occupational titles in a joint multistakeholder effort including the private sector and worker organisations.

Figure 29. Few students follow technical courses and careers
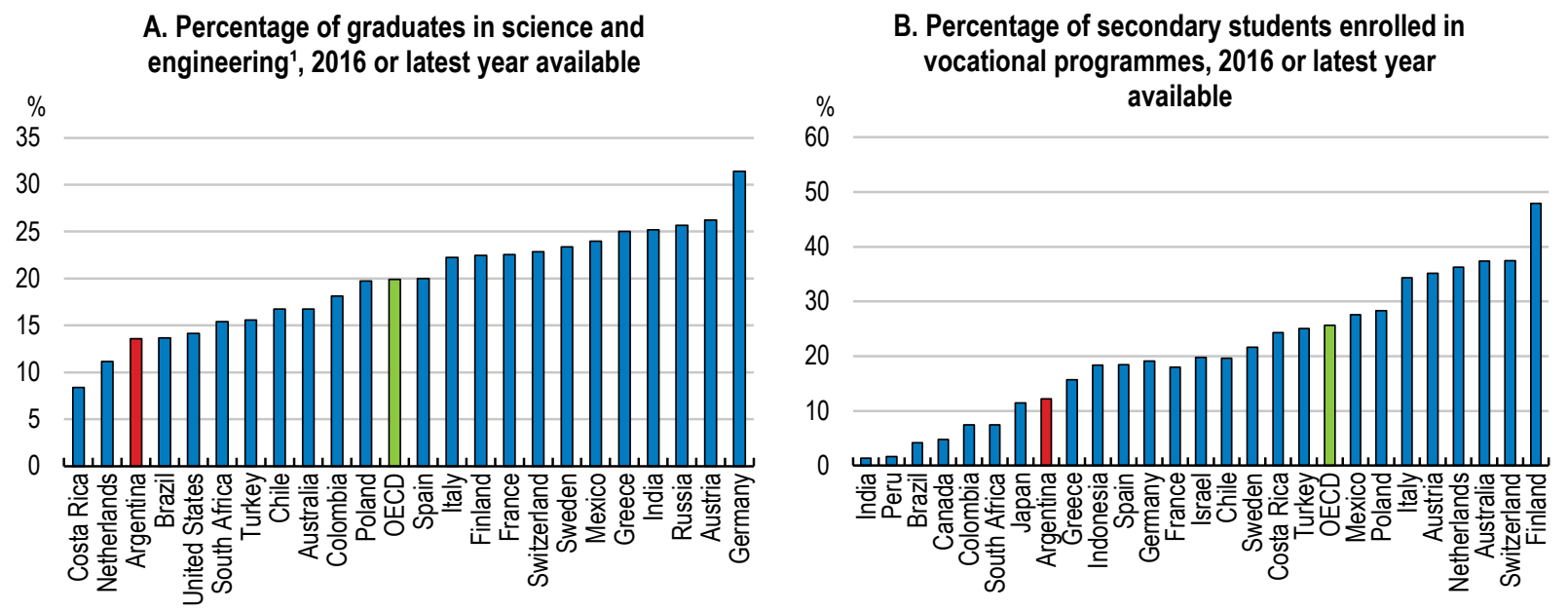

1. This includes all the tertiary graduates in the fields of Engineering, Manufacturing, Construction, Natural Sciences, Mathematics and Statistics. Data refer to the latest available year.

Source: World Bank World Development Indicators database; OECD Education at a Glance database; and UNESCO Education database.

\section{StatLink त्गाज् http://dx.doi.org/10.1787/888933942809}

A well-functioning social safety net can protect incomes during temporary unemployment spells. Argentina has well-targeted family benefits that support low-income families with children. While these have a significant impact for relieving poverty among families with children, they are insufficient to protect adults against the income losses from temporary income spells. 
Unemployment benefits have a limited coverage due to stringent eligibility conditions, with only approximately one in ten unemployed persons receiving unemployment benefits. Benefit levels are capped at EUR 90 per month, around $40 \%$ of the minimum wage, and are paid for up to 12 months, or 18 months for those aged above 45 . A more potent protection against temporary income losses from dismissals are high severance payments. However, these create disincentives for formal hiring, as the costs of dismissal can be high for employers. Moreover, there is discretionary room for the judiciary to determine the magnitude of these severance payments in each single case, creating uncertainty for employers.

Current reform plans include replacing the severance payment regime by an unemployment insurance system with individual accounts, to which both employers and employees would contribute over time, similar to the one currently used in the construction sector. Chile, for example, has established such a system. This would reduce the financial burden of dismissals as employer contributions are paid over time and could lead to lower disincentives for formal hiring, if only by reducing uncertainty. If account balances could be carried over to a new job, such a system would be an effective way to protect people rather than protecting individual work relationships.

The currently $30 \%$ of the workforce that is in informal employment lacks any income support in case of job loss. Therefore, improving incentives for formal employment, both by reducing the costs of formalisation and through more enforcement, is essential for reducing the social impact of future job reallocations.

\section{Improving the functioning of product markets}

In the context of opening up to foreign competition, it is also important to eliminate policy distortions caused by domestic regulations, to allow new firms to enter and thrive on the domestic market before they potentially export. Regulations of product markets serve a variety of legitimate objectives, but if ill-designed they can impose unnecessary restrictions on competition. Competition, which induces firms to become efficient or exit, has been traditionally weak and poor domestic policies have held back competitiveness of producers, thus impeding them from exploiting their full productivity potential. Regulations can also have downstream effects on non-regulated sectors of the economy that use the output of the regulated sectors as intermediate inputs (Arnold et al., 2016 ${ }_{[73]}$ ). For example, inadequate regulation of the electricity sector will have effects on other sectors such as manufacturing where electricity is an important input.

The OECD Product Market Regulation (PMR) indicator and its sub-indicators measure the competition-restrictiveness of product market regulations across a wide range of countries. A recent update of the indicator suggests that Argentina tops the list of countries with respect to the restrictiveness of product market regulations (Figure 30). Improving product market regulation fosters competition, which in turn can raise productivity and hence the ability of firms to pay higher wages and their probability to export (Bernard, Van Beveren and Vandenbussche, 2014 $[74]$. By reducing entry barriers, product market reforms can facilitate the emergence of new firms, boosting investment and job creation relatively fast (OECD, 2016 $\left.6_{[75]}\right)$. 
Figure 30. There is room to reduce the restrictiveness of product market regulations

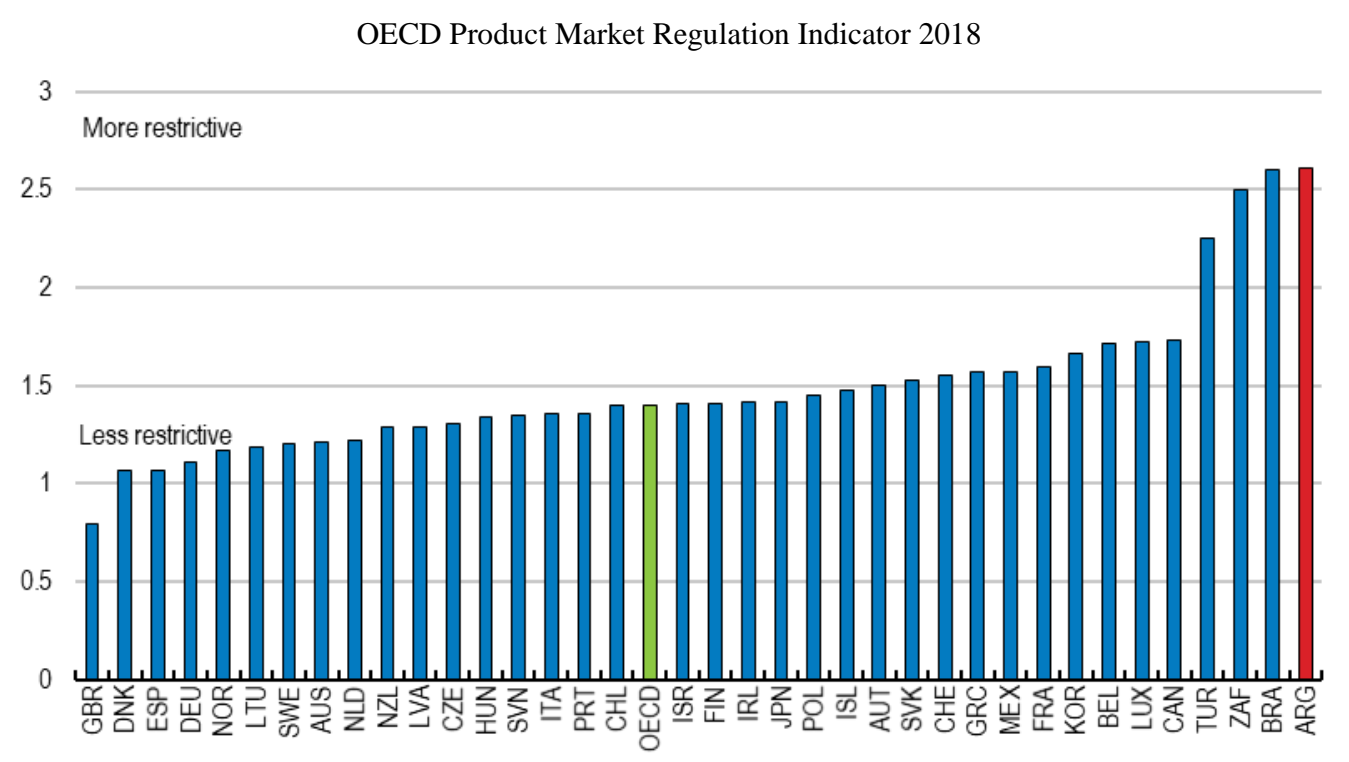

Note: The OECD indicators of product market regulation are synthetic indicators that summarise a wide array of different regulatory provisions on product markets across countries, with a focus on the degree to which these regulations restrict competition. They are expressed on a scale from 0 (least restrictive) to 6 (most restrictive). Data are refer to 2018. The OECD average shown does not include the United States.

Source: OECD Product Market Regulation (PMR) database.

Argentina still has the highest barriers to domestic entry in Latin America, well above those in Brazil, Mexico or Chile. This is mainly due to high entry barriers in network and services sectors (Figure 31). Regarding administrative burdens for start-ups, Argentina has considerably improved and moved five ranks upward in the cross-country comparison. The new entrepreneurship law (ley de emprendedores) has been an important step into the right direction, as it facilitates firms' start-up by creating a new type of firm, which can be set up in one day. It also comprises setting-up single contact points for issuing or accepting notifications as well as online one stop-shop services, including filing tax declarations online.

Argentina has also considerably improved the procedures for design and assessment of regulation. The complexity of regulatory procedures has been reduced, especially those related to obtaining licences and permits. Regarding the involvement of stakeholders in the regulatory process, Argentina is close to the median in the sample. However, the overall index for simplification and evaluation of regulation shows Argentina at a low rank, because the assessment of regulations regarding their impact on competition leaves still much room for improvement (Figure 31). It should be a priority to complement the recent advances in competition enforcement, where the establishment of a new competition authority with greater personal and financial independence and an improved legal framework have been major steps, with a thorough evaluation of the impact on competition of existing and future regulations. The OECD's Competition Assessment Toolkit (OECD, $\left.2017_{[76]}\right)$ can provide guidance not only for identifying but also for revising policies that unduly restrict competition. It also provides interesting examples and case studies from Greece, Mexico, Portugal and Romania.

Argentina still performs weakly on the indicator on state involvement in business operations, owing to price controls, as well as command and control regulation that 
interfere in the functioning of markets (Figure 31). For example, price controls remain in place in the retail and the energy sectors and professional services face much stricter regulations than in the average OECD country. The government should continue moving away from coercive and towards more incentive-based regulation.

However, the new regulations of public procurement have been successful (Figure 31). Public procurement of goods and services as well as for public works is organised in transparent public tenders that do not discriminate much more against foreign suppliers than the average OECD country. For example, the elimination of intermediaries for the public purchase of medicaments will likely increase competition among suppliers and lead to significant price reductions. However, recent changes to the law on public procurement introduce local content rules of $20 \%$ favouring Argentinian SMEs and improve their chances in public tenders leading to a stronger discrimination against foreign suppliers. The current economic downturn with high interest rates and the recent spikes in utility prices might justify some additional support for SMEs in the short run. However, this support should be temporary as it is likely to raise costs for the government and shields SMEs from the positive effects of domestic and foreign competition.

Figure 31. Product market regulations could allow more room for competition

OECD Product Market Regulation Indicator 2018
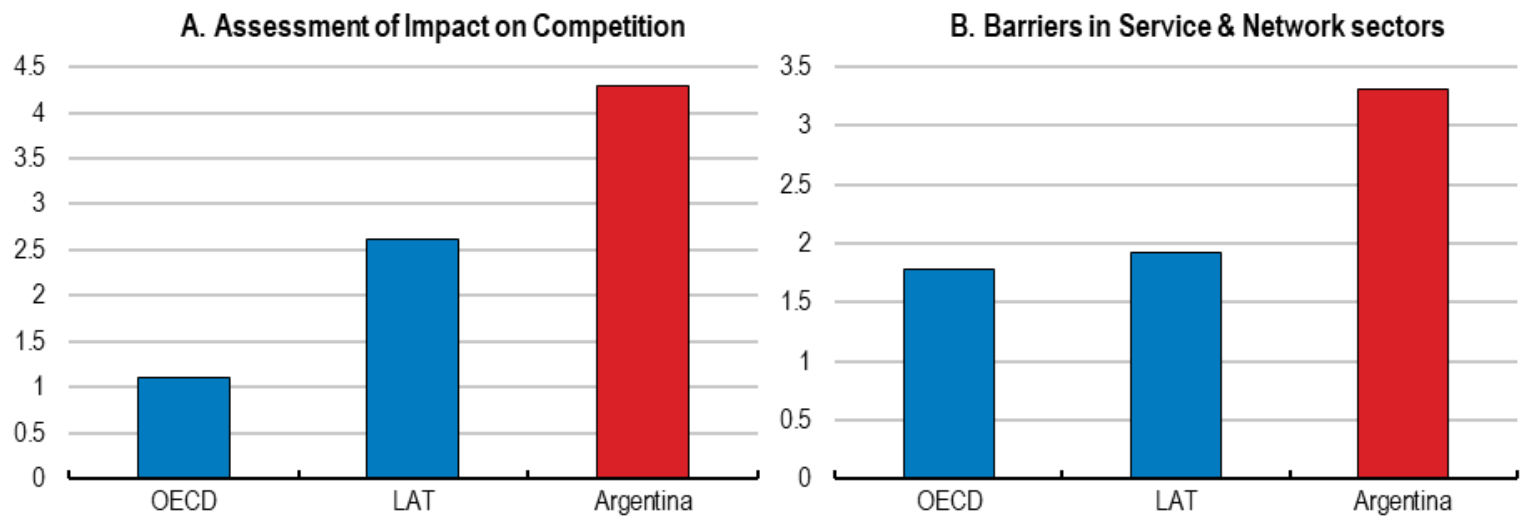

C. Command \& control regulation
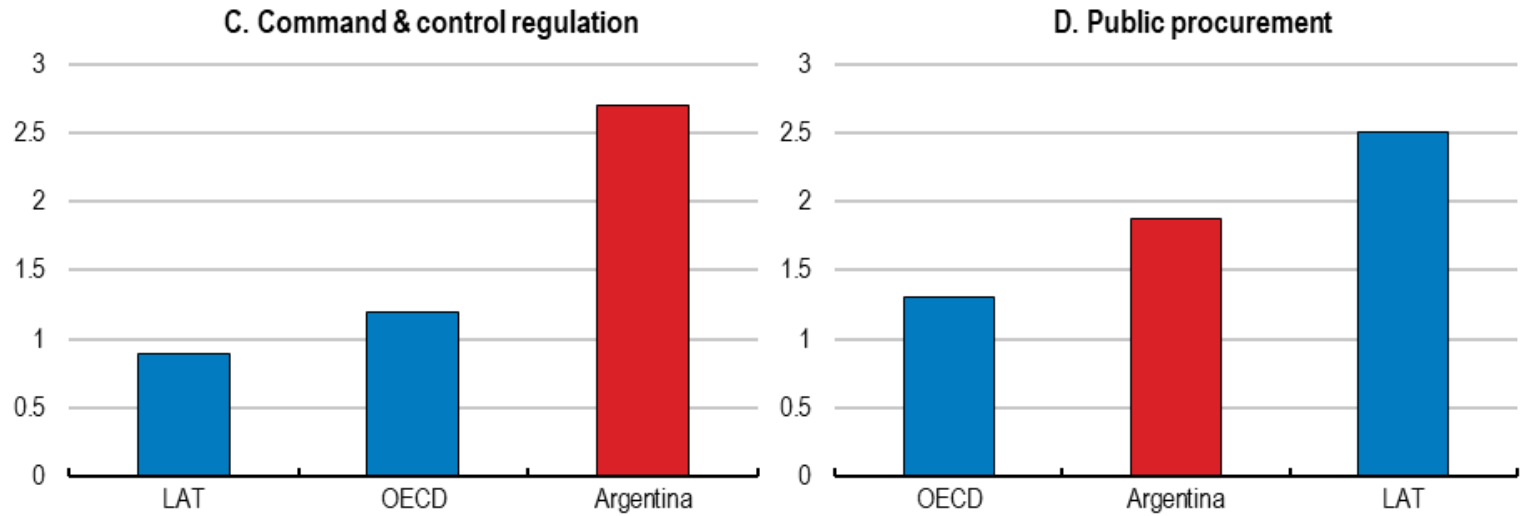

Note: LAT is the average of Brazil, Chile and Mexico. The OECD average shown does not include the United States. Data are for 2018.

Source: OECD Product Market Regulation (PMR) database. 
Furthermore, the existing regulatory framework still fragments the domestic market, as regional and local authorities often impose extra requirements on companies from other parts of the country. This results in weak competition at the local level (Figure 32), contributing to a loss of competitiveness abroad and higher prices domestically. By reducing the scale of production, these barriers also hamper productivity and real wages. At the national level, a comprehensive initiative of the Argentinian government aims at strengthening the wider use of online tools and sharing of information across government agencies to reduce administrative burden and identify regulations that act as impediments to entrepreneurship. Argentina would strongly benefit from including regional and local governments into this initiative, and assess the impact of regulations on domestic and foreign competition. Recent coordination initiatives to promote such dialogue between different levels of governments in federal councils are so far voluntarily and should be made obligatory for provinces and municipalities (OECD, 2019 $\left.9_{[77]}\right)$.

Figure 32. Local competition is low

Intensity of local competition, 2017-18

1-7 (best)

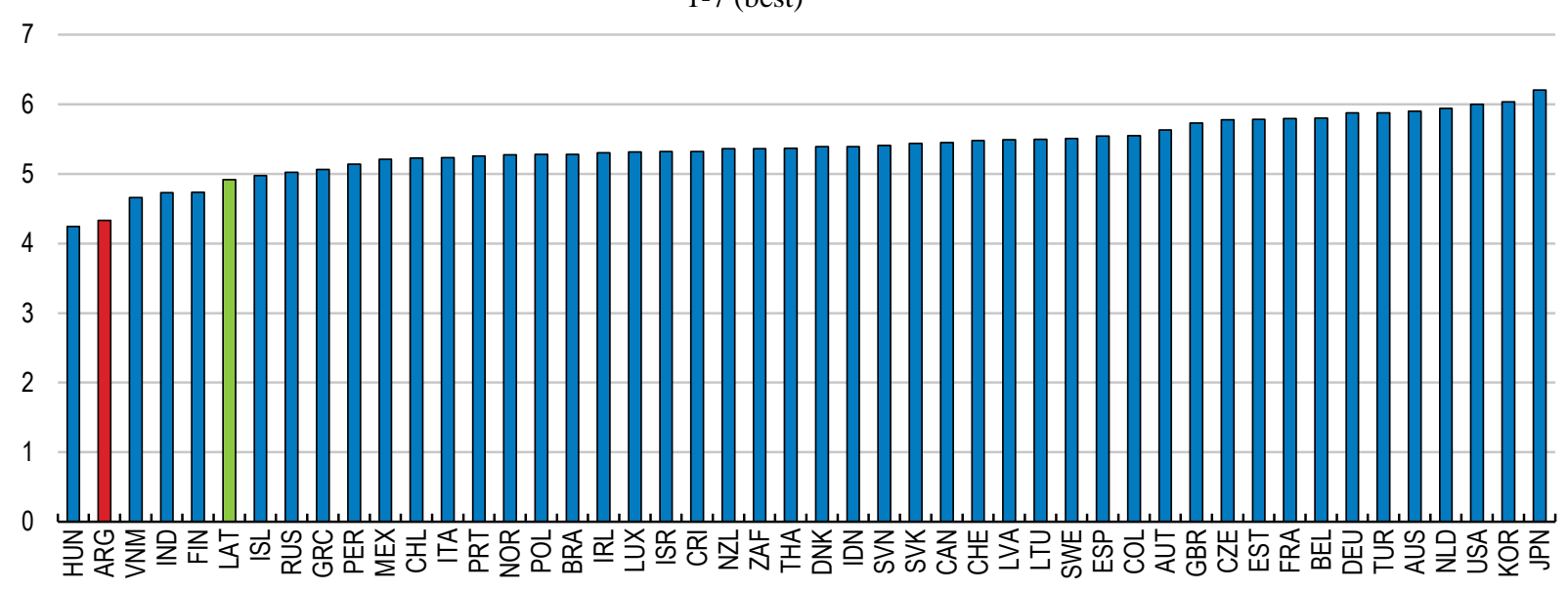

Source: World Economic Forum Global Competitiveness Index Dataset.

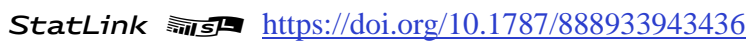

Similar programmes have been set up in some OECD countries such as Australia, Canada and Spain. In Spain, all legal texts enacted by local, regional and central governments are checked for inconsistencies. If they are found to create internal barriers to trade, they need to be amended in the subsequent six months (González Pandiella, 2014 ${ }_{[78]}$ ). The Council of Australian Governments, established in 1992, has focused on in-depth harmonisation of legislation, standards and regulations among the states. Canada also faces challenges with internal barriers to trade and investment arising from overlapping federal, provincial and territorial regulatory responsibilities regarding many economic policy areas. It established the so-called Agreement on Internal Trade in 1995, an intergovernmental trade agreement according to which parties commit to a set of general rules to prevent governments from establishing new trade barriers and to reduce existing ones.

High barriers to entrepreneurship, and in particularly those deterring entry, can hamper significantly the creation of new firms. In turn, the absence of the disciplining effect of competition from new entrants, firms tend to grow less, remain small and be less productive (Klapper et al., 2006 ${ }_{[79]}$ ). Some of these features are noticeable in Argentina's 
manufacturing sector, characterised by a small number of young firms (Figure 33). The average Argentinian firm is 27 years old, well above average age observed in Latin America (21 years) and OECD economies (17 years) (according to the World Bank Enterprise Survey). OECD work based on cross-country firm level data indicates that young firms create more jobs (Criscuolo, Gal and Menon, 2014 ${ }_{[29]}$ ). Over the past decade and across all countries analysed, $42 \%$ of all jobs were created by enterprises less than 5 years old. In Argentina, only $6 \%$ of firms are younger than 5 years.

Figure 33. There are few young firms in Argentina

Percentage of firms by age group for the year 2017 (in \%)

30

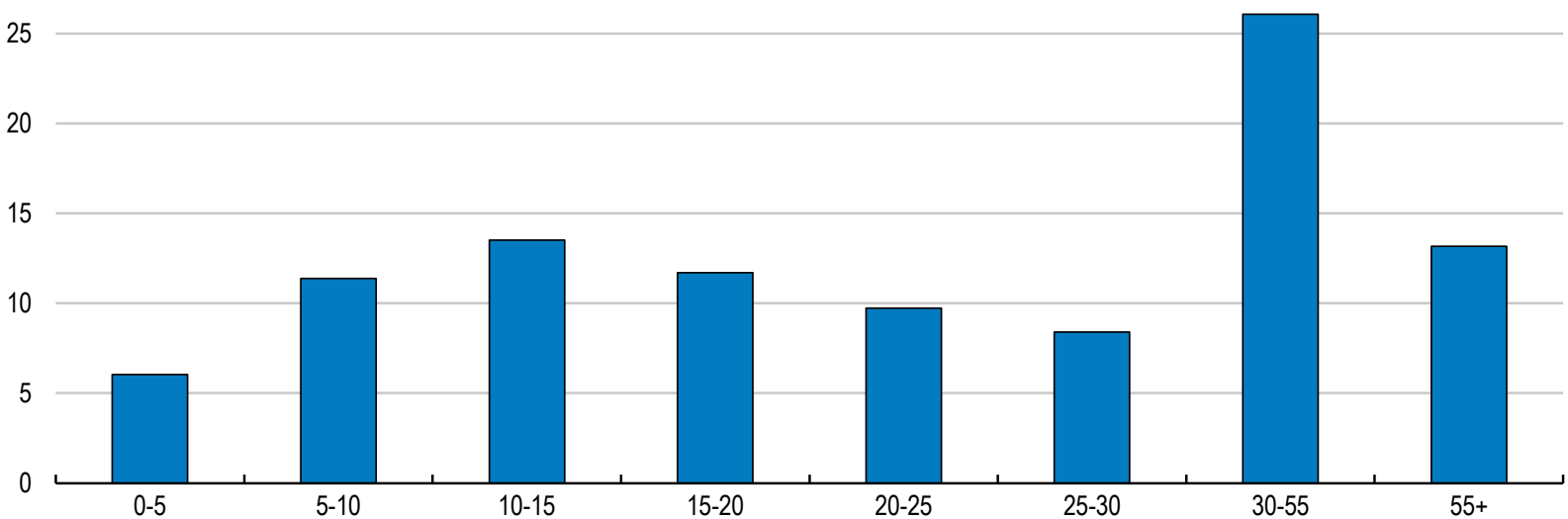

Source: OECD calculations based on the World Bank Enterprise Survey 2017.

StatLink त्गा5 https://doi.org/10.1787/888933943455

Effective insolvency regimes can also play an important role to foster entrepreneurship and productivity (Adalet McGowan, Andrews and Millot, 2017[80]). Argentina's insolvency procedures are in line with the Latin America average but are less efficient than in some regional peers such as Colombia or Chile, or than those found in OECD countries (World Bank, 2018 $[81])$. Improving insolvency procedures, by making them more agile and less costly, would boost entrepreneurship by providing second chance opportunities to entrepreneurs. They can also help to boost productivity and competition by increasing firm creation (Cumming, 2012 ${ }_{[82]}$ ) and by facilitating the reallocation of capital and financing to new young firms boosting job-creation.

Some measures associated with industrial policies can also curb domestic competition. Industrial policies have had a long history of protecting and subsidising specific industries in Argentina. Such policies can easily stand in the way of structural transformation. By favouring established incumbents over entrants or drawing resources into specific sectors, they often act as impediments to the creation of new innovative young firms, which disproportionally contribute to productivity growth and job creation (Criscuolo, Gal and Menon, 2014 [29]; Eric Bartelsman et al., 2013[83]).

Rather than betting on specific sectors and adding to existing distortions, cost-efficient and effective industrial policies can help to reduce information and coordination problems, e.g. by providing detailed sector specific information on export markets provided by successful 
exporting firms (Artopoulos, Friel and Hallak, 2013 ${ }_{[35]}$ ). In addition, horizontal structural reforms that improve the business climate without favouring specific sectors, such as tax reforms or improvements in infrastructure, can help the transition towards a more integrated economy without curbing competition.

A tax reform decided in 2017 will reduce some existing distortions and lower the overall tax burden on businesses over a period of 5 years, to stimulate investment and formal employment. For businesses, the reform focuses on reducing statutory corporate income tax rates, while raising the taxation of distributed profits and on the gradual phase-out of the most distortive taxes such as the provincial turnover tax. This tax has a cascading effect and creates an artificial incentive for vertical integration, as there is no deduction for the tax paid at earlier production stages (as there would be in a VAT). It hurts competitiveness and acts as an interprovincial tariff barrier, as different tax rates are applied depending on the domestic origin of goods. As part of the accelerated fiscal adjustment, the gradual phase-out schedule of this tax has been revised and partly postponed upon request from the provinces, for which this tax is a major source of revenues. In the medium run, it will be important to continue the process of phasing out the turnover tax.

A financial transaction tax on every transaction in checking and saving accounts creates incentives to settle payments in cash, acting as a barrier for financial inclusion and formalisation. Plans to make this tax fully deductible from corporate income taxes have also been postponed in light of its significant revenues amounting to 1\% of GDP. Looking ahead, the financial transaction tax should be abolished once the fiscal situation permits it. Broadening the tax base, for example in the area of VAT or personal income taxes, would create scope for lowering tax rates and accelerate the phase-out of particularly distortive taxes (see chapter "Key policy insights").

\section{Strengthening innovation}

Innovation and investment in knowledge-based capital are important engines of growth and productivity (Foster et al., 2018 ${ }_{[84]}$ ). Based on standard innovation indicators, such as patents applications, Argentina's performance is relatively low, below regional peers such as Chile and OECD standards. This general weak performance contrasts with remarkable success cases. For example, Argentina is a top performer in the aerospace sector, being at the vanguard in the satellite industry and in drone development. The agriculture sector is also at the innovation frontier in terms of farming techniques and use of biotechnology with INTA (Instituto Nacional de Tecnología Agropecuaria, National Agricultural Technology Institute) playing a key role in generating and promoting the diffusion of technologies (OECD, 2019[85]). These examples are suggestive of the high potential to become a top innovation performer.

Total spending on research and innovation is relatively low, amounting to $0.6 \%$ of GDP, which is about half of Brazil and one fourth of the OECD average of $2.4 \%$. The bulk of funds come from public sources, $96 \%$ of the total in 2011-2015, compared to only $3.5 \%$ from the private sector and $0.5 \%$ from international sources. In terms of implementation, decentralised public institutions such as the Consejo Nacional de Investigaciones Científicas y Técnicas (CONICET), the Instituto Nacional de Technología Industrial (INTI), or the Instituto Nacional de Tecnología Agropecuaria (INTA) represent almost 50\% of the total spending, while public universities represent around 30\% (MINCYT, 2015 [86]). Expenditure on personnel represented $70 \%$ of total expenditure on R\&D activities. Almost half of all resources were directed to applied research, compared to $40 \%$ for basic research. 
"Agricultural production and technology" represents the largest reported focus area for public R\&D investments in 2015 (Figure 34). Agriculture-related R\&D objectives are also included in "non-oriented research" (basic research), "control and protection of the environment" and "land exploration and exploitation". The share of total investments going into research related to industrial production and technology is relatively low with $13 \%$. To support the structural transformation of the economy, the government might evaluate the possibility of increasing public funds for research and development (possibly through reallocation of resources) to further support innovation clusters for promising industries and services, which are already close to the global technology frontier. These innovation clusters can have significant technological and knowledge spill-overs to the private sector (Baer, 2018 ${ }_{[87]}$; Cabrer-Borrás and Serrano-Domingo, 2007 [88]).

Figure 34. Public R\&D investments by objective, 2015

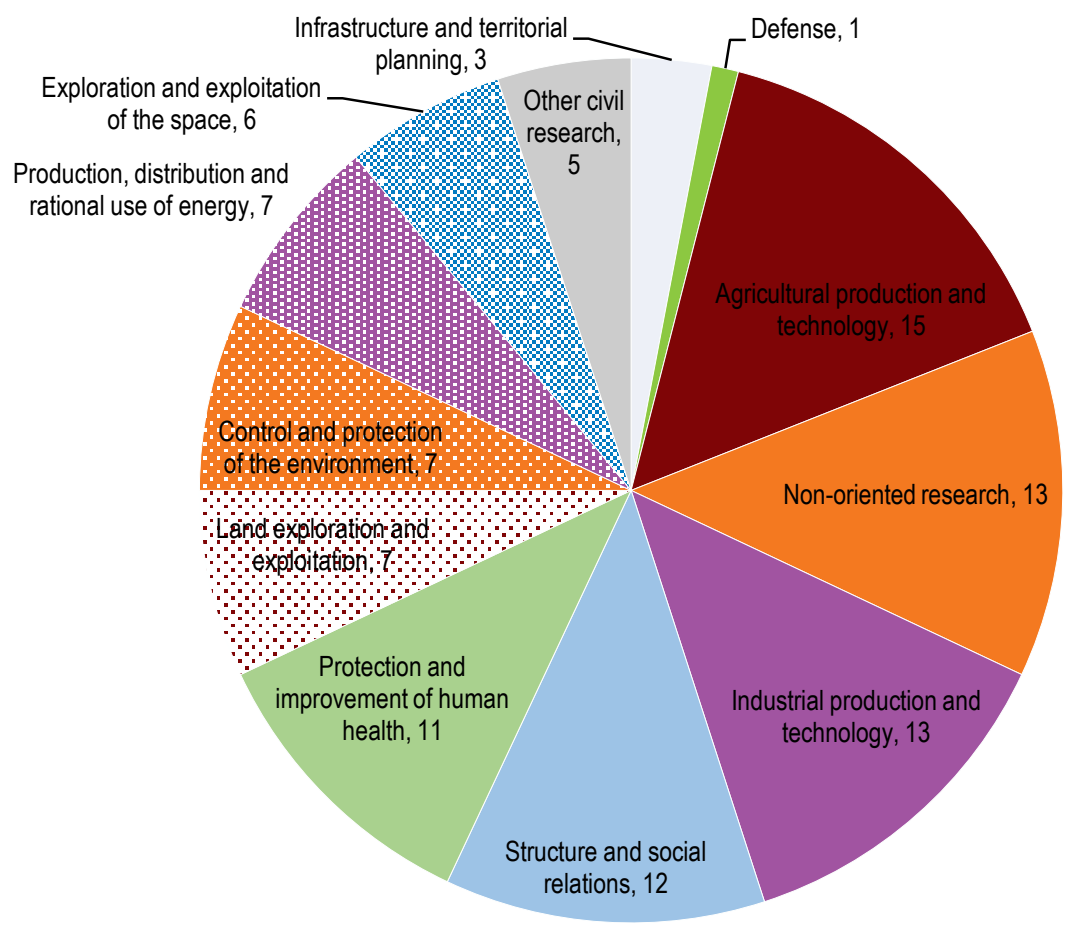

Source: (OECD, 2019[85]) based on (MINCYT, 2015[86])

StatLink तiाst https://doi.org/10.1787/888933943474

However, the main bottleneck in terms of expenditure for research and development is the private sector, which spends only $0.1 \%$ of GDP for research and development activities, versus $0.5 \%$ in Brazil or $1.1 \%$ in the average OECD country (Figure 35). Acknowledging that innovation is a key pillar for the new economic model, the authorities aim at improving incentives for raising business investment in research and development, but also plan to increase public expenditures for R\&D. However, recent macro-economic turbulence and the necessary fiscal adjustment will pose limits on reaching this goal, in particular for public investments in R\&D. 
Figure 35. Business innovation is low

Business enterprise expenditure in research and development, 2016 or latest year available

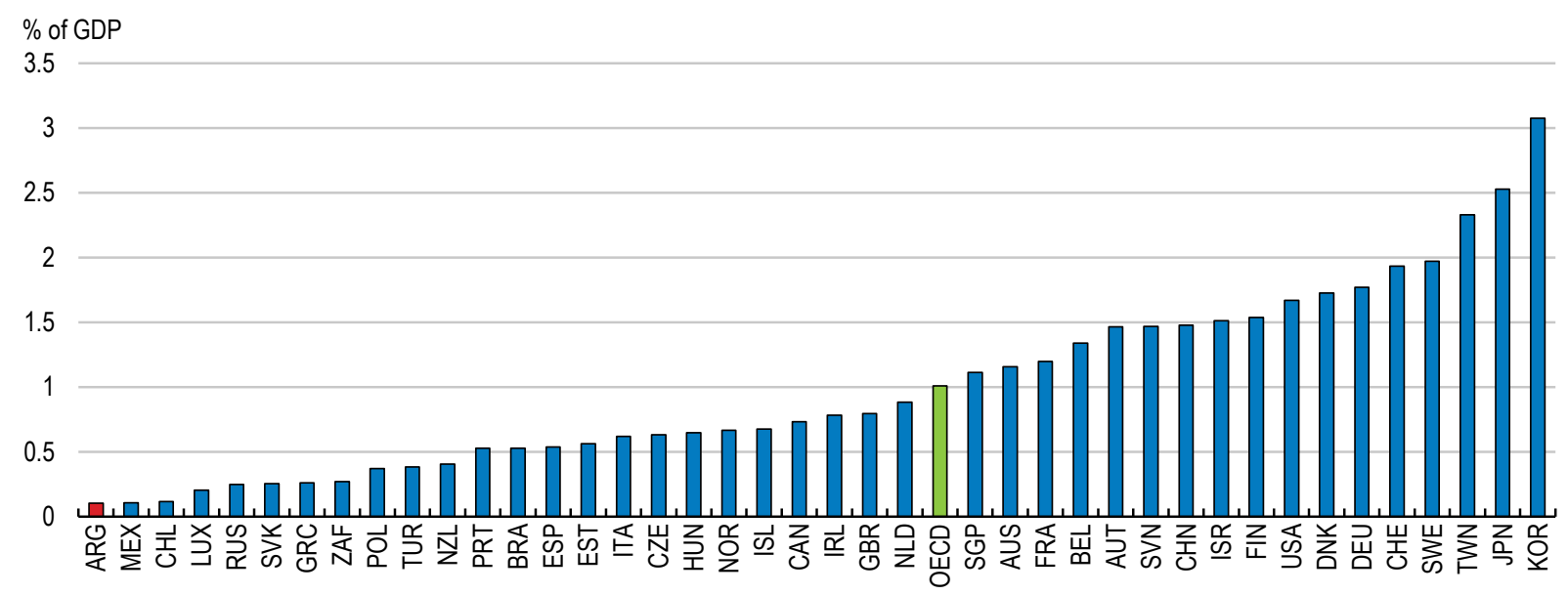

Source: OECD Research and Development Statistics database.

StatLink तiाs https://doi.org/10.1787/888933943493

Firm-level analysis conducted for this report emphasises the need to raise private innovation activities. An increase in expenditure for research and development by one million Pesos is associated with a $1.6 \%$ higher total factor productivity of Argentinian firms (Annex A.2). Moreover, firms using technology licensed by a foreign company have a 2.3\% higher total factor productivity, indicating the importance of reducing import barriers to facilitate technology diffusion. Providing access to digital technologies is also crucial, as firms that have a website show a $2.4 \%$ higher total factor productivity.

However, the lack of competitive pressure on product markets curtails incentives for engaging in innovation activities and adopting new technologies and practices. Entry or the threat of entry have been found to stimulate innovation by incumbent firms (Aghion et al., $\left.2005_{[89]}\right)$. When the incentive to get a competitive edge over others is missing because competitive pressures are low, firms do not consider innovation a priority. Moreover, where competition does not drive less efficient firms out of the market to free their resources, much of the public support for research and development may be absorbed in prices and wages rather than in the quantity of R\&D (Acemoglu et al., 2013 ${ }_{[90]}$ ). Therefore, progress to strengthen domestic and foreign competition, as discussed above, would likely lead to more innovation (Bustos, 2011 [91]).

There is also room to improve specific innovation policies. A key tool to foster innovation in firms is the R\&D tax credit, which aims at alleviating difficulties faced by firms to fully appropriate the returns to their $R \& D$ investment and to find external finance, in particular for small or young firms (Appelt et al., 2016 $6_{[92]}$ ). Argentina has an R\&D tax credit based on a competitive allocation system with a budget of $0.002 \%$ of GDP. The tax credit is applicable against tax obligations in the provincial gross turnover tax, which is an unusual design that puts young innovative firms at a disadvantage. Instead, in other countries, R\&D tax credits can reduce corporate income tax liabilities, in some cases even with the possibility of refunds or extended loss carry-forward provisions. More innovative start-ups, focused on developing new products and technologies, usually have little sales initially, as the first commercialised forms of new innovations tend to fail (Agarwal and Bayus, 
$\left.2002_{[93]}\right)$. Hence, the more innovative young firms are less likely to benefit from the tax credit under its current design. International evidence shows that to support these type of firms, the tax credit should include provisions such as the possibility to be converted into cash refunds or into reductions in social security and payroll taxes or include carry forward provisions (Appelt et al., 2016 $6_{[92]}$ ).

Moving in that direction would optimise the support given to young and innovative firms, although it would reduce public revenues. Thus, the competitive allocation system of the tax credit together with the limited fiscal space of the government introduce a strong degree of uncertainty about the eventual availability of the credit, and thus the tax credit does not significantly alleviate the difficulties that firms face to finance innovation activities.

Strengthening the protection of intellectual property rights could also help Argentina to attract more foreign direct investment in some knowledge-intensive areas, such as biotechnology, for which it may have a natural advantage. According to some of its main trading partners, Argentina has considerable scope to strengthen its intellectual property rights protection, including by broadening its patentability criteria (European Commission, 2018[94]; USTR, 2018 ${ }_{[95]}$ ). Existing international measures of intellectual property rights protection suggest that Argentina ranks below all OECD countries in this area (LevyCarciente and Montanari, 2018 $\left.{ }_{[96]}\right)$. Empirical evidence suggests that where rights are strong, foreign companies are not only more likely to invest but are also more willing to share technologies with local partners and more likely to engage in local research and development $\left(\mathrm{OECD}, 2015_{[97]}\right)$. Intellectual property rights also provide an incentive to invest in research and development, fostering the creation of innovative products and processes and they give their holders the confidence to share new technologies through joint ventures and licensing agreements. In this way, successful innovations can be diffused within and across economies, bringing higher productivity and growth. 


\section{Box 4. Recommendations to foster integration into the world economy}

\section{Key recommendations}

- Reduce tariffs and non-tariff barriers, starting with capital goods and intermediate inputs.

- Bolster adult training programmes and vocational education and training (VET) to ease the transition.

- Extend the unemployment insurance scheme with individual accounts currently used in the construction sector economy-wide, while reducing severance payments.

- Reduce domestic regulatory barriers to entrepreneurship and market entry, including at the level of provincial and local governments.

\section{Other recommendations}

- Take an active role in seeking more trade agreements between MERCOSUR and large markets. Take unilateral measures to reduce trade barriers, especially nonautomatic import licenses.

- Further reduce administrative requirements for importing and exporting, including by fully implementing the online one-stop mechanism nationwide.

- Implement mandatory competition assessments of existing and future regulations.

- Continue improving the tax system by letting export taxes expire as planned in 2020 and phasing out provincial turnover taxes and financial transaction taxes.

- Simplify insolvency procedures and increase their effectiveness to reduce costs for entrepreneurs.

- Improve the quality of lifelong learning institutions for adults through better coordination between the different existing institutions across and within provinces.

- Promote a multi-stakeholder dialogue to anticipate skills needs, update the current classification of occupational titles and identify skills mismatches and shortages.

- Consider participating in the OECD Survey of Adult Skills (PIAAC) to inform education and training policies on skill needs.

- Improve the certification system for work competences to enhance employability, in particular for informal workers. 


\section{References}

Acemoglu, D. et al. (2013), "Innovation, Reallocation and Growth", NBER Working Paper

Series, No. 18993, NBER, https://economics.mit.edu/files/15064 (accessed on

8 October 2018).

Adalet McGowan, M., D. Andrews and V. Millot (2017), "Insolvency Regimes, Technology Diffusion and Productivity Growth : Evidence from Firms in OECD Countries", OECD Economics Department Working Papers, No. 1425, OECD Publishing, Paris, http://dx.doi.org/10.1787/36600267-en.

Agarwal, R. and B. Bayus (2002), "The Market Evolution and Sales Takeoff of Product Innovations", Management Science, Vol. 48/8, pp. 1024-1041, https://www.jstor.org/stable/pdf/822673.pdf?refreqid=excelsior\%3A0a1baef697eeb5c87d2e4 0bd677ff0b4 (accessed on 8 October 2018).

Aghion, P. et al. (2005), "Competition and Innovation: an Inverted-U Relationship", The Quarterly Journal of Economics, Vol. 120/2, pp. 701-728, http://dx.doi.org/10.1093/qje/120.2.701.

Amiti, M. and A. Khandelwal (2013), "Import Competition and Quality Upgrading", The Review of Economics and Statistics, Vol. 95/2, pp. 476-490, https://www.mitpressjournals.org/doi/pdf/10.1162/REST_a_00271 (accessed on 22 September 2018).

Amiti, M. and J. Konings (2007), "Trade Liberalization, Intermediate Inputs, and Productivity: Evidence from Indonesia", American Economic Review, Vol. 97/5, pp. 1611-1638, http://dx.doi.org/10.1257/aer.97.5.1611.

Amiti, M., S. Redding and D. Weinstein (2019), "The Impact of the 2018 Trade War on U.S. Prices and Welfare", National Bureau of Economic Research, Cambridge, MA, http://dx.doi.org/10.3386/w25672.

Appelt, S. et al. (2016), "R\&D Tax Incentives: Evidence on design, incidence and impacts", OECD Science, Technology and Industry Policy Papers, No. 32, OECD Publishing, Paris, http://dx.doi.org/10.1787/5jlr8fldqk7j-en.

Arnold, J. et al. (2016), "Services Reform and Manufacturing Performance: Evidence from India", Economic Journal, Vol. 126/590, http://dx.doi.org/10.1111/ecoj.12206.

Arnold, J., B. Javorcik and A. Mattoo (2011), "Does services liberalization benefit manufacturing firms?. Evidence from the Czech Republic", Journal of International Economics, Vol. 85/1, http://dx.doi.org/10.1016/j.jinteco.2011.05.002.

Artopoulos, A., D. Friel and J. Hallak (2013), "Export emergence of differentiated goods from developing countries: Export pioneers and business practices in Argentina", Journal of Development Economics, Vol. 105, pp. 19-35, http://dx.doi.org/10.1016/J.JDEVECO.2013.07.001. 
Baer, N. (2018), "Con el Saocom 1A, la familia satelital made in Argentina suma su quinto integrante", La Nacion, https://www.lanacion.com.ar/2160896-con-el-saocom-1a-la-familiasatelital-made-in-argentina-suma-su-quinto-integrante.

Baldwin, R. (2006), "Multilateralising Regionalism: Spaghetti Bowls as Building Blocs on the Path to Global Free Trade", The World Economy, Vol. 29/11, pp. 1451-1518, http://dx.doi.org/10.1111/j.1467-9701.2006.00852.x.

Baldwin, R. and S. Evenett (2009), The collapse of global trade, murky protectionism, and the crisis: Recommendations for the G20, Centre for Economic Policy Research (CEPR), http://www.cepr.org (accessed on 18 September 2018).

Barrientos, S., G. Gereffi and A. Rossi (2011), "Economic and social upgrading in global production networks: A new paradigm for a changing world", International Labour Review, Vol. 150/3-4, pp. 319-340, http://dx.doi.org/10.1111/j.1564-913X.2011.00119.x.

Bas, M. (2012), "Input-trade liberalization and firm export decisions: Evidence from Argentina", Journal of Development Economics, Vol. 97/2, pp. 481-493, http://dx.doi.org/10.1016/J.JDEVECO.2011.05.010.

Bechichi, N. et al. (2018), "Moving Between Jobs An Analysis of Occupation Distances and Skill Needs", OECD Science, Technology and Innovation Policy Papers, No. 52, OECD, Paris, http://www.oecd.org/going-digital (accessed on 27 September 2018).

Bergemann, A. and G. Van Den Berg (2006), Active labour market policy effects for women in Europe - a survey, http://dx.doi.org/10.1920/wp.ifs.2006.0626.

Bernard, A., I. Van Beveren and H. Vandenbussche (2014), "Multi-Product Exporters and the Margins of Trade", Japanese Economic Review, Vol. 65/2, pp. 142-157, http://dx.doi.org/10.1111/jere.12030.

Blalock, G. and P. Gertler (2009), "How firm capabilities affect who benefits from foreign technology", Journal of Development Economics, Vol. 90/2, pp. 192-199, https://ideas.repec.org/a/eee/deveco/v90y2009i2p192-199.html (accessed on 4 October 2018).

Blalock, G. and F. Veloso (2007), "Imports, Productivity Growth, and Supply Chain Learning”, World Development, Vol. 35/7, pp. 1134-1151, http://dx.doi.org/10.1016/j.worlddev.2006.10.009.

Bown, C. and M. Crowley (2013), "Import protection, business cycles, and exchange rates: Evidence from the Great Recession", Journal of International Economics, Vol. 90/1, pp. 5064, http://dx.doi.org/10.1016/J.JINTECO.2012.12.001.

Bown, C. and P. Tovar (2016), MERCOSUR is not really a free trade agreement, let alone a customs union | VOX, CEPR Policy Portal, https://voxeu.org/article/mercosur-not-really-freetrade-agreement-let-alone-customs-union (accessed on 27 September 2018).

Brambilla, I., N. Depetris Chauvin and G. Porto (2017), "Examining the Export Wage Premium in Developing Countries", Review of International Economics, Vol. 25/3, pp. 447-475, http://dx.doi.org/10.1111/roie.12231. 
Brandt, L., J. Van Biesebroeck and Y. Zhang (2012), "Creative accounting or creative destruction? Firm-level productivity growth in Chinese manufacturing", Journal of Development Economics, Vol. 97/2, pp. 339-351, http://dx.doi.org/10.1016/J.JDEVECO.2011.02.002.

Broda, C. and D. Weinstein (2006), "Globalization and the Gains From Variety", The Quarterly Journal of Economics, Vol. 121/2, pp. 541-585, http://dx.doi.org/10.1162/qjec.2006.121.2.541.

Busso, M., L. Madrigal and C. Pagés (2013), "Productivity and resource misallocation in Latin America", The B.E. Journal of Macroeconomics, Vol. 13/1, pp. 1-30, https://ideas.repec.org/a/bpj/bejmac/v13y2013i1p30n3.html (accessed on 4 October 2018).

Bustos, P. (2011), "Trade Liberalization, Exports, and Technology Upgrading: Evidence on the Impact of MERCOSUR on Argentinian Firms", American Economic Review, Vol. 101, pp. 304-340, http://dx.doi.org/10.1257/aer.101.1.304.

Cabrer-Borrás, B. and G. Serrano-Domingo (2007), "Innovation and R\&amp;D spillover effects in Spanish regions: A spatial approach", Research Policy, Vol. 36/9, pp. 1357-1371, http://dx.doi.org/10.1016/J.RESPOL.2007.04.012.

Cadestin, C., J. Gourdon and P. Kowalski (2016), "Participation in Global Value Chains in Latin America: Implications for Trade and Trade-Related Policy", OECD Trade Policy Papers, No. 192, OECD Publishing, Paris, http://dx.doi.org/10.1787/5jlpq80ts8f2-en.

Cadot, O., J. Gourdon and F. van Tongeren (2018), "Estimating Ad Valorem Equivalents of Non-Tariff Measures: Combining Price-Based and Quantity-Based Approaches", OECD Trade Policy Papers, No. 215, OECD Publishing, Paris, http://dx.doi.org/10.1787/f3cd5bdcen.

Cecchini, S. and A. Madariaga (2011), "Conditional Cash Transfer Programmes: The Recent Experience in Latin America and the Caribbean", Cuadernos de la CEPAL, Vol. 95, http://dx.doi.org/10.2139/ssrn.1962666.

Clarin (2018), "Acuerdo histórico con China para el ingreso de la carne argentina - 17/05/2018 Clarín.com", Clarin, https://www.clarin.com/economia/acuerdo-historico-china-ingresocarne-argentina_0_SyPrpuiAz.html (accessed on 29 September 2018).

Criscuolo, C., P. Gal and C. Menon (2014), "The Dynamics of Employment Growth: New Evidence from 18 Countries", OECD Science, Technology and Industry Policy Papers, No. 14, OECD Publishing, Paris, http://dx.doi.org/10.1787/5jz417hj6hg6-en.

Criscuolo, C. and J. Timmis (2018), "GVCS and centrality: Mapping key hubs, spokes and the periphery”, OECD Productivity Working Papers, Vol. 12, https://doi.org/10.1787/d4a9bd6fen (accessed on 15 September 2018).

Criscuolo, C. and J. Timmis (2018), "The Changing Structure of Global Value Chains: Are Central Hubs Key for Productivity?”, International Productivity Monitor, Vol. 34, pp. 64-80, https://ideas.repec.org/a/sls/ipmsls/v34y20184.html (accessed on 4 October 2018). 
Cumming, D. (2012), "Measuring the Effect of Bankruptcy Laws on Entrepreneurship Across Countries", Journal of Entrepreneurial Finance, Vol. 16/1, pp. 80-86, https://econpapers.repec.org/article/pepjournl/v 3a16 3ay 3a2012 3ai 3a1 3ap 3a8086.htm (accessed on 1 October 2018).

De Loecker, J. et al. (2016), "Prices, Markups, and Trade Reform", Econometrica, Vol. 84/2, pp. 445-510, http://dx.doi.org/10.3982/ECTA11042.

Dragún, E. and G. F. (eds.) (2019), Proyectando la una inserción inteligente en el corto y mediano plazo., UIA-ILO.

Eric Bartelsman, B. et al. (2013), "Cross-Country Differences in Productivity: The Role of Allocation and Selection $\uparrow$ We are indebted for many useful comments on earlier drafts and presentations to", American Economic Review, Vol. 103/1, pp. 305-334, http://dx.doi.org/10.1257/aer.103.1.305.

Essaji, A. (2008), "Technical regulations and specialization in international trade", Journal of International Economics, Vol. 76/2, pp. 166-176, http://dx.doi.org/10.1016/J.JINTECO.2008.06.008.

European Commission (2018), Report on the protection and enforcement of intellectual property rights in third countries, http://trade.ec.europa.eu/doclib/docs/2018/march/tradoc_156634.pdf (accessed on 30 January 2019).

Fajgelbaum, P. and A. Khandelwal (2016), "Measuring the Unequal Gains from Trade*", The Quarterly Journal of Economics, pp. 1113-1181, http://dx.doi.org/10.1093/qje/qjw013.

Fajgelbaum, P. and A. Khandelwal (2016), "MEASURING THE UNEQUAL GAINS FROM TRADE*", The Quarterly Journal of Economics, pp. 1113-1181, http://dx.doi.org/10.1093/qje/qjw013.

Foster, L. et al. (2018), "Innovation, Productivity Dispersion, and Productivity Growth", NBER Working Paper, No. 24420, National Bureau of Economic Research, Cambridge, MA, http://dx.doi.org/10.3386/w24420.

Galgóczi, B. (2014), “The Long and Winding Road from Black to Green: Decades of Structural Change in the Ruhr Region", International Journal of Labour Research, Vol. 6/2, p. 217, https://www.questia.com/library/journal/1P3-3771936601/the-long-and-winding-road-fromblack-to-green-decades (accessed on 14 December 2018).

Gayá, R. (2017), "Strengthening knowledge-based services in Argentina", Revista de Administração Mackenzie, Vol. 18/6, pp. 96-123, http://dx.doi.org/10.1590/167869712017/administracao.v18n6p96-123.

Goldberg, K. and N. Pavcnik (2007), Distributional Effects of Globalization in Developing Countries, https://pubs.aeaweb.org/doi/pdfplus/10.1257/jel.45.1.39 (accessed on 14 September 2018).

Goldberg, P. et al. (2009), "Trade Liberalization and New Imported Inputs", American Economic Review, Vol. 99/2, pp. 494-500, http://dx.doi.org/10.1257/aer.99.2.494. 
González Pandiella, A. (2014), "Moving Towards a More Dynamic Business Sector in Spain", OECD Economics Department Working Papers, No. 1173, OECD Publishing, Paris, http://dx.doi.org/10.1787/5jxszm2k7fnw-en.

Gravelle, H. and R. Rees (2004), Microeconomics, Prentice Hall Financial Times.

Grundke, R. et al. (2017), "Skills and global value chains: A characterisation", OECD Science, Technology and Industry Working Papers, No. 2017/05, http://dx.doi.org/10.1787/cdb5de9ben.

Grundke, R. et al. (2018), "Which skills for the digital era?: Returns to skills analysis", $O E C D$ Science, Technology and Industry Working Papers, No. 2018/09, OECD Publishing, Paris, http://dx.doi.org/10.1787/9a9479b5-en.

Grundke, R. and C. Moser (2019), "Hidden Protectionism? Evidence from Non-tariff Barriers to Trade in the United States", Journal of International Economics, Vol. 117, pp. 143-157, https://doi.org/10.1016/j.jinteco.2018.12.007 (accessed on 18 September 2018).

He, Z. and M. Dai (2017), "Learning by Importing”, Columbia University, http://www.columbia.edu/ zh2178/Learning\%20by\%20Importing.pdf (accessed on 22 September 2018).

Hidalgo, C. et al. (2007), "The Product Space Conditions the Development of Nations", Science, Vol. 317.

Hsieh, C. and P. Klenow (2009), "Misallocation and Manufacturing TFP in China and India", Quarterly Journal of Economics, Vol. 124/4, pp. 1403-1448, http://dx.doi.org/10.1162/qjec.2009.124.4.1403.

Iglesias, L. (2018), “Avanza la ventanilla única de comercio exterior - LA NACION”, La Nacion, https://www.lanacion.com.ar/2162786-avanza-la-ventanilla-unica-de-comercioexterior (accessed on 29 September 2018).

ILO (2016), What Works - Active Labour Market Policies in Latin America, Brookings Institution Press, Washington, DC., https://www.brookings.edu/book/what-works-activelabour-market-policies-in-latin-america-and-the-caribbean/ (accessed on 5 October 2018).

IMF (2017), Cluster Report: Trade Integration in Latin America and the Caribbean, https://www.imf.org/en/Publications/CR/Issues/2017/03/10/Cluster-Report-TradeIntegration-in-Latin-America-and-the-Caribbean-44735 (accessed on 5 October 2018).

INET (2016), Demanda de Capacidades 2020 - Análisis de la demanda de capacidades laborales en la Argentina, Insituto Nacional de Educación Technológica, https://docplayer.es/27101991-Demanda-de-capacidades-analisis-de-la-demanda-decapacidades-laborales-en-la-argentina.html (accessed on 8 October 2018).

Jouanjean, M. (2012), Market Access \&amp; Food Standards : Insights from the Implementation of US Sanitary and Phytosanitary Regulation, Science Po Paris, http://spire.sciencespo.fr/hdl:/2441/7o52iohb7k6srk09n20k7c4r6. 
Jouanjean, M., J. Maur and B. Shepherd (2012), "Reputation Matters Spillover Effects in the Enforcement of US SPS Measures", Policy Research Working Paper, No. 5935, World Bank, http://econ.worldbank.org. (accessed on 29 September 2018).

Klapper, L. et al. (2006), "Entry regulation as a barrier to entrepreneurship \$ We thank William Schwert, an anonymous referee", Journal of Financial Economics, Vol. 82, pp. 591-629, http://dx.doi.org/10.1016/j.jfineco.2005.09.006.

Kleibergen, F. and R. Paap (2006), "Generalized reduced rank tests using the singular value decomposition", Journal of the American Statistical Association, Vol. 133, p. 766, http://dx.doi.org/10.1016/j.jeconom.2005.02.011.

Levy-Carciente, S. and L. Montanari (2018), International property rights index, Property Rights [96] Alliance, Washington, DC, https://www.internationalpropertyrightsindex.org/full-report (accessed on 30 January 2019).

Lopez Gonzalez, J. (2016), "Using Foreign Factors to Enhance Domestic Export Performance: A Focus on Southeast Asia", OECD Trade Policy Papers, No. 191, OECD Publishing, Paris, http://dx.doi.org/10.1787/5jlpq82v1jxw-en.

López González, J. (2017), "Mapping the participation of ASEAN small- and medium- sized enterprises in global value chains", OECD Trade Policy Papers, No. 203, OECD Publishing, Paris, http://dx.doi.org/10.1787/2dc1751e-en.

Lopez Mourelo, E. and V. Escudero (2017), "Effectiveness of Active Labor Market Tools in Conditional Cash Transfers Programs: Evidence for Argentina", World Development, Vol. 94, pp. 422-447, http://dx.doi.org/10.1016/j.worlddev.2017.02.006.

Martínez Licetti, M. et al. (2018), Strengthening Argentina's Integration into the Global Economy: Policy Proposals for Trade, Investment, and Competition, The World Bank, http://dx.doi.org/10.1596/978-1-4648-1275-0.

Maskus, K. and J. Wilson (2001), Quantifying the impact of technical barriers to trade : can it be done?, University of Michigan Press, https://books.google.fr/books?hl=fr\&lr=\&id=inhIAHBdvUsC\&oi=fnd\&pg=PR7\&dq=maskus tproduct+standards\&ots $=q 15 \mathrm{rcPzTKz} \& \operatorname{sig}=\mathrm{S}$ -

0jXYbZfeK2B1XpbKbwMu8rk0k\#v=onepage $\& \mathrm{q}=$ =maskus\%20product\%20standards $\& \mathrm{f}=\mathrm{false}$ (accessed on 28 September 2018).

Melitz, M. (2003), The Impact of Trade on Intra-Industry Reallocations and Aggregate Industry Productivity, https://www.jstor.org/stable/pdf/1555536.pdf?refreqid=excelsior\%3Ae3382ca8aee44f583882 d975e0cdb85e (accessed on 22 September 2018).

MINCYT (2015), Indicadores de Ciencia y Tecnología Argentina, http://indicadorescti.mincyt.gob.ar/documentos/indicadores 2015.pdf.

Moïsé, E. and S. Sorescu (2013), "Trade Facilitation Indicators: The Potential Impact of Trade Facilitation on Developing Countries' Trade", OECD Trade Policy Papers, No. 144, OECD Publishing, Paris, http://dx.doi.org/10.1787/5k4bw6kg6ws2-en. 
O'Connell, S. et al. (2017), "Can business input improve the effectiveness of worker training? evidence from Brazil's Pronatec-MDIC", Policy Research Working Paper, No. WPS8155, World Bank, http://documents.worldbank.org/curated/en/444871501522977352/Canbusiness-input-improve-the-effectiveness-of-worker-training-evidence-from-BrazilsPronatec-MDIC (accessed on 5 October 2018).

OECD (2019), OECD Food and Agricultural Reviews: Agricultural Policies in Argentina, OECD Publishing, Paris.

OECD (2019), Regulatory Policy in Argentina: Tools and Practices for Regulatory Improvement, OECD Reviews of Regulatory Reform, OECD Publishing, Paris, https://dx.doi.org/10.1787/d835e540-en.

OECD (2018), OECD Skills for jobs database, https://www.oecdskillsforjobsdatabase.org/\#FR/_.

OECD (2017), Competition Assessment Toolkit: Volume 2. Guidance, http://www.oecd.org/competition/toolkit.

OECD (2017), Economic Policy Reforms 2017: Going for Growth, https://doi.org/10.1787/growth-2017-en.

OECD (2016), Economic Policy Reforms 2016: Going for Growth Interim Report, OECD Publishing, Paris, https://dx.doi.org/10.1787/growth-2016-en.

OECD (2016), OECD Territorial Reviews: Córdoba, Argentina, OECD Territorial Reviews, OECD Publishing, Paris, https://dx.doi.org/10.1787/9789264262201-en.

OECD (2015), Policy Framework for Investment, 2015 Edition, OECD Publishing, Paris, https://dx.doi.org/10.1787/9789264208667-en.

OECD (2014), OECD Economic Surveys: Spain 2014, OECD Publishing, Paris, https://dx.doi.org/10.1787/eco_surveys-esp-2014-en.

OECD (2011), OECD Reviews of Regional Innovation: Basque Country, Spain 2011, OECD Reviews of Regional Innovation, OECD Publishing, Paris, https://dx.doi.org/10.1787/9789264097377-en.

Olarreaga, M. and I. Soloaga (1998), "Endogenous Tariff Formation: The Case of Mercosur", The World Bank Economic Review, Vol. 12/2, pp. 297-320, http://documents.worldbank.org/curated/en/322031468287366548/pdf/772690JRN0WBER0 Box0377301B00PUBLIC0.pdf (accessed on 27 September 2018).

Oliveira, D. (2018), “Tecnológicas en alerta por la caída de promociones de la Ley del Software | El Cronista", El Cronista, https://www.cronista.com/negocios/Tecnologicas-en-alerta-por-lacaida-de-promociones-de-la-Ley-del-Software-20180125-0037.html (accessed on 1 October 2018). 
Pavcnik, N. (2002), "Trade Liberalization, Exit, and Productivity Improvements: Evidence from Chilean Plants", The Review of Economic Studies, Vol. 69/1, pp. 245-276, http://dx.doi.org/10.1111/1467-937X.00205.

Pieczynski, D. (2016), Employee Turnover Slows in Brazil, Even as the Tech Sector Remains an [60] Economic Bright Spot, Radford Consulting, https://radford.aon.com/insights/articles/2016/Employee-Turnover-Slows-in-Brazil (accessed on 4 October 2018).

Polansek, T. (2017), "USDA says no more delays to rule allowing Argentina lemon imports", Reuters, https://www.reuters.com/article/us-argentina-lemons-usa-idUSKBN17X2FA.

Porto, G. (2006), "Using survey data to assess the distributional effects of trade policy", Journal of International Economics, Vol. 70/1, pp. 140-160, http://dx.doi.org/10.1016/J.JINTECO.2005.09.003.

Sanderson, E. and F. Windmeijer (2016), “A weak instrument F-test in linear IV models with multiple endogenous variables ${ }^{3}$ ”, Journal of Econometrics, Vol. 190, pp. 212-221, http://dx.doi.org/10.1016/j.jeconom.2015.06.004.

Sarmiento, A., K. Lucenti and A. Garcia (2010), "Automating the Control of Goods in International Transit : Implementing the TIM in Central America", IFC Smart Lessons Brief, https://openknowledge.worldbank.org/handle/10986/10495 (accessed on 29 September 2018).

Schwab, K. (2018), The Global Competitiveness Report 2017-2018, World Economic Forum, http://www3.weforum.org/docs/GCR20172018/05FullReport/TheGlobalCompetitivenessReport2017\%E2\%80\%932018.pdf (accessed on 26 September 2018).

Topalova, P. and A. Khandelwal (2011), "Trade Liberalization and Firm Productivity: The Case of India", The Review of Economics and Statistics, Vol. 93/3, pp. 995-1009, http://dx.doi.org/10.1162/REST_a_00095.

Trefler, D. (1993), "Trade Liberalization and the Theory of Endogenous Protection: An Econometric Study of U.S. Import Policy”, Journal of Political Economy, Vol. 101/1, pp. 138-60, http://www.journals.uchicago.edu/t-and-c (accessed on 19 September 2018).

USTR (2018), Office of the United States Trade Representative 2018 Special 301 Report, https://ustr.gov/sites/default/files/files/Press/Reports/2018\%20Special\%20301.pdf (accessed on 30 January 2019).

Winters, L., N. Mcculloch and A. Mckay (2004), "Trade Liberalization and Poverty: The Evidence so Far", Journal of Economic Literature, Vol. 42/1, pp. 72-115, https://www.jstor.org/stable/pdf/3217037.pdf?refreqid=excelsior\%3Afb2fd700a65867707fdd c544b380482d (accessed on 14 September 2018).

World Bank (2018), Doing Business 2018. 
World Bank (2016), Argentina Country Environmental Analysis Second Edition, World Bank, https://openknowledge.worldbank.org/bitstream/handle/10986/25775/109527-ENGLISHPUBLIC-ARG-CEA-Country-Environmental-AnalysisEnglish.pdf?sequence $=1$ \&isAllowed $=y$ (accessed on 30 September 2018).

WTO (2012), World Trade Report 2012: Trade and public policies: A closer look at non-tariff [9] measures in the 21 st century, http://www.wto.org (accessed on 19 September 2018). 


\section{Annex A}

\section{Annex A.1. The consumption side analysis}

To investigate the effects of a reduction in import tariffs and non-tariff measures on household welfare across the income distribution, this paper uses data from the Argentinian household survey "Encuesta Nacional de Gastos de los Hogares (ENGHO)" from the year 2012 and 2013. The analysis follows parts of the methodology used in Porto (2006) and simulates the partial equilibrium effects of a 50\% (100\%) cut in tariffs and non-tariff measures (NTMs) on household welfare. This method estimates only the direct effects of consumer price changes on the purchasing power of households across the income distribution. Additional indirect effects of trade-induced price changes that work through the production side changing the factor incomes of households are not considered here.

To compute the changes in domestic consumer prices induced by a cut in tariffs and nontariff barriers, this study uses the simplifying assumption that a change in import prices is directly passed on to domestic prices of tradable goods, as data on product-specific market structures is not available. The analysis also abstracts from cross-price effects on prices of non-tradable goods. With these assumptions, the percentage change of the domestic consumer price $\mathrm{p}$ for the tradable good $\mathrm{k}$ in reaction to a change in the tariff level $\tau$ for good $\mathrm{k}$ can be expressed as:

$$
\frac{d p_{k}}{p_{k}}=\frac{1}{1+\tau_{k}} d \tau_{k}
$$

To evaluate the welfare changes induced by changes in consumer prices, this study builds on Porto (2006) and assumes that households maximise utility by choosing the consumption of tradable and non-tradable goods subject to their resource constraint and the price vectors of tradable and non-tradable goods ( $\mathbf{p}$ and $\mathbf{r}$, respectively). By assuming away savings, at the optimum in time $\mathrm{t}=0$, the expenditure function $\mathrm{e}()$, i.e. the amount spent on the optimal consumption choices, equals the total exogenous income $w$ of the household $j$ :

$$
e_{t=0}^{j}\left(\boldsymbol{p}_{t=0}, \boldsymbol{r}_{t=0}, u_{t=0}^{j}\right)=w_{t=0}^{j}
$$

The effects of trade-induced price reductions on household welfare are evaluated using the compensating variation $(\mathrm{CV})$, which measures how much the expenditure can be decreased when consumer prices fall so that the utility level remains the same than before the price decrease (Gravelle and Rees, $\left.2004_{[98]}\right){ }^{2}$ The compensating variation as a share of the total exogenous income of the household $\mathrm{j}$ following a change in the price of the tradable good $\mathrm{k}$ can be expressed as:

$$
\frac{C V_{k}^{j}\left(p_{k, t=1,} \boldsymbol{p}_{t=0}, \boldsymbol{r}_{t=0}, u_{t=0}^{j}\right)}{w_{t=0}^{j}}=s_{k, t=0}^{j} \frac{d p_{k}}{p_{k}}
$$

\footnotetext{
${ }^{2}$ Note that welfare changes could also be measured by the equivalent variation or by changes in the consumers' surplus. The choice for using the compensating variations is driven by the possibility of empirical identification. Potential differences in measurement depend on the income effect following a price change. For normal goods, the compensating variation is lower than the equivalent variation meaning that it is a conservative measure of welfare change.
} 
Where $s_{k}{ }^{j}$ is the share of the total expenditure of household $j$ (or income, as savings are assumed to be zero) that is spent for tradable good $\mathrm{k}$ in time $\mathrm{t}=0$. As the prices of nontradable goods are assumed to be constant in reaction to a change in import tariffs, the total compensating variation for household $\mathrm{j}$ is computed by summing up equation (3) across all tradable goods whose prices change due to the tariff cuts. Finally, the average compensating variation (as a share of household income) by household income decile is computed by averaging across all households within the same income decile.

To compute the price changes of tradable goods in reaction to cuts in tariffs according to equation (1), this study uses tariff data for the year 2018 from the Ministry of Production of Argentina (at the ISIC rev 3 digit level) as well as more disaggregated tariff data from the World Bank WITS database for the year 2017 (at the SITC 3 digit as well as HS 4 digit level). Using different data sources was necessary to achieve concordance with the product classification used in the Argentinian household survey ENGHO, which is different from the standard product classifications used in trade statistics.

To simulate changes in the ad-valorem-equivalents (AVEs) of non-tariff measures (NTMs) for Argentina, data from recent OECD work has been used (Cadot, Gourdon and van Tongeren, $\left.2018_{[14]}\right)$. That work computes AVEs for NTM by end use category for ISIC Rev. 3 sectors. The analysis uses the AVEs for the end-use category final consumption goods to capture the effects of a decrease of NTMs on the prices of consumption goods. The budget shares for all tradable goods for each household $\left(\mathrm{sk}_{\mathrm{k}}^{\mathrm{j}}\right)$ are taken from the Argentinian household survey "Encuesta Nacional de Gastos de los Hogares (ENGHO)" from the year 2012 and 2013, which is the latest edition available.

This study simulates several trade liberalization scenarios. In the baseline, tariffs and nontariff measures are cut by $100 \%$ and the results for household welfare across the income distribution are compared with a scenario where only tariffs are cut by $100 \%$. The estimates suggest that Argentinian consumers could see their purchasing power increase by around $25 \%$ on average under the ambitious scenario of a full removal of trade barriers, far exceeding the estimated purchasing power increases of around $11.5 \%$ if only tariffs are removed (Figure 13). If in a less ambitious scenario tariffs and NTMs are only reduced by $50 \%$, consumer welfare gains are about half the magnitude of the full-liberalisation baseline (Figure A.1). 


\section{Annex Figure A.1. Potential consumer benefits from lowering trade barriers by 50\%}

Increases in real purchasing power (relative to total expenditures) due to a reduction of tariffs and/or non-tariff measures (NTMs) by $50 \%$ for each household income decile (in \%).
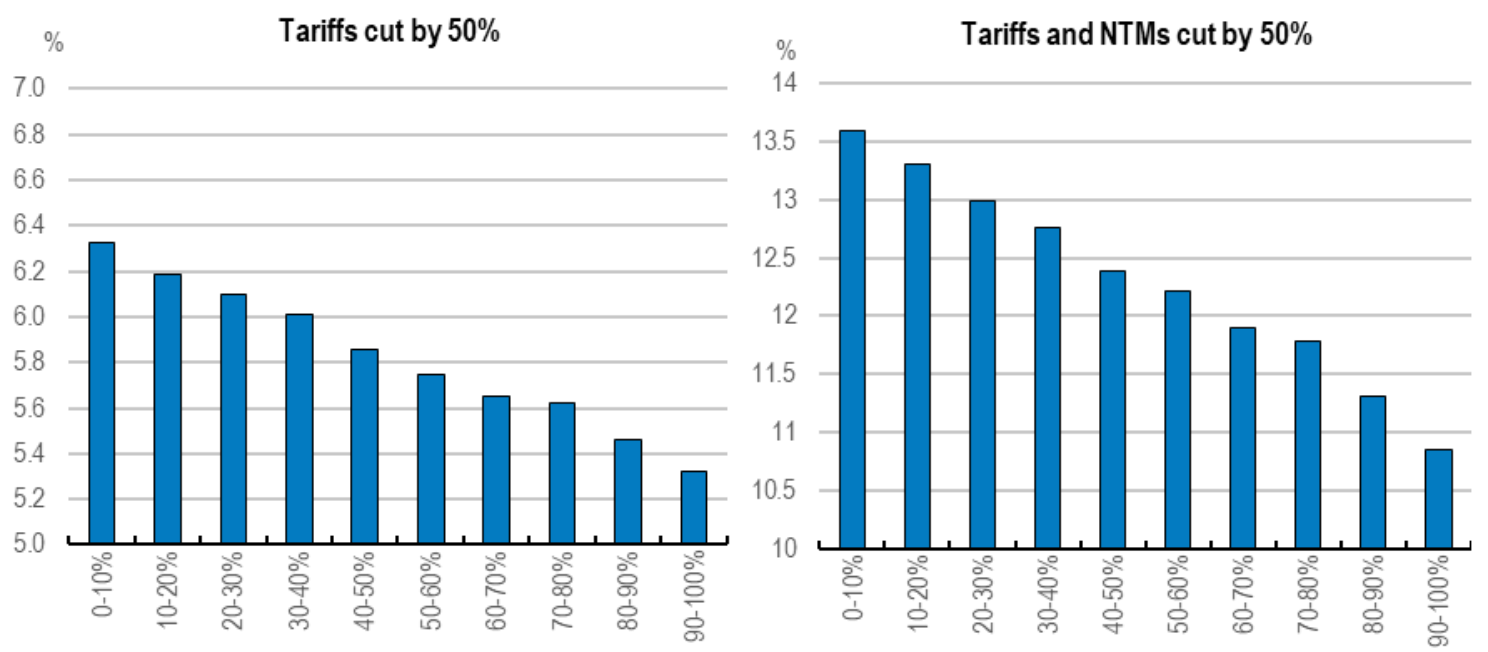

Note: The $\mathrm{x}$-axis shows the ten income deciles of the household income distribution, starting with the poorest decile (0-10\%). Ad-valorem equivalents of non-tariff measures (NTMs) for Argentina are taken from Cadot, Gourdon and van Tongeren (2018). Tariff rates at the detailed product level are taken from WITS and from data sent by the Ministry of Production of Argentina.

Source: OECD calculations based on the Argentinian household survey ENGH 2012/2013.

\section{Annex A.2. Analysis of industry level effects of trade protection}

\section{The links between input tariffs and economic activity}

To investigate how sectoral economic activity, productivity and exports have reacted to changes in input tariffs over the past 20 years in Argentina, this paper uses a sectoral panel dataset for Argentina from 1995 until 2016, which provides information on average sector input tariffs, employment, average real wages, production, value added as well as several indicators for the integration into global value chains. Data on production, value added and various measures for sector specific integration into the world economy are available for 1995-2011 and are taken from the OECD Trade in Value Added (TiVA) database (Dec 2016). Data are available for 2 natural resource and 16 manufacturing and 17 services sectors (33 sectors in total). Data on sector level formal employment and average wages is available from the national statistics institute INDEC for the years 1996-2016 at the level of 32 industries (data for public administration and defence are missing). Additional preliminary OECD TiVA data for the years 1995-2015 and 33 sectors is used in robustness checks.

To quantify average sector-level input protection over 1995-2016, this study uses time series data on import tariffs for intermediate inputs from the OECD, in addition to detailed data on input use by sector based on the Argentinian input-output matrix for the year 2004. OECD tariff data aggregate average input tariffs to the sectoral level using weighted averages of input tariff lines within the economic sector, using import values as weights. Product-level tariffs for inputs are applied tariff rates (AHS) at the HS 8 digit level, with inputs defined according to a novel OECD classification that classifies goods as 
intermediates, capital goods or final consumption goods. Where applied tariff rates are not available, preferential rates or most-favoured nation (MFN) rates are taken instead.

The sector-level tariff data are then weighted using input-output coefficients to obtain measures of input protection for each final goods sector. The input-output coefficients are constructed as the share of inputs from the origin sector in total input use of the final sector. This allowed constructing average input tariffs for 33 economic sectors over the years 1995-2016.

To analyse the effects of input protection on sectoral economic activity, productivity, employment and wages, the following regressions are estimated for each of the eight dependent variables (in logs) shown in Table 2 using a fixed effects estimator:

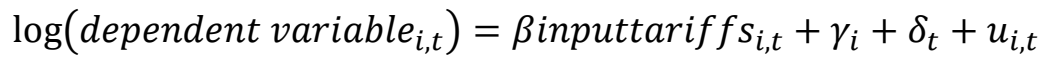

Where the subscript $i$ denotes the sector and $t$ the year. The independent variable of interest is the average input tariff for the economic sector (inputtariffs). Fixed effects for the economic sector $\left(\gamma_{\mathrm{i}}\right)$ control for all unobservable time-invariant sector-specific characteristics and time fixed effects $\left(\delta_{t}\right)$ for all macroeconomic effects that affect all economic sectors alike. Robust standard errors are used to account for potential heteroscedasticity.

The main results show a strong negative link between average input tariffs and sectoral output, employment, value added, exports and value added exports (Table 2). The negative association is significant at the 5\% level for these five dependent variables. For example, an increase in average input tariffs by 1 percentage point is associated with a decrease in production by $1.8 \%$. There is no significant link between average input tariffs and labour productivity at the sectoral level, because both output and employment decrease due to an increase in input tariffs. Wages show a slight positive association, but the coefficient is not significant at the $5 \%$ level.

A set of unreported robustness checks has been undertaken and is available on request. These include a specification in which the tariff measure enters with a one-year lag, obtaining similar results. Endogeneity concerns are somewhat mitigated in this set-up, as the input tariff measure is a weighted average across all economic sectors and less likely to be simultaneously affected by the economic activity of the specific final sector. The results are also robust to controlling for the level of output protection at the sectoral level. Finally, regressions restricting the sample size to be equal across dependent variables, show similar results. The baseline regressions include the maximal available sample size for each dependent variable. As data for some dependent variables was not available for some years or some sectors, sample sizes for the regressions differ between dependent variables.

\section{The links between output tariffs and economic activity}

To investigate how sectoral economic activity, productivity and exports have reacted to changes in sectoral output tariffs over the past 20 years in Argentina, this study uses the same sectoral panel dataset for Argentina from 1995 until 2016 described in the preceding section, adding average output tariffs at the sectoral level for Argentina taken from OECD tariff data. As output tariffs are not available for services sectors, the dataset includes 2 natural resource and 16 manufacturing sectors. The dataset provides information on average sectoral output tariffs, employment, average wages, production, value added as well as several indicators for the integration into global value chains. 
To analyse the effects of output protection on sectoral economic activity, productivity, employment and wages, the following regressions are estimated for each of the eight dependent variables (in logs) shown in Table 4 using fixed effects estimation:

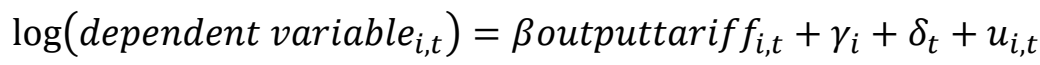

Where the subscript $i$ denotes the sector and $t$ the year. The independent variable of interest is the average output tariff for the economic sector (outputtariff). Fixed effects for the economic sector $\left(\gamma_{i}\right)$ control for all unobservable time-invariant sector-specific characteristics, while time fixed effects $\left(\delta_{t}\right)$ control for all macroeconomic effects that affect all economic sectors alike. Robust standard errors are used to account for heteroscedasticity. In robustness checks, the tariff measure enters with a one year lag, leading to similar results available upon request. The number of observations varies across regressions due to differences in the number of missing values across variables, but regressions restricting the sample size to be equal across dependent variables, show similar results.

The baseline results show a strong negative link between average output tariffs and sectoral production, value added and labour productivity in output and value added terms (Table 4). The negative association is statistically significant at the $5 \%$ level for these four dependent variables. They are also economically significant. For example, an increase of average output tariffs by 1 percentage point is associated with a decrease in output per worker by $2.6 \%$. By contrast, no significant link between average output tariffs and exports and wages at the sectoral level has been detected. With respect to employment effects, the picture is slightly more complex. On average across sectors, employment is significantly positively associated with protection, with an increase in tariffs by 1 percentage points corresponding to an increase in employment by $0.7 \%$. It turns out, however, that this result is driven by only a few economic sectors, namely textiles, wearing apparel, footwear and other transport equipment, and breaks down once these are excluded.

\section{Endogeneity issues}

As sectors with a negative output shock might be targeted by higher import protection, sectoral output tariffs might be correlated with the error term due to simultaneity, leading to possible downward bias of the coefficients in the fixed effects estimation of equation (5). To address these possible endogeneity issues, equation (5) is estimated using instrumental variables.

The instrument used for Argentinian sectoral output tariffs are sectoral output shocks in Brazil in the previous year. This instrument is likely to have explanatory power because Brazil and Argentina are part of the same customs union (Mercosur) and tariff changes are joint decisions. At the same time, Brazil is by far the largest economy in the block and therefore likely has strong weight in Mercosur decisions. If Brazil receives a negative output shock in a specific sector, firms there might start lobbying for higher tariffs for this sector within the customs union. By contrast, the instrument is unlikely to be correlated with output shocks in Argentina. For example, a 2017/2018 drought strongly affected the whole agro-industrial value chain in Argentina, whereas Brazil had a record harvest.

The results of the instrumental variable regressions support the baseline results from the fixed effects regressions (Table A.1). The significant negative effects of output tariffs on production, value added and labour productivity as well as the positive significant effect on employment are preserved, although the magnitude of the effects is larger. The positive employment effects of protection vanish once again when abstracting from two sectors (textiles, wearing apparel, footwear and other transport equipment). However, using 
instrumental variables regressions, output tariffs are found to also have negative significant effects on exports and forward integration into global value chains.

Table A.1 also shows the results for the first stage regression of the instrumental variable estimation as well as tests for the strength of the instrument. As expected, the instrument "Brazil's sectoral output shocks from the previous year" is strongly negatively correlated with Argentina's sectoral output tariffs. The two tests for weak instruments both show that the null hypothesis of weak instruments can be rejected at the 5\% level for each of the instrumental variable regressions (Sanderson and Windmeijer, 2016 $6_{[99]}$; Kleibergen and Paap, 2006 $\left.{ }_{[100]}\right)$.

\section{Annex Table A.1. Effects of output tariffs on economic activity (within economic sectors) - Instrumental Variable (IV) Regressions}

IV regressions control for sector fixed effects and use only variation within economic sectors

\begin{tabular}{|c|c|c|c|c|c|c|c|c|}
\hline & (1) & (2) & (3) & (4) & (5) & (6) & (7) & (8) \\
\hline Dependent Variables: & $\begin{array}{l}\text { Log of } \\
\text { employment }\end{array}$ & $\begin{array}{l}\text { Log of } \\
\text { production }\end{array}$ & $\begin{array}{l}\text { Log of } \\
\text { value } \\
\text { added }\end{array}$ & $\begin{array}{l}\text { Log of } \\
\text { output per } \\
\text { worker }\end{array}$ & $\begin{array}{c}\text { Log of } \\
\text { value } \\
\text { added per } \\
\text { worker }\end{array}$ & $\begin{array}{l}\log \text { of } \\
\text { exports }\end{array}$ & $\begin{array}{l}\text { Log of } \\
\text { value } \\
\text { added } \\
\text { exports }\end{array}$ & $\begin{array}{l}\text { Log of } \\
\text { real } \\
\text { wages }\end{array}$ \\
\hline \multirow[t]{2}{*}{ Average output tariffs } & $0.023^{*}$ & $-0.062^{* *}$ & $-0.063^{* *}$ & $-0.103^{\star \star \star}$ & $-0.104^{* \star *}$ & $-0.149^{* *}$ & $-0.139^{\star *}$ & -0.005 \\
\hline & $(0.013)$ & $(0.024)$ & $(0.026)$ & $(0.030)$ & $(0.033)$ & $(0.062)$ & $(0.058)$ & $(0.007)$ \\
\hline Sector FE & Yes & Yes & Yes & Yes & Yes & Yes & Yes & Yes \\
\hline Year FE & Yes & Yes & Yes & Yes & Yes & Yes & Yes & Yes \\
\hline Observations & 306 & 288 & 288 & 288 & 288 & 288 & 288 & 306 \\
\hline R-squared & 0.820 & 0.884 & 0.840 & 0.340 & 0.319 & 0.454 & 0.426 & 0.993 \\
\hline Adjusted R-squared & 0.797 & 0.869 & 0.819 & 0.252 & 0.228 & 0.381 & 0.349 & 0.992 \\
\hline First Stage & \multicolumn{8}{|c|}{ Dependent variable: Average output tariffs } \\
\hline \multirow{2}{*}{$\begin{array}{l}\text { Sector specific production in } \\
\text { Brazil (t-1) (in billion USD) }\end{array}$} & $-0.025^{* *}$ & $-0.021^{* * *}$ & $-0.021^{* * *}$ & $-0.021^{\star * *}$ & $-0.021^{* * *}$ & $-0.021^{* * *}$ & $-0.021^{* * *}$ & $-0.025^{\star * *}$ \\
\hline & $(0.006)$ & $(0.006)$ & $(0.006)$ & $(0.006)$ & $(0.006)$ & $(0.006)$ & $(0.006)$ & $(0.006)$ \\
\hline $\begin{array}{l}\text { Partial F-Test Statistic } \\
\text { (Sanderson and Windmeijer, } \\
\text { 2016) }\end{array}$ & 19.45 & 11.38 & 11.38 & 11.38 & 11.38 & 11.38 & 11.38 & 19.45 \\
\hline $\begin{array}{l}\text { Sanderson and Windmeijer } \\
\text { test for the null-hypothesis of } \\
\text { weak instruments ( } p \text {-value) }\end{array}$ & $<0.001$ & $<0.001$ & $<0.001$ & $<0.001$ & $<0.001$ & $<0.001$ & $<0.001$ & $<0.001$ \\
\hline $\begin{array}{l}\text { Kleibergen and Paap test for } \\
\text { the null-hypothesis of } \\
\text { underidentification ( } p \text {-value) }\end{array}$ & $<0.001$ & 0.014 & 0.014 & 0.014 & 0.014 & 0.014 & 0.014 & $<0.001$ \\
\hline
\end{tabular}

Note: The table shows for each dependent variable the results of instrumental variable regressions, whereby the potentially endogenous variable "average output tariffs" is instrumented using sector specific production levels from Brazil from the previous year. In addition to the coefficient estimate for the variable of interest, the table also shows the results for the first stage of the two-stage least squares estimation including two statistic tests for the strength of the instrument developed by Kleibergen and Paap (2006) and Sanderson and Windmeijer (2016), respectively, which test the null-hypothesis of weak instruments or underidentification. Due to data availability issues, the sample sizes vary according to the respective dependent variables. Regressions using the same set of observations show similar results and can be obtained upon request. Robust standard errors in parenthesis, *** $\mathrm{p}<0.01, * * \mathrm{p}<0.05, * \mathrm{p}<0.1$.

Source: OECD calculations based on data from OECD TiVA and INDEC.

\section{Annex A.3. Firm level analysis of multifactor productivity}

To complement the sector-level analysis on the effects of import protection on economic activity, this study uses firm-level panel data for Argentina from the World Bank Enterprise 
survey to investigate the dispersion of firms' multifactor productivity within different sectors of the economy. The analysis allows a more detailed look on the efficiency of the sectoral allocation of resources across firms and can identify sectors where the misallocation of resources is a major explanation for low average productivity. Moreover, the analysis sheds light on the correlates of firm's productivity in the Argentinian economy, in particular on factors related to different structural policy areas.

This study uses firm-level information provided in the World Bank Enterprise Survey for the years 2006, 2010 and 2017 to construct comparable measures of establishment total factor productivity (TFP) in several economic sectors in Argentina. Using information on firm revenue, employment, capital and intermediate input use and the estimator suggested by Levinsohn and Petrin (2003), the following sector-specific production functions in logarithmic form are estimated for the pooled sample of firms across all years:

$$
\begin{aligned}
& \log \left(\text { real_output }_{f, t, k}\right) \\
& \quad=\alpha_{k} \log \left(\text { employment }_{f, t, k}\right)+\beta_{k} \log \left(\text { capital }_{f, t, k}\right) \\
& +\gamma_{k} \log \left(\text { real_inputs }_{f, t, k}\right)+u_{f, t, k}
\end{aligned}
$$

For firm $\mathrm{f}$, in year $\mathrm{t}$ and sector $\mathrm{k}$. Capital is measured as the replacement costs of all equipment and machinery the firm reported in the survey. As services sectors have no capital and intermediate input use reported in the survey, they have been largely excluded from the analysis. In the baseline specification, the nominal variables revenue, capital and inputs are deflated to 2000 Argentinian Pesos using a consumer price index (CPI), based on private sources (Congressional Index) due to data concern regarding the official inflation figures between 2007 and 2016. In robustness checks, sector-specific producer price deflators from the national statistics institute are used and results are similar to the baseline.

The residuals of the estimated sector-specific production functions in equation (6) are taken as a measure for firms total factor productivity (TFP). To make the TFP estimates comparable across economic sectors, they are standardised by the geometric mean of all firms within the economic sector. The TFP estimation was only feasible for five aggregated economic sectors, as the sample does not include sufficient information on firms in other economic sectors. The resulting sample of firms includes 1010 firm-year observations. A robustness check has been undertaken with an index-based productivity measure following Caves, Christensen and Diewert (1982). When using this alternative index, the main results presented in this section continue to hold.

Using the constructed TFP measure for all firms observed in the year 2017, the average productivity of firms was lower in sectors that are subject to higher import protection (Figure 18). Given the discussion of factor allocation above, an interesting question is to what extent differences in the efficiency of factor allocation can explain these productivity differences. The decomposition method suggested by Olley and Pakes (1996) allows such an assessment. Aggregate sector productivity for each sector and year is decomposed into two terms (indices for sector and year are omitted for readability):

$$
\sum_{f=1}^{N}\left(\theta_{f} T F P_{f}\right)=\frac{1}{N} \sum_{f=1}^{N} T F P_{f}+\sum_{f=1}^{N}\left(\theta_{f}-\bar{\theta}\right)\left(T F P_{f}-\overline{T F P}\right)
$$

$\theta_{f}$ is the market share of firm $\mathrm{f}, \mathrm{N}$ is the total number of firms and $\bar{\theta}$ and $\overline{T F P}$ are the average market share and total factor productivity of firms, respectively. In the baseline, value added is used to measure the market share of firms in each sector and year, but results also hold when using employment instead. The first term after the equal sign is the 
unweighted average of firm-level total factor productivity (TFP). The second term is a cross term that captures allocative efficiency. It reflects the extent to which firms with greater total factor productivity have a greater market share (or a larger size). The cross term increases when more productive firms are larger.

An attractive measure of allocative efficiency is the share of the average sector level TFP that is explained by the resource allocation in the industry, i.e. the ratio between the cross term on the right hand side of equation (7) and the term on the left hand side. Panel B of Figure 19 shows this measure of allocative efficiency for the five economic sectors and the year 2017. In the textile, leather and footwear industry, where tariffs and NTMs have a combined level of protection of around $60 \%$, the allocation of resources across firms only explains $4 \%$ of average sectoral productivity, which is much lower than the $24 \%$ in the less protected metals industry. This indicates that in the textile, leather and footwear sectors, resources are trapped in low-productivity firms. Moreover, Panel A of Figure 19 shows that sectors with higher trade protection are also characterised by a larger dispersion of total factor productivity across firms, suggesting the co-existence of many low-productivity firms with more productive ones in the more protected sectors.

A final analysis looks for correlations between firm productivity and other firm characteristics as identified from the World Bank Enterprise Survey. The following simple OLS regressions of firm TFP on covariates are conducted on the pooled sample of firms using robust $\mathrm{SE}$ :

$$
\log \left(T F P_{f, t, k}\right)=\alpha_{0}+\alpha_{1} z_{f, t, k}+\boldsymbol{x}_{f, t, k}^{\prime} \boldsymbol{\beta}+\gamma_{k}+\delta_{t}+u_{f, t, k}
$$

for firm $\mathrm{f}$ in year $\mathrm{t}$ and economic sector $\mathrm{k}$. The variable $\mathrm{z}$ stands for the variable of interest, with a separate specification estimated for each variable of interest as presented in Table A.2. All specifications include the following covariates in the vector $\mathrm{x}$ : binary variables for the firm being a subsidiary, partly foreign owned or partly government owned, binary variables for the economic region the firm is located, the age of the firm, and three binary variables for firm size (based on employment, using 5, 20 and 100 as thresholds). All specifications also include sector and year fixed effects $\left(\gamma_{\mathrm{k}} ; \delta_{\mathrm{t}}\right)$. Including firm fixed effects was not possible due to the limited sample size. Selected results are shown in Table A.2 and Table A.3. 
Annex Table A.2. The productivity of firms depends on skills, international integration, innovation, access to credit, infrastructure and the regulatory environment

Correlates of firm's total factor productivity for Argentinian firms

\begin{tabular}{lcc}
\hline \multicolumn{1}{c}{ Independent Variable } & $\begin{array}{c}\text { Association with firm } \\
\text { level TFP }\end{array}$ & $\begin{array}{c}\text { Percentage increase/decrease } \\
\text { of TFP }\end{array}$ \\
\hline \multicolumn{1}{c}{ Skills } & + & $0.02 \%$ \\
\hline Percentage of workers that completed high school & ++ & $1.9 \%$ \\
Firm has formal training programs for workers & +++ & $0.1 \%$ \\
Trade & ++ & $0.03 \%$ \\
\hline Share of direct exports in total sales & ++ & $2.1 \%$ \\
Share of imported intermediate inputs & & \\
Firm has internationally recognized quality certification & & $1.6 \%$ \\
for its products & ++ & $2.3 \%$ \\
Innovation & ++ & $2.4 \%$ \\
\hline R\&D expenditure (in Million Pesos) & ++ & $-0.7 \%$ \\
Using technology licensed by a foreign company & & $1.8 \%$ \\
Firm has its own website & -- & \\
Access to Credit & ++ & $-0.6 \%$ \\
\hline Access to finance is an issue for the firm & & $-0.3 \%$ \\
Firm has a line of credit from a financial institution & -- & $-1.0 \%$ \\
Infrastructure & -- & $-0.9 \%$ \\
\hline Transport infrastructure is an issue for the firm & & \\
\hline Number of electricity outages per month & -- & -- \\
Regulatory Environment & & \\
\hline Labour regulation are an issue for the firm & & \\
Competitors from the informal sector are an issue for & & \\
the firm & & \\
\hline
\end{tabular}

Note: Results are based on OLS regressions on the pooled sample of firms using robust SE. The dependent variable is log of firm productivity (TFP). All regressions control for dummies for the firm being a subsidiary, partly foreign owned, partly government owned, dummies for the economic region the firm is located, the age of the firm, three dummies for firm size (based on employment, using 5, 20 and 100 as thresholds), dummies for the year of the observation as well as industry dummies. The sign "+" stands for a positive correlation and the sign "-" for a negative correlation of the independent variable with firms TFP. "+++" significant at the $1 \%$ level, "++"/"--" stands for significant at the $5 \%$ level and "+"" -" stands for significant at the $10 \%$ level

Source: OECD calculations based on the World Bank Enterprise Survey 2006. 2010 and 2017.

\section{Annex Table A.3. Correlates of firm's total factor productivity for Argentinian firms}

Coefficients for all control variables used in the OLS regressions in Table A.2

\begin{tabular}{lcc}
\hline & $(1)$ & $(2)$ \\
\hline & & \\
\hline Dependent Variable: & Log of firm level TFP \\
\hline Dummy variable for owning a license to use technology from a foreign firm & $0.023^{\star *}$ & $0.022^{* *}$ \\
& $(0.010)$ & $(0.010)$ \\
Dummy variable for the firm being a subsidiary of a larger company & $0.022^{\star *}$ & $0.023^{\star * *}$ \\
& $(0.009)$ & $(0.009)$ \\
Dummy variable for the firm being partly foreign owned & $0.000^{* * *}$ & $0.000^{* * *}$ \\
& $(0.000)$ & $(0.000)$ \\
Dummy variable for the firm being partly government owned & $0.074^{* * *}$ & $0.081^{* * *}$ \\
& $(0.010)$ & $(0.011)$ \\
Age of the firm (in years) & 0.0002 & 0.0002 \\
\hline
\end{tabular}




\begin{tabular}{|c|c|c|}
\hline & $(0.000)$ & $(0.000)$ \\
\hline Dummy variable for the firm being small (5-20 employees) & $\begin{array}{c}0.077 \\
(0.057)\end{array}$ & $\begin{array}{c}0.072 \\
(0.061)\end{array}$ \\
\hline Dummy variable for the firm being medium size (20-100 employees) & $\begin{array}{c}0.097^{*} \\
(0.057)\end{array}$ & $\begin{array}{c}0.090 \\
(0.061)\end{array}$ \\
\hline Dummy variable for the firm being large (more than 100 employees) & $\begin{array}{c}0.101^{*} \\
(0.057)\end{array}$ & $\begin{array}{c}0.092 \\
(0.062)\end{array}$ \\
\hline Share of direct exports in total sales (in \%) & & $0.0005^{* * *}$ \\
\hline & & $(0.000)$ \\
\hline Share of imported intermediate inputs (in \%) & & $0.0003^{*}$ \\
\hline & & $(0.000)$ \\
\hline Dummy variable for the firm being located in Rosario province (Buenos Aires is base category) & $\begin{array}{c}0.001 \\
(0.014)\end{array}$ & $\begin{array}{c}0.005 \\
(0.014)\end{array}$ \\
\hline Dummy variable for the firm being located in Mendoza province (Buenos Aires is base category) & $\begin{array}{l}-0.024^{*} \\
(0.014)\end{array}$ & $\begin{array}{c}-0.033^{* *} \\
(0.014)\end{array}$ \\
\hline Dummy variable for the firm being located in Cordoba province (Buenos Aires is base category) & $\begin{array}{l}-0.033^{* *} \\
(0.015)\end{array}$ & $\begin{array}{l}-0.029^{*} \\
(0.015)\end{array}$ \\
\hline Dummy variable for the firm being located in Tucuman province (Buenos Aires is base category) & $\begin{array}{l}-0.040 \\
(0.035)\end{array}$ & $\begin{array}{l}-0.037 \\
(0.035)\end{array}$ \\
\hline Sector fixed effects & Yes & Yes \\
\hline Year fixed effects & Yes & Yes \\
\hline Observations & 994 & 987 \\
\hline R-squared & 0.088 & 0.098 \\
\hline Adjusted R-squared & 0.0689 & 0.0773 \\
\hline
\end{tabular}

Note: Results are based on OLS regressions on the pooled sample of firms using robust SE. The dependent variable is log of firm productivity (TFP). All regressions control for dummies for the firm being a subsidiary, partly foreign owned, partly government owned, dummies for the economic region the firm is located, the age of the firm, three dummies for firm size (based on employment, using 5, 20 and 100 as thresholds), dummies for the year of the observation as well as economic sector dummies. In column 2, the specification includes in addition the share of direct exports in total sales as well as the share of imported intermediate inputs. Robust standard errors in parenthesis, $* * * \mathrm{p}<0.01, * * \mathrm{p}<0.05, * \mathrm{p}<0.1$.

Source: OECD calculations based on the World Bank Enterprise Survey 2006, 2010 and 2017.

\section{References:}

Caves, D.W., L, R.Christensen, and W. E, Diewert (1982), "The Economic Theory of Index Numbers and the Measurement of Input, Output, and Productivity", Econometrica, Vol. 50, No. 6 (Nov., 1982), pp. 1393-1414.

Levinsohn, J. and A. Petrin (2003), "Estimating Production Functions Using Inputs to Control for Unobservables", The Review of Economic Studies, Vol. 70, No. 2 (Apr., 2003), pp. 317-341.

Olley, S and A. Pakes (1996), "The Dynamics of Productivity in the Telecommunications Equipment Industry,” Econometrica, 64, pp. 1263-1298.

\section{Annex A.4. The OECD METRO model}

To analyse the economy wide effects of trade policy changes, computable general equilibrium models (CGE) combine the supply and the demand side of an economy. The OECD METRO model is a CGE model linking 61 countries and 57 economic sectors. It has been widely used in trade analysis to simulate the effects of domestic trade policy reforms in an international environment (OECD 2015). The simulations represent mediumterm shocks where production factors are mobile, but there is no capital accumulation.

CGE models rely on a comprehensive specification of all economic activity within and between countries (and the different inter-linkages that tie these together) and are suitable 
for examining the impact of a wide range of different trade shocks. The METRO model builds on the GLOBE model developed by McDonald and Thierfelder (2013). The novelty and strength of the METRO model lies in the detailed trade structure and the differentiation of commodities by end use. Specifically, commodities and thus trade flows, are distinguished by end use category, as those designed for intermediate use, for use by households, for government consumption, and as investment commodities.

The underlying framework of METRO consists of a series of individually specified economies interlinked through trade relationships. As is common in CGE models, the price system in the model is linearly homogeneous, with a focus on relative, not absolute, price changes. Each region has its own numéraire, typically the consumer price index, and a nominal exchange rate (an exchange rate index of reference regions serves as model numéraire). Prices between regions change relative to the reference region.

The database of the model relies on the GTAP v9 database (Aguiar et al 2016) in combination with the OECD Trade in Value Added data. Policy information combines tariff and tax information from GTAP with OECD estimates of non-tariff measures on goods, trade facilitation and export restricting measures. The dataset contains 61 countries and regional aggregates and 57 commodities.

The model is firmly rooted in microeconomic theory, with firms maximising profits and creating output from primary inputs (i.e. land, natural resources, labour and capital), which are combined using constant elasticity of substitution (CES) technology, and intermediate inputs in fixed shares (Leontief technology). Households are assumed to maximise utility subject to a Stone-Geary utility function, which allows for the inclusion of a subsistence level of consumption. All commodity and activity taxes are expressed as ad valorem tax rates, and taxes are the only income source of the government. In this study, the government is assumed to maintain an internal balance by adjusting its expenditure. At the same time, the trade balance is fixed, and the nominal exchange rate is flexible in the simulations. Wages and the remuneration rates of all other factors (land, capital, natural resources) are assumed to adjust to equilibrate the factor markets.

For this survey, the OECD Metro model is used to simulate a unilateral decrease of Argentina's currently applied tariffs to the lowest levels among G20 countries. 
Annex Table A.4. Unilateral tariff cuts would decrease input prices in many industries

Changes in sectoral input costs and import prices in reaction to a unilateral tariff cut (in \%).

\begin{tabular}{lcc}
\hline & Total Intermediate Input Cost & Intermediates Import Price \\
\hline Cereal grains & -0.1 & 1.7 \\
Other agriculture & 0.4 & 0.2 \\
Oil seeds & -0.3 & 0.8 \\
Dairy & 0.3 & -3.1 \\
Natural resources & 0.0 & 1.0 \\
Meats & 0.9 & 0.5 \\
Food and beverage & 0.4 & -4.1 \\
Textile and wearing apparel & -4.2 & -10.7 \\
Mineral products & 0.0 & -3.8 \\
Ferrous metals & -0.6 & -3.8 \\
Nonferrous metals & -0.4 & -2.5 \\
Metal products & -0.8 & -6.5 \\
Motor vehicles and parts & -3.7 & -8.9 \\
Transport equipment & -2.6 & 4.0 \\
Electronic equipment & -2.3 & -1.1 \\
Machinery and equipment & -1.2 & -4.1 \\
Other manufacturing & -0.4 & -2.9 \\
Transportation & -0.5 & 1.7 \\
Communication & 0.3 & 1.7 \\
Financial services & 0.2 & 1.6 \\
Insurance & 0.3 & 1.7 \\
Business services & -0.1 & 1.6 \\
Other services & -0.1 & 1.6 \\
\hline
\end{tabular}

Note: The results show the percentage change in sectoral input costs and import prices in reaction to a unilateral tariff cut in all natural resource and manufacturing sectors to the lowest levels among G20 countries.

Source: OECD calculations based on the OECD Metro model. 
Annex Table A.5. Unilateral tariff cuts would lead to sectoral reallocation of workers

Changes in sectoral employment by occupation group in reaction to a unilateral tariff cut (in \%).

\begin{tabular}{lccccc}
\hline & $\begin{array}{c}\text { Technical } \\
\text { and assistant } \\
\text { professionals }\end{array}$ & Clerks & $\begin{array}{c}\text { Service and } \\
\text { shop } \\
\text { assistants }\end{array}$ & $\begin{array}{c}\text { Office } \\
\text { managers } \\
\text { and } \\
\text { professionals }\end{array}$ & $\begin{array}{c}\text { Agricultural } \\
\text { and other low } \\
\text { skilled } \\
\text { workers }\end{array}$ \\
\hline Cereal grains & 2.8 & 2.3 & 2.8 & 3.2 & 2.6 \\
\hline Other agriculture & 1.1 & 0.8 & 1.1 & 1.0 & 0.8 \\
Oil seeds & 1.9 & 1.6 & 2.3 & 2.2 & 2.0 \\
Dairy & 1.4 & 1.2 & 1.5 & 1.0 & 1.3 \\
Natural resources & 1.3 & 1.2 & 1.6 & 1.3 & 1.2 \\
Meats & 0.8 & 0.6 & 0.9 & 1.0 & 0.7 \\
Food and beverage & 1.8 & 1.6 & 1.9 & 1.8 & 1.6 \\
Textile and wearing apparel & -3.3 & -3.5 & -3.2 & -3.1 & -3.5 \\
\hline Mineral products & -0.3 & -0.5 & -0.2 & -0.3 & -0.5 \\
Ferrous metals & 0.7 & 0.6 & 0.9 & 0.7 & 0.6 \\
Nonferrous metals & 7.4 & 7.2 & 7.6 & 7.5 & 7.3 \\
Metal products & -2.3 & -2.5 & -2.2 & -2.3 & -2.4 \\
Motor vehicles and parts & 7.7 & 7.5 & 7.9 & 7.6 & 7.5 \\
Transport equipment & -1.3 & -1.6 & -1.2 & -1.4 & -1.5 \\
Electronic equipment & -2.3 & -2.6 & -2.0 & -1.8 & -2.4 \\
\hline Machinery and equipment & -2.6 & -2.8 & -2.4 & -2.6 & -2.7 \\
\hline Other manufacturing & 0.2 & 0.0 & 0.3 & 0.2 & 0.0 \\
Transportation & 1.2 & 0.9 & 1.3 & 1.1 & 1.0 \\
Communication & 0.8 & 0.6 & 0.9 & 0.8 & 0.6 \\
Financial services & 0.7 & 0.5 & 0.8 & 0.7 & 0.7 \\
Insurance & 0.7 & 0.7 & 0.9 & 0.8 & 0.0 \\
\hline Business services & 1.0 & 0.7 & 1.1 & 1.0 & 0.8 \\
Other services & -0.3 & -0.5 & -0.2 & -0.3 & -0.5 \\
\hline & & & & & \\
\hline
\end{tabular}

Note: The results show the percentage change in sectoral employment by occupation group in reaction to a unilateral tariff cut in all natural resource and manufacturing sectors to the lowest levels among G20 countries. Source: OECD calculations based on the OECD Metro model.

\section{References}

Aguiar, A., B. Narayanan and R. McDougall (2016), "An Overview of the GTAP 9 Data Base", Journal of Global Economic Analysis, No. 1, pages 181-208, June.

McDonald, S. and K.E. Thierfelder (2013), Globe v2: A SAM Based Global CGE Model using GTAP Data, Model documentation. Available at: http://www.cgemod.org.uk/

OECD (2015), “METRO v1 Model Documentation”, TAD/TC/WP(2014)24/FINAL.

\section{Annex A.5. The effects of import protection on foreign direct investment}

To investigate the nature of FDI flows in Argentina, this study uses data on FDI inflows by economic sector for the years 2005 until 2017 from the Central Bank of Argentina (BCRA) as well as OECD data on average import tariffs by sector and year for Argentina. A panel dataset spanning the period 2005 to 2017 includes 16 manufacturing and 2 natural resource sectors, as import tariff data does not exist for services sectors.

To analyse how changes in sectoral import tariffs have been affecting FDI inflows in Argentina, the following OLS regression is estimated: 


$$
\log \left(\text { FDIinflow }_{i, t}\right)=\beta \text { tariff } f_{i, t}+\gamma_{i}+\delta_{t}+u_{i, t}
$$

For economic sector $\mathrm{i}$ and year $\mathrm{t}$. The independent variable of interest is the average import tariff for the sector (tariff). Fixed effects for the sector $\left(\gamma_{\mathrm{i}}\right)$ control for all unobservable time invariant sector specific characteristics and time fixed effects $\left(\delta_{t}\right)$ for all macroeconomic effects that affect all economic sectors a like. Robust standard errors are used to account for heteroscedasticity. In additional specifications, the sectoral import tariff is lagged one year.

The results suggest that FDI inflows into specific sectors in Argentina have tended to increase in reaction to higher import protection since 2005 (Table A.6). This indicates that foreign direct investment flows to Argentina have been attracted by the domestic market rather than internationally competitive production conditions.

\section{Annex Table A.6. FDI Flows are oriented to the domestic market}

Regressions of sectoral FDI inflows on sectoral tariffs

\begin{tabular}{lcr}
\hline \multicolumn{3}{c}{ Dependent variable: Inflows of foreign direct investment (in Million USD) } \\
\hline & $(1)$ & $(2)$ \\
Average applied sectoral tariffs (t-1) & $74.416^{\star *}$ & $(29.107)$ \\
& & $68.195^{\star *}$ \\
Average applied sectoral tariffs (t) & $(28.649)$ & Yes \\
Year Fixed Effects & Yes & Yes \\
Sector Fixed Effects & Yes & 216 \\
Observations & 216 & 0.182 \\
R-squared & 0.188 & \\
\hline
\end{tabular}

Note: Results are based on OLS regressions of FDI inflows on the average sectoral import tariffs (in the same or the previous period) and include fixed effects for the economic sector and the year of the observation. Robust standard errors in parentheses, *** $\mathrm{p}<0.01$, ** $\mathrm{p}<0.05, * \mathrm{p}<0.1$.

Source: OECD calculations based on tariff data from OECD and data on FDI inflows from BCRA. 